\title{
The Death of Copyright: Digital Technology, Private Copying, and the Digital Millennium Copyright Act
}

Glynn S. Lunney Jr

Texas A\&M University School of Law, glunney@law.tamu.edu

Follow this and additional works at: https://scholarship.law.tamu.edu/facscholar

Part of the Law Commons

\section{Recommended Citation}

Glynn S. Lunney Jr, The Death of Copyright: Digital Technology, Private Copying, and the Digital Millennium Copyright Act, 87 Va. L. Rev. 813 (2001).

Available at: https://scholarship.law.tamu.edu/facscholar/468

This Article is brought to you for free and open access by Texas A\&M Law Scholarship. It has been accepted for inclusion in Faculty Scholarship by an authorized administrator of Texas A\&M Law Scholarship. For more information, please contact aretteen@law.tamu.edu. 


\section{VIRGINIA LAW REVIEW}

\begin{tabular}{lll}
\hline VOLUME 87 & SEPTEMBER 2001 & NUMBER 5 \\
\hline
\end{tabular}

\section{ARTICLE}

THE DEATH OF COPYRIGHT: DIGITAL TECHNOLOGY, PRIVATE COPYING, AND THE DIGITAL MILLENNIUM COPYRIGHT ACT

\section{Glynn S. Lunney, Jr.}

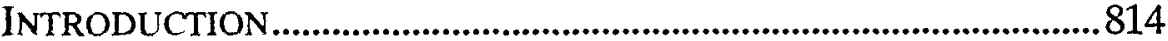

I. THE DMCA's TECHNOLOGICAL FIX..........................................823

A. The Road to the DMCA: Copyright as Anachronism...........823

$B$. Interpreting the DMCA's Anti-Circumvention Provisions:

A Search for the Public Interest............................................... 830

II. ADDRESSING THE RISK OF WIDESPREAD PRIVATE COPYING

WITHOUT BETRAYING THE PUBLIC INTEREST ............................8.845

A. A Modified Encryption-Based Approach .............................. 845

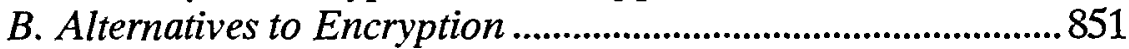

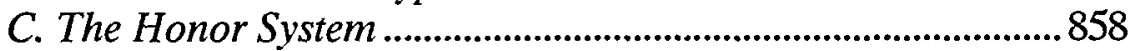

III. PRIVATE COPYING AND THE PUBlic INTEREST ........................869

A. Protection, Excess Incentives, and the Margins of Creativity.

"C.J. Morrow Research Professor of Law, Tulane University School of Law (glunney@law.tulane.edu). J.D., Stanford Law School. I would like to thank Tom W. Bell, Bob Brauneis, Victor Cook, Robert Denicola, Mark Lemley, Mike Madison, Mike Meurer, and Pam Samuelson for their helpful comments and suggestions, Rebecca Asta and Shandra Kotzun for their tireless efforts as my research assistants, participants at a faculty colloquium at the University of Cincinnati College of Law, and my wife, Leslie, without whom this article would not have been possible. I would also like to thank Ted Shapiro of the Motion Picture Association of America and Michael Sandt of GEMA for their assistance on particular aspects of the European levy system. As always, the final work and any errors remain my responsibility. 
B. Copyright's Capture: The Political Economy of Copyright and the Need for Civil Disobedience.........................................893

IV. THE ALTERNATIVES REVISITED ...........................................9910 CONCLUSION: PREPARING COPYRIGHT FOR THE DIGITAL

MILLENNIUM 918

\section{INTRODUCTION}

O

OPYRIGHT is dead. ${ }^{1}$ The Digital Millennium Copyright Act ("DMCA") ${ }^{2}$ has killed it. This does not mean that copyright has or will become irrelevant to the protection of creative works in this country. To the contrary, the exclusive rights set forth in Title 17 of the United States Code ${ }^{3}$ will continue to provide an important source of protection for works of authorship. The term "copyright," however, means more than a system of protecting creative works against unauthorized copying. Copyright signifies a system of protection designed and intended primarily to serve the public interest in the creation and dissemination of creative works, rather than the private interest of enriching those who create and disseminate such works. ${ }^{4}$ Where the first is copyright, the second is mere guild monopoly. With the enactinent of the DMCA, there is a very real danger that our system of protecting creative works will

${ }^{1}$ The title is an allusion to Grant Gilmore's book The Death of Contract (1974). For a listing of other articles and essays that have used variations on Professor Gilmore's title, see Robert C. Denicola, Mostly Dead? Copyright Law in the New Millennium, 47 J. Copyright Soc'y 193, 193-94 nn.1-12 (2000).

${ }^{2}$ Digital Millennium Copyright Act, Pub. L. No. 105-304, 112 Stat. 2860 (1998) (codified in scattered sections of 17 U.S.C., 28 U.S.C., \& 35 U.S.C.).

317 U.S.C.A. \$\$ 101-1332 (West 1996 \& Supp. 2000).

${ }^{4}$ United States v. Paramount Pictures, 334 U.S. 131, 158 (1948) ("The copyright law, like the patent statutes, makes reward to the owner a secondary consideration."); see also Feist Publ'ns v. Rural Tel. Serv. Co., 499 U.S. 340, 349 (1991) ("The primary objective of copyright is not to reward the labor of authors, but ' $[t]$ o promote the Progress of Science and useful Arts."') (quoting U.S. Const. art. I, § 8, cl. 8); Twentieth Century Music Corp. v. Aiken, 422 U.S. 151, 156 (1975) ("The immediate effect of our copyright law is to secure a fair return for an 'author's' creative labor. But the ultimate aim is, by this incentive, to stimulate artistic creativity for the general public good."); Mazer v. Stein, 347 U.S. 201, 219 (1954) ("The economic philosophy behind the clause empowering Congress to grant patents and copyrights is the conviction that encouragement of individual effort by personal gain is the best way to advance public welfare through the talents of authors and inventors in 'Science and useful Arts."') (quoting U.S. Const. art. I, § 8, cl. 8). 
serve primarily private interests. If so, then the protection of creative works will have come full circle, from the guild monopoly of the Stationers' Company to the guild monopoly of the DMCA, and copyright, in the sense of protection intended primarily to serve the public interest, will surely have died.

During the Anglo-American legal system's last experience with guild monopoly, the Stationers' Company of London controlled almost exclusively the publication of written works in England from 1556 to 1694 . As one might expect, and as courts from time to time remind us, the Stationers' Company did not always, or even usually, exercise its control over printing in a bemign manner designed to advance the pubhic welfare as a whole. ${ }^{6}$ To the contrary, securing the profits of a favored few within the guild seemed to be the Stationers' Company's guiding principle. ${ }^{7}$ In the end, the English Parliament was persuaded by the Company's excesses to refuse to renew the last of the Licensing Acts through which the Company had maintained its power. ${ }^{8} \mathrm{~A}$ decade and a half later, those same excesses led the English Parhament to replace guild control witl the first copyriglit statute, found in the 1709 Statute of Anne.'

The move from guild control to copyright was not merely a shift from one means of protecting written works to another. Rather, it was a more fundamental transformation. Where guild control sought protection to secure the private welfare of the guild meinbers, copyright sought protection to secure the public welfare more generally. To be sure, there is some overlap in these two purposes.

'J.B. Richardson, The Law of Copyright 5-14 (1913).

"See Lasercomb Am. v. Reynolds, 911 F.2d 970, 974 (4th Cir. 1990) (recognizing the role of the Stationers' Company in enabling "censorship of Protestant materials"); Alfred Bell \& Co. v. Catalda Fine Arts, 191 F.2d 99, 100 n.3 (2d Cir. 1951) (contrasting the commercial monopoly of the Stationers' Company with copyrights "granted to encourage learning or for the benefit of authors") (quoting 1 Stephen P. Ladas. The International Protection of Literary and Artistic Property 15 (1938)).

'See Harry Ransom, The First Copyright Statute 41-43, 55-57 (1956); Richardson, supra note 5, at 6 ("During the reign of Queen Elizabeth the granting of patents to print books was greatly abused, often extending to the sole right to print all books of a particular class.... These patents pressed so hard on the poorer printers that obtaining no redress by petitions to the Queen, they began to print in defiance both of the Queen's patents, and also of the laws of the Company.").

"See Richardson, supra note 5, at 13-14; Mark Rose, Authors and Owners: The Invention of Copyright 33 (1993).

8 Ann., c. 19 (1709) (Eng.). 
A protection scheme designed to secure the public's access to a wide variety of creative works will almost certainly lead to an incidental mcrease in revenue for those who produce such works. Similarly, a protection scheme designed to maximize producer revenue will almost certainly lead to an incidental increase in the variety of works available to the public. In the end, however, one of these purposes must predominate, and the choice between them creates a fundamental divide between guild monopoly and copyright.

At every level, a comparison of the protection available under the Stationers' Company and the protection offered by the Statute of Anne reflects this divide. Where the Stationers' Company extended protection to every work, even those created in the distant past, ${ }^{10}$ the Statute of Anne extended protection only to newly created works. ${ }^{11}$ Where the Stationers' Company extended protection indefinitely, ${ }^{12}$ the Statute of Anne granted protection only for a limited time. ${ }^{13}$ Where the Stationers' Company established its own rules defining the scope of protection accorded any given work, ${ }^{14}$

${ }^{\text {to }}$ Mark Rose, for example, has reprinted a letter from John Locke to Edward Clark in which Locke asserted:

[t] hat any person or company should have patents for the sole printing of ancient authors is very unreasonable and injurious to learning; and for those who purchase copies from authors that now live and write, it may be reasonable to limit their property to a certain nnmber of years after the death of the author, or the first printing of the book, as, suppose, fifty or seventy years. This I am sure, it is very absurd and ridiculous that any one now living should pretend to have a propriety in ... any copy or writings of authors who lived before printing was known or used in Europe.

Rose, supra note 8, at 33; see also Paul Goldstein, Copyright's Highway: From Gutenberg to the Celestial Jukebox 41 (1994) ("The Stationers' rights were perpetual, passing from one generation of printers to the next.").

${ }^{11}$ Actually, the Statute of Anne contamed a grandfathering provision that extended protection for twenty-one years to books already printed. 8 Ann., c. 19, \&1 (1709) (Eng.).

${ }^{12}$ E.g., L. Ray Patterson, Understanding the Copyright Clause, 47 J. Copyright Soc'y 365, 378 (2000).

$13 \&$ Ann., c. 19, §\$1, 11 (1709) (Eng.) (providimg for fourteen-year tern with a renewal term of fonrteen years).

${ }^{14}$ Augustine Birrell, The Law and History of Copyright in Books 77-81 (photo. reprint 1971) (1899) (noting the Company's use of its by-laws to control the effective scope of protection for particular works); Richardson, supra note 5, at 6 ("By their charter [the Stationers' Coinpany] were einpowered to make bye-laws binding on their members, and the art or mystery of printing in England was strictly confined to their body."); Patterson, supra note 12, at 378 \& n.33 (noting "the Stationers' 
the Statute of Anne entrusted the right to define the scope of protection to a largely impartial judiciary. ${ }^{15}$ In its Preamble to the Statute of Anne, the English Parliament summarized these changes by boldly proclaiming a new purpose for protecting creative works: "the encouragement of learning.",16 No longer would the protection of creative works serve primarily the printing guild's private interests. Instead, protection would serve primarily to advance general social welfare.

Seventy-eight years later, James Madison enshrined this public purpose in Article I, Section 8, Clause 8 of the United States Constitution, empowering Congress to enact copyright and patent statutes "[t]o promote the Progress of Science and useful Arts."17 As the Supreme Court has recognized on a number of occasions, this Clause contains both a grant and a limitation on congressional power. ${ }^{18}$ Congress may enact a copyriglit statute, but only if, and to the extent that, it serves the public, and not merely a private, interest. Following the lead England set in the Statute of Anne, the first United States copyriglit statute, enacted in 1790, extended protection only to newly created works, and provided that protection for only a limited tinne. ${ }^{19}$ It also made the judiciary, and not the publishers, the ultimate arbiters of copyright's proper scope..$^{20}$ In its title, the first United States copyright statute proclaimed its public purpose: "An act for the encouragement of learning."

Company had the power of self-governance and the authority to enact ordinances" "to serve their ends").

" 8 Ann., c. $19, \$ 1$ (1709) (Eng.).

in Id. at pmbl.

" U.S. Const. art. I, \$ 8, cl. 8; see also Robert Patrick Merges \& Glenn Harlan Reynolds, The Proper Scope of the Copyright and Patent Power, 37 Harv. J. on Legis. 45, 56-57 (2000) (discussing the Framers' general distaste for monopolies that do not advance the public interest).

${ }^{*}$ See, e.g., Graham v. John Deere Co., 383 U.S. 1, 5 (1966); see also Feist Publ'ns v. Rural Tel. Serv. Co., 499 U.S. 340, 346-47 (1991) (discussing Congress's power to enact copyright laws under the Constitution); Yochai Benkler, Constitutional Bounds of Database Protection: The Role of Judicial Review in the Creation and Definition of Private Rights in Information, 15 Berkeley Tech. L.J. 535, 539-52 (2000) (surveying the Court's decisions on this point).

${ }^{14}$ Act of May 31, 1790, ch. 15, $\$ 1,1$ Stat. 124, 124.

${ }^{*}$ Id. $\$ 6$ (authorizing any copyright proprietor injured by unauthorized printing or publication of her work to recover damages "by a special action on the case founded upon this act, im any court having cognizance thereof").

"Id. at tit. 
For nearly three hundred years, the Statute of Anne and its successors have retained this public interest focus. Although the constant clamoring of copyright's propertied class has weakened the link between copyright and its original public purpose, several aspects of copyright law, including the originality requirement, the idea-expression dichotomy, and the fair use doctrine, have limited the scope and availability of copyright protection. These doctrines have helped ensure that copyright, while protecting works of authorship against infringement, has left room for future authorship and has limited the monopoly consequences that would follow from overbroad protection. These limitations on the availability and extent of copyright's protection have thereby helped ensure that copyright serves the public interest. Unfortunately, although these limitations have been prominent features of copyright since its birth in 1709, the DMCA may overturn these guardians of the public interest.

Driven by the widespread dispersion of the ability to inake nearperfect and inexpensive copies, the DMCA aims to replace copyright's traditional approach of direct legal action against each individual infringer with a technological lock effective against all would-be infringers. The DMCA clearly reflects congressional concern that, left unconstrained, digital technology would soon place the power to inake near-perfect and inexpensive copies into every hoine and office. ${ }^{2}$ This dispersion of copying technology creates the potential for widespread private copying, enabling ordinary consumers to copy a work for themselves rather than pay for an authorized copy. Although individually trivial, widespread private copying in the aggregate could radically reduce the incentive to create any given work of authorship. Moreover, in the face of widespread private copying, copyright's traditional approach of direct legal action against each individual infringer would likely

${ }_{22}$ H.R. Rep. No. 105-551, pt. 2, at 25 (1998) ("[T] he Committee also recognizes that the digital environment poses a unique threat to the rights of copyright owners, and as such, necessitates protection against devices that undermine copyright interests. In contrast to the analog experience, digital technology enables pirates to reproduce and distribute perfect copies of works-at virtually no cost at all to the pirate."); S. Rep. No. 105-190, at 8 (1998) ("Due to the ease with which digital works can be copied and distributed worldwide virtually instantaneously, copyright owners will hesitate to make their works readily available on the Internet without reasonable assurance that they will be protected against massive piracy."). 
prove ineffective. Lawsuits against each individual private copier would become prohibitively expensive and politically unwise. Digital technology therefore presents a potentially serious, and otherwise unchecked, threat to the incentives thought necessary to ensure a continuing supply of creative works.

Nevertheless, the DMCA goes too far in its efforts to eliminate the threat digital technology poses. In order to ensure that encryption and the other technological locks that copyright owners adopt are effective, the DMCA prohibits others from making, distributing, or importing the decryption technology that could serve to unlock encrypted works. The DMCA thereby restores to today's copyright owners the same combination of technological and legal control over the publication and dissemination of works enjoyed by the Stationers' Company more than three hundred years ago. During its reign, the Stationers' Company controlled unauthorized duplication of published works through the exclusive possession of printing presses backed by an English law that prohibited anyone other than a member of the Stationers' Company from operating a printing press. ${ }^{23}$ Proving that history can repeat itself, the anticircumvention provisions of the DMCA re-create almost precisely this same combination of technological control backed by legal prohibition. The only difference is a slight change in form: The legally controlled technology necessary to make unauthorized copies during the reign of the Stationers' Company was the printing press; today, the legally controlled tool needed to make unauthorized copies is the technology of decryption.

By prohibiting others from possessing the decryption tools necessary to break the technological locks that the copyright industry places on its digital works, the DMCA empowers those who produce digital works of authorship to set the terms of public access. The DMCA thereby creates a grave risk that today's publishers, like the Stationers' Company before them, may not exercise this power to advance the public welfare generally.

Recognizing this risk, Congress has incorporated language into the DMCA that might be read to permit fair or otherwise non-

${ }_{23}^{2}$ Richardson, supra note 5, at 5-6 (noting that under Charter of May 4, 1556, "the art or mystery of printing in England was strictly confined to" the Stationers' Company. which was "authorised to search for and destroy all prohibited books, and to imprison anyone exercising the art of printing contrary to their direction"). 
infringing uses of decryption technology. Courts, however, have so far shown little inclination to incorporate the fair use doctrine or other limitations on copyright protection into the seemingly absolute prohibitions of the DMCA. Even if they did, problems would remam. Dealing with decryption technology is difficult because the same decryption technology that enables the making of a noninfringing copy of a creative work also enables the inaking of an infringing copy. A decryption tool that enables a teacher to prepare a few spur-of-the-moment copies for the classroom is the same decryption tool that enables a pernicious pirate to duplicate the work for resale. Moreover, unless lawful access to decryption technology is severely restricted, the widespread dissemination of decryption technology is almost inevitable. Because decryption technology is usually readily portable and easily duplicated, it will likely prove impossible to contain. If every librarian, teacher, or researcher with a potential fair use claim is allowed to possess decryption technology, it will be all but impossible to keep the teclinology out of the hands of those who intend unlawful uses.

As a result, decryption presents something close to an all-ornothing choice. We can limit the lawful possession of the necessary decryption tools to a tiny few and thereby have a realistic chance of limiting the general availability of such tools. Such an approach, however, risks denying the necessary decryption technology to individuals intending an otherwise nominfringing use. Alternatively, we can permit easier access to decryption technology by allowing essentially anyone with a plausible claim to fair or lawful use of such technology to possess it. Yet this approach would risk allowing the decryption technology to spread and become a source of unauthorized copying more generally.

To address the risks of widespread private copying that digital technology creates, the DMCA prohibits essentially any lawful manufacture or distribution of the decryption tools necessary to break copyright owners' technological controls. ${ }^{24}$ The Librarian of Congress has recently reinforced this choice by limiting the class of works exempted from the DMCA's coverage to two: " 1 . Compilations consisting of lists of websites blocked by filtering software applications; and 2. Literary works ... protected by access control

${ }^{24}$ See infra text accompanying notes $49-99$. 
mechanisms that fail to permit access because of malfunction, damage or obsoleteness." 25 Although certain to restrict some fair or otherwise noninfringing uses, the DMCA's choice to limit almost altogether access to decryption technology may nevertheless prove the lesser evil given the dilemma that decryption technology presents.

Yet, there are two aspects of private copying that suggest a different solution. First, from an economic perspective, private copying may not threaten copyright's public purpose at all. If private copying increases as a work's popularity increases, then private copying will reduce revenue, assuming it does so at all, most substantially for the most popular works. Because such popular works typically receive an economic return far im excess of that necessary to ensure their creation, they may remain profitable even in the face of considerable private copying. At the same time, and again, to the extent that private copying increases with the popularity of a work, private copying may have little effect on the incentives for the less popular works at the inargins of copyright's production frontier. If so, then private copying, unlike traditional infringement, will not lead to a sub-optimal supply of creative works, but will only enable consumers to recapture a portion of the "excess" incentive otherwise available for the most popular works. As a result, Congress should not prohibit such private copying. Indeed, given the Constitution's pubhic interest mandate, Congress could not constitutionally prohibit such private copying.

Second, private copying, again unlike traditional infringement, represents a critical form of democratic self-governance: civil disobedience. Copyright laws have become increasingly unjust, and in the face of unjust laws, individual citizens have no choice but to disobey and thereby force society to enforce the law in a way that makes its injustice palpable. So long as copyright owners can isolate and brand as dangerous those involved in unauthorized copying, their transaction cost advantage in organizing to lobby for overbroad copyright protection gives them a distimct edge in the political process. But if they must seek enforcement directly

${ }^{2}$ Exemption to Prohibition on Circumvention of Copyright Protection Systems for Access Control Technologies, 65 Fed. Reg. 64,556, 64,574 (Oct. 27, 2000) (to be codified at 37 C.F.R. $\$ 201.40($ b) ) [heremafter Copyright Office, Final Rulemaking]. 
against a broad range of ordinary citizens, copyright owners' collective action advantage may prove insufficient to sustain overbroad protection. Copyright owners may be able to persuade authorities to imprison one MIT student in order to protect their economic wealth, ${ }^{26}$ but when they start labeling all college students, ${ }^{27}$ and the Girl Scouts too, ${ }^{28}$ as dangerous subversives, they may have more trouble persuading authorities to their point of view. Private copying, as a form of civil disobedience, can play a central role in reaching that point.

To explore these issues, Part I of this Article will begin with a brief history of copyright protection, exploring the historical path which led to the DMCA and examining the DMCA's anticircumvention provisions to see how they effectively eliminate some key limitations copyright has traditionally imposed on the protection of creative works. Part II will then examine alternatives to the DMCA to determine whether there is some other way to address the threat to incentives that the imcreased dispersion of copying technology creates, while still preserving a vital role for the overriding public interest copyright is supposed to serve. Given the potential all-or-nothing choice decryption technology presents,

${ }^{26}$ In the end, the student, David LaMacchia, was able to avoid prison time for his interference with the monopoly profits of copyright owners. United States v. LaMacchia, 871 F. Supp. 535, 545 (D. Mass. 1994). Although the requirement that he pay his attorneys' fees might be seen as sufficient punishment for Mr. LaMacchia's behavior, Congress amended the Copyright Act to ensure that anyone who repeats Mr. LaMacchia's conduct can be imprisoned. No Electronic Theft Act, Pub. L. No. 105-147, § 2(b), 111 Stat. 2678 (1997) (codified at 17 U.S.C. $\$ \$ 101,506,507$ (1994 \& Supp. V 2000) and 18 U.S.C. $\$ \$ 2319,2319 A, 2320$ (Supp. V 2000)).

${ }^{27}$ See, e.g., Lori Enos, RIAA Cracks Down on Net Pirates, E-Comnerce Times (Sept. 20, 2000), at http://www.newsfactor.com/perl/printer/4339.html (noting that "[o]ne group that the RIAA has in its crosshairs is college students who have easy access to computers and high-speed Internet connections through their schools").

${ }^{28}$ In the summer of 1996 , the American Society of Composers, Authors \& Publishers ("ASCAP") notified a number of Girl Scout camps that they could no longer sing copyrighted musical works around their summer campfires unless they paid a licensing fee. E.g., Lisa Bannon, Birds Sing, But Campers Can't-Unless They Pay Up, Star Tribune (Minneapolis), Aug. 24, 1996, at 10E, available at LEXIS, News Library, STRIB File. Although ASCAP quickly retracted its licensing demand after it received unfavorable publicity, e.g., Michael Davis, ASCAP Changes Tune on Camp Sing-Alongs, The Tennessean (Nashville), Aug. 28, 1996, at 1E, available at LEXIS, News Library, TENNES File, bills that would grant an exception for public performances at summer camps were introduced in the next legislative session. Fairness in Musical Licensing Act of 1997, H.R. 789, 105th Cong. \$ 2(d) (1997). 
Part III of this Article will consider some of the reasons why copyright protection that prohibits all unauthorized private copying is both unnecessary and undesirable. In the end, there may be no perfect solution to the problem of widely dispersed copymg technology and the consequential risk of widespread private copying. Part IV will nevertheless take a hard look at the issues with the goal of identifying steps that courts and Congress can take to ensure that the DMCA's technological control approach is harnessed for the public, not a private, interest. Otherwise, while protection of creative work may continue, copyright will be gone.

\section{THE DMCA'S TECHNOLOGICAL FIX}

\section{A. The Road to the DMCA: Copyright as Anachronism}

To understand how we have reached the point where the DMCA seemed necessary, we must start with copyright's origins in the early eighteenth century. At that tune, printing presses were large, expensive, and consequently few. As a result, printers could be found and policed with relative ease, and the principle of controlling unauthorized reproduction by direct action against individual infringing printers was both practical and sensible. Given this technological background, copyright statutes adopted an approacli to protecting creative works that relied principally on direct action against individual infringers. So firmly rooted was this approach that neither the Statute of Anne nor the Copyright Act of 1790 expressly incorporated liability for any action other than direct infringement. ${ }^{29}$ Indeed, the current United States copyright statute, more than two hundred years later, has yet to incorporate express liability for anything other than direct infringement. ${ }^{30}$

${ }^{24}$ Act of May 31, 1790, ch. 15, $\$ 6,1$ Stat. 124, 125 ("[A]ny person or persons who shall print or publish any manuscript, without the consent and approbation of the author or proprietor thereof, ... shall be liable ...."); 8 Ann., c. 19, \$1 (1709) (Eng.) (imposing liability on any bookseller who "shall print, reprint, or import, or cause to be printed, reprinted, or imported" any protected material).

"See Sony Corp. of Am. v. Universal City Studios, 464 U.S. 417, 434 (1984) ("The Copyright Act does not expressly render anyone liable for infringement committed by another."); see also 17 U.S.C. \$ 501(a) (Supp. V 2000) ("Anyone who violates any of the exclusive rights of the copyright owner as provided by Sections 106 through 121, 
Unfortunately, the advent of digital technology and the Internet has rendered this traditional approach of targeting individual infringers increasingly unworkable. The developinent of these technologies places the power of creating near-perfect digital copies in almost every hoine and on every desk. By dispersing the power to create copies, these technologies confound traditional copyright and stretch, if not break, the ability of copyright's traditional approach to protect creative works. As much for political reasons as for inore practical concerns, copyright owners cannot search the hard drives of each potential infringer (given that everyone with a computer qualifies) and bring suit against those discovered in possession of infringing copies. ${ }^{31}$ Moreover, in the eighteenth century, for infringement to prove attractive, a printer eventually had to sell the potentially infringing copies, allowing the illegal activity to come to light on its own. In contrast, with digital teclmology and the Internet, many infringements will remain private. By using a computer to inake an unauthorized copy, an individual can obtain her own copy of the work without paying the custoinary price. For that reason, private infringement can prove attractive without any need to resell the unauthorized copies, reducing the chance that private copying will come to light without intrusive searches.

To surmount the difficulties that the increasing dispersion of copying technology creates for copyright, copyright owners have resorted to a variety of stopgap measures to maintain copyright's effectiveness. For example, copyriglit owners have sought to establish the contributory or vicarious liability of a single party, sucli as Sony or Napster, who has made the individual infringements possible..$^{32}$ This approach creates a single liable party who can, in a

or of the author as provided in Section $106 \mathrm{~A}(\mathrm{a})$, or who imports copies or phonorecords into the United States in violation of Section 602 , is an infringer...."). The DMCA creates safe harbors for Internet Service Providers limiting their liability for vicarious or contributory infringement, but the DMCA does not itself create such hability. Id. \$ 512(a)-(e), (j).

${ }^{31}$ See; e.g., James Lardner, Fast Forward: Hollywood, the Japanese, and the Onslaught of the VCR 203-04 (1987) (recounting critical political commentary includimg depictions of "Video Pohce" invading private residences to search for infringing private copies following the Ninth Circuit's decision in the Sony Corp. case).

32 Sony Corp., 464 U.S. at 419-20; A\&M Records v. Napster, Inc., 239 F.3d 1004, 1010-11 (9th Cir. 2001). 
sense, stand in the shoes of the individually infringing printer traditionally targeted. Similarly, copyright owners have persuaded Congress to expand the availability of criminal penalties for copyright infringement. ${ }^{33}$ The increased availability of criminal penalties can help maintain copyright's effective level of deterrence by counterbalancing the substantially reduced risk of being caught that arises from the increased portability and dispersion of copying technology. ${ }^{34}$ Increased use of criminal penalties can also shift soine of the costs of enforcing copyright away from copyright owners and onto taxpayers.

There is a limit, however, to the ability of these measures to ensure the effectiveness of copyright's traditional approach in the face of the ongoing dispersion of copying technology. Current technology often uses a central registry, such as the ones found on Napster and MP3.coin, to facilitate the ability of individuals to locate the files available for copying. Such a central registry provides a convenient excuse for attempting to bring Napster and MP3.com within the reach of copyright's traditional direct action approach. ${ }^{35}$ Yet the next generation of copying technology, with programs such as Gnutella and FreeNet, enables peer-to-peer file sharing without the convenient target offered by a central registry. ${ }^{36}$ Moreover, as

"No Electronic Theft Act. Pub. L. No. 105-147, 111 Stat. 2678 (1997) (codified at 17 U.S.C. $\$ \$ 101,506,507$ (1994 \& Supp. V 2000) and 18 U.S.C. $\$ \$ 2319,2319$ A, 2320 (Supp. V 2000)) (removing the requirement that infringement be "for profit" before criminal penalties apply); see also Digital Theft Deterrence and Copyright Damages Improvement Act of 1999, Pub. L. No. 106-160, § 2, 113 Stat. 1774, 1774 (1999) (codified at 17 U.S.C. $\$ 504$ (c) (Supp. V 2000)) (increasing statutory damages available for infringement by fifty percent).

" Enos, supra note 27 ("Although [RIAA semior vice president and director of antipiracy Frank] Creighton said it would be 'unfortunate' if the OSU student [targeted by RIAA for criminal copyright infringement charges] ends up with a felony record for the rest of his life, he did say that such high-profile actions act as a deterrent to other would-be pirates.").

"See Napster, 239 F.3d at 1019-24 (affirming grant of preliminary injunction on the grounds that Napster was likely liable, both contributorily and vicariously, for acts of copyright infringement by its users); UMG Recordings v. MP3.com, 92 F. Supp. 2d $349,351-53$ (S.D.N.Y. 2000) (granting partial summary judgment for plaintiffs and rejecting the fair use defense asserted by defendant supplier of technology designed to allow owners of sound recordings to access them via the Internet from any location).

when a user requests a file through a decentralized peer-to-peer file sharing program, her computer will search for a title on, and then download the title froin, the other users' computers directly. Although Gnutella and FreeNet have received the 
these dispersed file-sharing programs come onlime, many of the remaining technical limitations on unauthorized copying, such as bandwidth restrictions, memory limitations, and the high cost of $\mathrm{CD}$ burners, will also fade. As a result, unauthorized sharing between private individuals through the Internet, which today is a relatively minor problem reaching only musical works, sound recordings, and certain computer programs, threatens to become a serious problem for digital works of authorship more generally.

At some point, the contimuing dispersion of copying technology will render the traditional enforcement approach of suing each individual infringer impractical. If there are thousands of infringers, it will simply cost too much to police their conduct effectively through individual judicial proceedings brought against each one. For copyright owners, the continuing dispersion of copying technology and the ineffectiveness of copyright's traditional approach in containing widespread private infringements give rise to a nightmare scenario im which only the first person who desires access to a work pays for it, and the rest obtain a perfect digital copy for free through sonie sort of file sharing technology. Some copyright owners have cautioned that, if left uncontrolled, digital technology niay destroy their creative industry altogether ${ }^{37} \mathrm{Al}-$ though this doomsday scenario resides more in rhetoric than reality, the increasing number of private copies has the potential to erode, perhaps substantially, the earnings associated with any given work.

Concerned with how far their earnings might drop, copyright owners have sought alternative fornis of protection. Producers of mass-market software for the personal computer have relied on both encryption and contractual use restrictions, misleadingly

most press, a variety of decentralized peer-to-peer file sharing programs are available for free from websites such as www.zeropaid.com and CNET's www.downloads.com. Most of these programs have names that are, as yet, unfamiliar, including Rapigator, $\mathrm{KaZaA}$, iMesh, and BearSliare. Siona LaFrance, Burn, Baby, Burn: No Napster? No Problem, New Orleans Times-Picayune, Mar. 22, 2001, at E1.

${ }^{37}$ E.g., National Information Infrastructure Copyright Protection Act of 1995: Hearing on S.1284 Before the Senate Coinm. on the Judiciary, 104th Cong. 11 (1996) (prepared statement of Kenneth R. Kay, Executive Director, Creative Incentive Coalition) ("In the [piracy-related Internet] sites we will tour today, one can read the blueprints for a massive structure of cyber-piracy that could blight the future of America's creators."). 
called licenses, to supplement copyright protection. ${ }^{3 s}$ Both strategies have undoubtedly helped, but neither is likely to solve the more general problem of digital copying on its own. Contractual use restrictions, absent widespread adoption of the Uniform Con1puter Information Transactions Act, remain of questionable legal enforceability. ${ }^{39}$ Even if legally enforceable, they are largely ineffective in controlling private copying. Like copyright law, contract law requires lawsuits against each individual breaching party. Using contract law to control private copying will therefore become prohibitively expensive as private copying becoines increasingly widespread.

In contrast, technological controls, such as encryption, can eliminate private copying without the need for individual lawsuits. Instead of the prohibitive transaction costs of identifying, suing, and then enforcing a judgment or settlement against each alleged infringer, the copyright owner can use encryption to incorporate a technological lock on the distributed copies of her work and thereby effectively preclude virtually all private copying. In a sense, technological controls reverse the dispersion of copying technology by eliminating the copying technology's ability to reproduce a work unless properly authorized.

When software companies first introduced technological controls in the mid-1980s, however, there were two problens. First, third parties quickly developed technological keys that would defeat the controls. These unauthorized keys were both inexpensive and widely available, and they reopened the door to private copying." Second, when software producers responded with more complicated encryption schemes or turned to encryption that relied on a physical key that could not be easily duplicated, third parties developed more advanced decryption keys and other ineans for de-

"E.g., Step-Saver Data Sys. v. Wyse Tech., 939 F.2d 91, 96 n.7 (3d Cir. 1991) (noting the computer software industry's development of licenses to avoid copyright's first sale doctrine); Vault Corp. v. Quaid Software Ltd., 847 F.2d 255, 261 n.13 (5th Cir. 1988) (noting the computer software industry's use of encryption to supplement copyright protection).

${ }^{39}$ Compare Step-Saver, 939 F.2d at 105-06 (finding a lack of effective consent to license terms and therefore refusing to enforce box-top license), with ProCD, Inc. v. Zeidenberg, 86 F.3d 1447, 1449, 1452-53 (7th Cir. 1996) (finding effective consent to license terms and therefore enforcing software license).

* Lardner, supra note 31, at 278. 
feating the protection. This development led to an escalating fight between encryption and decryption technologies that soon reached a point where the sort of encryption required to protect against available decryption technology rendered use of the protected program unwieldy and precluded many unobjectionable uses as well. ${ }^{41}$

Still looking for a solution, and having learned the futility of a purely private solution from watching the encryption-decryption battles over computer software, copyright owners turned to Congress. To ensure the effectiveness of technological controls on copying, copyright owners denanded that Congress prohibit thirdparty creation of the necessary decryption keys. Responding to their concerns, Congress first adopted such an approach in the Audio Hoine Recordimg Act of 1992 ("AHRA"). The AHRA represented a limited adoption of technological controls as it applied only to a single technology, "digital audio recording devices." Even with such a limited agenda, the AHRA was not entirely successful, given that, after the inclusion of the required technological controls, digital audiotape never achieved the commercial success originally expected. ${ }^{44}$ Despite this failure, Congress again embraced technological controls on unauthorized copying in the DMCA. This time, however, Congress did not limit technological controls to a particular technological development, but rather

${ }^{41}$ See generally Richard P. Adelstein \& Steven I. Peretz, The Competition of Technologies in Markets for Ideas: Copyright and Fair Use in Evolutionary Perspective, 5 Int'l Rev. L. \& Econ. 209, 213-14 (1985) ("The seller's attempt to discriminate between buyers and 'free riders' in this way provides the setting for an unceasing 'competition of technologies' between sellers and free riders. Just as sellers must call upon various physical and organizational technologies both to ease the free flow of information and goods between theinselves and willing buyers and to maintain effective exclusionary barriers to free riding, potential free riders are themselves induced to search out the technical means by which the exclusive relationship between buyer and seller can be penetrated for their own benefit.").

${ }^{42}$ Audio Home Recording Act of 1992, Pub. L. No. 102-563, 106 Stat. 4237 (1992) (codified at 17 U.S.C. $\$ \$ 1001-1010$ (1994 \& Supp. V 2000)).

${ }^{43} 17$ U.S.C. $\$ 1002$ (a), (c) (1994).

${ }^{4}$ E.g., Paul Veravanich, Rio Grande: The MP3 Showdown at Highnoon in Cyberspace, 10 Fordham Intell. Prop. Media \& Ent. L.J. 433, 451 (2000) ("Ironically, the DAT never became the success that most music industry observers assumed that it would."); A. Dustin Mets, Note, Did Congress Protect the Recording Industry into Competition? The Irony of the Digital Performance Right in Sound Recordings Act, 22 U. Dayton L. Rev. 371, 375 n.30 (1997) (noting that digital audio taping never gained widespread consumer acceptance). 
radically expanded coverage in an attempt to safeguard virtually all digitally-stored information. ${ }^{45}$

The DMCA einploys an overlapping approach to control both the use of and access to decryption technology in order to ensure the effectiveness of technological controls on unauthorized copying. First, in Section 1201(a)(1), the DMCA prohibits any person from circumventing "a technological ineasure that effectively controls access to a work protected under this title." ${ }^{46}$ Second, to avoid the need for a lawsuit against each individual using decryption to break a copyrighted work's technological lock, Sections 1201(a)(2) and 1201(b)(1) of the DMCA prohibit any person froin manufacturing, importing, offering to the public, providing, or otherwise trafficking in decryption technology that is primarily desigued to circumvent technological locks; has only a limited commerciallysignificant purpose other than to circumvent such a technological lock; or is marketed for use in circumventing such a technological lock. ${ }^{47}$ Third, in addition to these general provisions, the DMCA requires analog videocassette recorders manufactured or imported eighteen months after the enactinent of the DMCA to incorporate a specified forin of copy control technology.

On its own, the DMCA's resort to technological controls as a means of protecting creative works does not necessarily betray copyright's public purpose. The defining characteristic of copyright is not its traditional approach of targeting individual infringers. The direct action approach was merely a convenient form given the technology available when copyright was first developed. Rather, the defining characteristic of copyright - that which distinguishes it from guild monopoly-is that it protects creative works primarily to advance the public, rather than a private, interest. Copyright can evolve and yet remain true to its original public spirit. Unfortunately, the DMCA surrenders this broader public interest to the dictates of a private interest-the welfare of copyright owners. By

"See S. Rep. No. 105-190, at 2 (1998) ("With this constant evolution in technology, the law inust adapt in order to make digital networks safe places to disseminate and exploit copyrighted inaterials. The legislation implementing the treaties, Title I of this bill, provides this protection and creates the legal platform for launching the global digital on-line marketplace for copyrighted works.").

« 17 U.S.C. $\$ 1201$ (a)(1)(A) (Supp. V 2000).

${ }^{5}$ Id. $\$ 1201(\mathrm{a})(2)(\mathrm{A})-(\mathrm{C}),(\mathrm{b})(1)(\mathrm{A})-(\mathrm{C})$.

* Id. $\$ 1201(\mathrm{k})$. 
prohibiting the production and distribution of decryption technology, the DMCA enables copyright owners to use encryption as they see fit to protect their works. Although the DMCA contains some language aimed at preserving copyright's public interest perspective, the DMCA's general prohibitions may leave too little room for otherwise lawful and fair uses of decryption technology. The next Section therefore examines the DMCA's anticircumvention provisions to determine whether they contain adequate safeguards of the public interest.

\section{B. Interpreting the DMCA's Anti-Circumvention Provisions: $A$ Search for the Public Interest}

At the heart of the DMCA lies Section 1201(a). It contaims two subsections designed to enable copyright owners to use encryption or other technological measures to control access to their works. In Section 1201(a)(1), the DMCA prohibits individuals from circuinventing "a technological measure that effectively controls access to a work protected under this title." ${ }^{199}$ In Section 1201(a)(2), the DMCA prohibits the manufacture, importation, and distribution of any technology or device that would serve to circumvent such a technological measure..$^{50}$ Although Section 1201(a)(1)'s prohibition on the use of decryption technology to circumvent a technological lock is important, enforcing the use prohibition will require lawsuits against each individual user. For that reason, Section 1201(a)(1)'s use prohibition will prove largely inpractical to control widespread private copying. In contrast, Section 1201(a)(2) aims to bar access to decryption technology at the outset. By prohibiting the manufacture and importation of decryption technology, Section 1201(a)(2) seeks to eliminate the risk of widespread private copying without any need for lawsuits against the individual copiers. Instead, Section 1201(a)(2) authorizes copyright owners to control private copying through lawsuits against the relative handful of parties who would otherwise provide the decryption tools necessary to unlock encrypted works. If Section 1201(a)(2) is effective, decryption technology will never become available to or-

\footnotetext{
${ }^{49}$ Id. $\$ 1201$ (a)(1)(A).

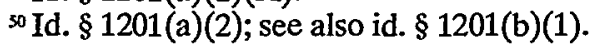


dinary consumers, and widespread private copying will never occur.

In order to contain decryption technology at its source, Section 1201(a)(2) significantly rewrites the rules pertaining to liability under Title 17 for individuals who market or distribute products that enable others to engage in unauthorized copying. Through three subsections offering slight variations on a theme, Section 1201(a)(2) bars the manufacture, importation, or distribution of any technology that can circumvent a copyright owner's technological lock. Section 1201(a)(2)(A) prohibits distribution of technology "primarily designed or produced for the purpose of circumventing" a technological lock." Section 1201(a)(2)(B) prohibits distribution of technology that "has only limited commercially significant purpose or use other than" circumventing a technological lock..$^{52}$ And Section 1201(a)(2)(C) prohibits distribution of technology that "is marketed ... for use in circumventing" a technological lock..$^{53}$

Before the DMCA, the vicarious hability standard that the Court established in Sony Corp. of America v. Universal City Stu$\operatorname{dios}^{54}$ governed the liability of an individual who made available technology that enabled others to engage in unauthorized copying of a copyrighted work. Under the Sony Corp. standard, an individual was liable for the copyright infringement her device made possible only if her device was incapable of any substantial noninfringing use. ${ }^{55}$ Although liability was not impossible to estabhish under the Sony Corp. standard, the standard proved a difficult hurdle for copyright owners. For example, when computer software publishers attenupted to control third-party distribution of decryption keys to their encrypted computer programs in the 1980 s, courts applying the Sony Corp. standard could usually find a

"Id. $\$ 1201(a)(2)(A)$.

"Id. $\$ 1201(\mathrm{a})(2)(\mathrm{B})$.

"Id. $\$ 1201(\mathrm{a})(2)(\mathrm{C})$.

464 U.S. 417 (1984).

"Id. at 442 (The sale of a product that enables copyright infringement "does not constitute contributory infringement if the product is widely used for legitimate, unobjectionable purposes" and that "it need merely be capable of substantial noninfringing uses."). 
substantial non-infringing use. ${ }^{56}$ So long as a decryption key could be used for copying that was either a fair use under Section $107,{ }^{57}$ a proper archival copy under Section $117,,^{58}$ or an otherwise noninfringing use, production and distribution of the key did not constitute copyright infringement.

Under Section 1201(a)(2), however, manufacturing or distributing a decryption key may violate the $\mathrm{DMCA}^{59}$ even if the key is capable of substantial non-infringing use. Such a result follows from two modifications that Sections $1201(\mathrm{a})(2)(\mathrm{A})$ and 1201(a)(2)(B) make to the Sony Corp. standard. First, these sections reduce the degree of involvement required to establisli hability. Second, they tie liability to the act of circumvention itself, rather than to some eventual act of copyright infringement.

In terms of the DMCA's first inodification to the Sony Corp. standard, we can think of technological devices as falling along a continuum ranging from those devices that lave only infringing uses to those devices that liave only legitimate uses. As we move from the "only legitimate use" end of this spectrum to the "only illegitimate use" end, it is fair to think of the party distributing the technology at issue as becoming progressively more involved in the infringement. Indeed, once we reach the "only illegitimate use" end of the spectrum, we can justifiably treat the person providing the device as if she herself is committing the resulting infringements given that there is no lawful use for her device. Most technological devices that enable the unauthorized copying of copyrighted works will fall somewhere in the middle, laving some

${ }^{56}$ See, e.g., Vault Corp. v. Quaid Software, 847 F.2d 255, 265-66 (5th Cir. 1988). But see Atari, Inc. v. JS \& A Group, 597 F. Supp. 5, 9-10 (N.D. Ill. 1983) (finding that distribution of a device that enabled copying of programs stored in ROM chips constituted contributory copyright infringement after concluding that $\S 117$ did not authorize archival copying of such programs).

s7 17 U.S.C. $\S 107$ (1994).

ss 17 U.S.C. \& 117 (Supp. V 2000).

${ }^{59}$ Rather than rely on copyright's general remedy provisions, the DMCA included its own remedies provisions that parallel those found in $\$ \S 501-06.17$ U.S.C. $\$ \S 1203-$ 04 (Supp. V 2000). The DMCA also refers to engaging in prohibited conduct as a "violation," rather than as an "infringement." Id. Although these differences at first appear merely curious, this seemingly trivial change in wording plays a significant role in interpreting the DMCA's anti-circunvention provisions. See infra text accompanying notes $89-94$. 
legitimate and some illegitimate uses, and the key legal question becomes where along the continuum hability will attach.

In Sony Corp., the Court defined the point where liability will attach in terms of whether the device at issue was capable of substantial nominfringing use. ${ }^{60}$ Under this standard, the fact that the technology was, in fact, used almost exclusively for infringement was not sufficient to establish liability. A plaintiff would have to further show that the teclmology was incapable of any substantial noninfringing use. In practice, the Sony Corp. standard limited liability to those devices very near the "only illegitimate use" end of our continuum. Only at this point did the Court feel justified in treating an individual distributing teclmology that made infringement possible as if she herself had committed the infringement. In his dissent in Sony Corp., Justice Harry Blackmun urged the Court to adopt a standard that focused more on the product's actual use, rather than its potential uses, insisting that "[o]nly the most unimaginative manufacturer would be unable" to satisfy a potential use or capability standard. ${ }^{61}$ Yet even Justice Blackmun acknowledged "that if a significant portion of the product's use is noninfringing, the manufacturers and sellers cannot be held contributorily liable for the product's infringing uses.",62

As compared to the Sony Corp. standard, the DMCA radically reduces the level of involvement required to establish liabihty for distributing teclmology that enables others to engage in unauthorized copying. ${ }^{63}$ Section 1201(a)(2)(B) defines liability in terms of whether the device "has only limited commercially significant purpose or use other than to circumvent" a technological control. ${ }^{64}$ Although the language is not perfecly clear, the "has ... purpose or

*'Sony Corp., 464 U.S. at 442.

"Id. at 498 (Blackmun, J., dissenting).

${ }^{n 2}$ Id. at 491 (Blackmun, J., dissenting).

nniversal City Studios v. Reimerdes, 111 F. Supp. 2d 294, 323-24 (S.D.N.Y. 2000) ("By prohibiting the provision of circumvention technology, the DMCA fundamentally altered the landscape. A given device or piece of technology might have a 'substantial nominfringing use, and hence be immune from attack under Sony's construction of the Copyright Act-but nonetheless still be subject to suppression under Section 1201.") (quoting RealNetworks, Inc. v. Streambox, Inc., No. C992070P, 2000 U.S. Dist. LEXIS 1889 at $* 23$ (W.D. Wash. Jan. 18, 2000)). But see H.R. Rep. No. 105-551, pt. 2, at 38 (1998) ("This provision $[\$ 1201(\mathrm{a})(2)]$ is not aimed at products that are capable of commercially significant noninfringing uses. ...").

17 U.S.C. $\$ 1201(\mathrm{a})(2)$ (B) (Supp. V 2000). 
use" phrase seems to focus more on actual, rather than potential, uses, apparently jettisoning Sony Corp.'s capability standard. ${ }^{65} \mathrm{Sec}$ tion 1201(a)(2)(A) goes even further. Under Section 1201(a)(2)(A), a person distributing technology violates the DMCA if the technology is "primarily designed or produced for the purpose of circumventing a technological measure that effectively controls access to a work protected under this title."66 Following the presumption that "people usually intend the natural consequences of their actions," ity under this section by assessing the predominant use of the technology at issue. ${ }^{68}$ If a device is used fifty-one percent of the time for circumvention and forty-mine percent for perfectly legitimate purposes, its primary use appears to be circumvention and distributing the device would likely therefore constitute a violation of Section 1201(a)(2)(A). As compared either to the majority or to the dissenting positions in Sony Corp., this represents a radical expansion of liability for the distribution of technology that enables others to engage in unauthorized copying.

Second, in addition to reducing the level of involvement required to establish hability, Section 1201(a)(2) modifies the nature of the culpable conduct. Under Sony Corp., liability turned on the technology's capacity for noninfringing use. ${ }^{69}$ If the copying that resulted was noninfringing, even if unauthorized, then the distributor of the technology could not be held liable. In contrast, the standards set forth in all three subsections of 1201(a)(2) tie liability to a technology's ability to circumvent "a technological measure that

${ }^{65} \mathrm{Id}$.

${ }^{66}$ Id. $\$ 1201(a)(2)(A)$.

${ }^{67}$ Reno v. Bossier Parish Sch. Bd., 520 U.S. 471, 487 (1997).

${ }^{6}$ Reimerdes, 111 F. Supp. 2d at 319. In discussing the defendants' liability under the DMCA for posting an encryption-breaking coinputer program to the Internet, the district court wrote:

Whether defendants [offered the program] in order to infringe, or to permit or encourage others to imfringe, copyrighted works in violation of other provisions of the Copyright Act simply does not matter for purposes of Section 1201(a)(2). The offering or provision of the program is the prohibited conduct-and it is prohibited irrespective of why the program was written, except to whatever extent motive may be germane to determining whether their conduct falls Id. within one of the statutory exceptions.

${ }^{69}$ See supra notes 55-58 and accompanying text. 
effectively controls access to a work protected under this title."70 This language imposes liability for distributing technology that circumvents a technological lock, even if the resulting access is fair or otherwise noninfringing. ${ }^{71}$ Because culpability under Section 1201(a)(2) turns on circumvention alone, sale or distribution of decryption keys constitutes a violation of Section 1201(a)(2), even if every single person who used the keys to circumvent a technological control did so to undertake a fair or otherwise non-infringing use of the protected work.

The expanded liability regime tliat Section 1201(a)(2) has wrought may be illustrated by comparing apphication of the Sony Corp. standard in one of the computer software encryption cases fron the 1980s to how the Section 1201(a)(2) standard would be apphied to the same case today. In Vault Corp. v. Quaid Software, ${ }^{72}$ the plaintiff had developed a technological ineasure designed to prevent unauthorized use or copying of computer programs. The plaintiff embedded this measure onto its PROLOK disks and sold the disks to computer software publishers. The publishers in turn would store their programs on the PROLOK disks and market them to tlie public. Within a few months, the defendant had developed and begun marketing a computer program that defeated the plaintiff's technological control. The plaintiff sued, alleging that the defendant was guilty of contributory or vicarious copyright infringement. ${ }^{73}$ Applying the Sony Corp. standard, the Fifth Circuit Court of Appeals rejected this argument, observing that the defendant's program allowed its users to inake proper archival copies under Section 117 of the Copyright Act. ${ }^{74}$ On that basis, without any consideration of how people were actually using the defendant's program, tlie Fifth Circuit held that the defendant's program was "capable of substantial noninfringing uses."75 The defendant

7) 17 U.S.C. \& 1201(a)(2)(A)-(C).

"Universal City Studios v. Reimerdes, 82 F. Supp. 2d 211, 219 (S.D.N.Y. 2000), permanent injunction issued, 111 F. Supp. 2d 294 (2000); RealNetworks, Inc. v. Streambox, Inc., No. C99-2070P, 2000 U.S. Dist. LEXIS 1889, at *22-23 (W.D. Wash. Jan. 18, 2000).

r. 847 F.2d 255 (5th Cir. 1988).

"Id. at 256-57.

" Id. at 266.

"Id. at 267. 
was therefore not liable for contributory or vicarious copyright infringement.

In contrast, if the DMCA were applied to those same facts, the defendant would almost certainly have violated Section 1201(a)(2). The defendant's program enabled its users to circumvent the plaintiff's copy protection program. The plaintiff's copy protection program controlled access to the computer programs stored on the PROLOK disks by limiting their unauthorized use or copying. And the computer programs stored on the PROLOK disks were works protected by copyright. Given these facts, manufacturing and distributing the defendant's program would constitute a violation under Section 1201(a)(2) without regard to whether the circumvention that resulted was otherwise infringing. ${ }^{76}$

Sections 1201(a)(2)(A) and 1201(a)(2)(B) thus radically expand the hability of an mdividual for distributing technology that circumvents a copyright owner's technological lock. Section 1201(a)(2)(C) achieves a similar result, although it appears to be directed at the parallel but slightly different issue of contributory infringement. Under the contributory infringement standard, "one who, with knowledge of the infringing activity, induces, causes or materially contributes to the infringing conduct of another, may be held liable." Although courts initially treated contributory infringement as subsumed within the Sony Corp. standard, at least in cases mvolving the distribution of copying technology, later decisions have treated contributory infringement as an alternate basis for hability. ${ }^{78}$ Nevertheless, ensuring consistency with the reasoning and results in Sony Corp. has placed limits on the potential reach of the contributory infringement doctrine. Given the Sony Corp. standard, the sale or distribution of a device that enables others to engage in copyright infringement should not, on its own, constitute a "material contribution" to that infringement as long as the device is capable of substantial noninfringing use. Similarly, because Sony

\footnotetext{
${ }^{76}$ See Reimerdes, 82 F. Supp. 2d at 219; RealNetworks, 2000 U.S. Dist. LEXIS 1889, at $* 22-23$.

$\pi$ Gershwin Publ'g Corp. v. Columbia Artists Mgmt., 443 F.2d 1159, 1162 (2d Cir. 1971) (footnote omitted).

${ }^{78}$ Compare Vault Corp., 847 F.2d at 262 (treating "vicarious" and "contributory" as intercliangeable terms for a single theory of third-party liability), with A\&M Records v. Napster, Inc., 239 F.3d 1004, 1027 (9th Cir. 2001) (treating vicarious and contributory liability as distinct theories of third-party liability).
} 
extensively advertised the ability of the Betamax to make unauthorized copies, Sony Corp. would also seem to preclude a finding of contributory infrimgement based upon advertising alone. ${ }^{79}$ Under Sony Corp., something more, some active inducelnent, is necessary before the contributory infringement doctrine would apply. ${ }^{\text {so }}$

Section 1201(a)(2)(C) rejects this need for something more. Section 1201(a)(2)(C) imposes liability for manufacturing or distributing a circumventing device if the device "is marketed ... for [a circumventing] use." ${ }^{81}$ Although the full breadth of the "is marketed for" standard is not clear, advertismg alone appears sufficient to establish liability, reversing the result im Sony Corp. itself. Advertising a device's capacity to make unauthorized copies, as Sony did, would presumably constitute marketing and would establish the manufacturer's hability under Section 1201(a)(2)(C). More generally, Section 1201(a)(2)(C) may extend liability to cases where the circumvention capacity of a technology is advertised, even if the technology is in fact used predominantly for legitimate, non-circumvention purposes. ${ }^{\$ 2}$ Perhaps courts will interpret the "is marketed for" standard to require something more than a mere mcidental acknowledgement of a technology's capacity to circumvent encryption protecting copyrighted works. Nevertheless, compared to copyright's traditional contributory imfringement doctrine, the hiteral language of Section 1201(a)(2)(C) substantially expands the circumstances under which an individual

${ }^{79}$ Sony Corp. involved a suit against Sony regarding its potentially copyrightinfringing Betamax VCR. Sony Corp., 464 U.S. at 459. There was undisputed evidence in the case that Sony extensively advertised the Betamax's ability to copy television programs. ld. at 459,489 (Blackmun, J., dissenting).

* For example, in Sega Enterprises v. Maphia, 948 F. Supp. 923, 929 (N.D. Cal. 1996), the defendants offered for sale a device for decoding programs stored im game cartridges for particular video game systems. As part of the sales pitch for the device, the defendants offered buyers free access to their bulletin board, so that any given buyer could upload the files she had decoded from her own video game cartridges and download the files other buyers had decoded from their video game cartridges. Id. at 927. Finding that this promotional offer actively induced copyright infringement by the purchasers of their device, a district court found the defendants liable for contributory copyright infringement. Id. at 933.

"17 U.S.C. \& 1201(a)(2)(C) (Supp. V 2000).

* S. Rep. No. 105-190, at $11 \mathrm{n} .19$ (1998) ("Note that even if a device does not have circumvention as its primary purpose or design, that is, that it does not fall within the prohibition of Section $1201(\mathrm{a})(2)(\mathrm{A})$, the device would still be illegal if it fell within the prohibitions of either 1201(a)(2)(B) and [sic] (C)."). 
can be held liable for distributing technology capable of making unauthorized copies of a protected work.

On its face, therefore, the DMCA substantially expands liability for the manufacture, importation, and distribution of technology that could unlock the technological protection that copyright owners attach to their works. Concerned that unconstrained encryption might allow copyright owners to go too far in protecting their works (or perhaps merely to placate opposition to the DMCA), Congress included three provisions in the DMCA to limit the risk that encryption would serve primarily the private interest of copyright owners, rather than the public interest more generally. First, Section 1201(a)(1)(B) exempts certain classes of copyrighted works from Section 1201(a)(1)(A)'s anti-circumvention provision. ${ }^{83}$ For these classes of works, circumvention of a technological lock does not violate the DMCA. Section 1201(a)(1)(B) defines the exempt classes generally as those classes of works whose users "are, or are likely to be" adversely affected "m their ability to inake noninfringing uses" as a result of encryption. ${ }^{84}$ Applying this general standard, the DMCA authorizes the Librarian of Congress to determine the precise classes of works exeinpt from Section 1201(a)(1)(A)'s anti-circumvention provision through a tri-annual rulemaking proceeding. ${ }^{85}$ Although some legislators and scholars had hoped that the Librarian would use Section 1201(a)(1)(B) to issue a broad exemption for research, criticism, and teaching, parallehing the fair use doctrine, ${ }^{86}$ the Librarian's initial rulemaking

$\$ 17$ U.S.C. $\S 1201$ (a)(1)(B); see also H. R. Rep. No. 105-551, pt. 2, at 26 (1998) ("The Committee has struck a balance that is now embodied in Section [1201(a)(1)] of the bill.... The Committee has endeavored to specify, with as much clarity as possible, how the right against anti-circumvention would be qualified to maintain balance between the interests of content creators and information users. The Committee considers it particularly important to ensure that the concept of fair use remains firmly established in the law.").

\& 17 U.S.C. $\& 1201(\mathrm{a})(1)(B)$.

${ }^{85}$ Id. \& 1201(a)(1)(C).

${ }^{85}$ See 144 Cong. Rec. H7093 (daily ed. Aug. 4, 1998) (statement of Rep. Bliley) (describing $\$ 1201(\mathrm{a})(1)(\mathrm{B})$ as a "strong fair use provision [intended] to ensure tliat consumers as well as libraries and institutions of higher learning will be able to continue to exercise their historical fair use rights"); see also Copyright Office, Final Rulemaking, 65 Fed. Reg. 64,555, 64,572-73 (Oct. 27, 2000) (to be codified at 37 C.F.R. 201.40(b)) (noting and rejecting Professor Peter Jaszi's proposed exemption under $\S 1201(\mathrm{a})(1)(B)$ for a class of works consisting of "works embodied in copies 
exempted only two classes of works from Section 1201(a)(1)(A)'s protection: "1. Compilations consisting of lists of websites blocked by filtering software applications; and 2 . Literary works ... protected by access control mechanisms that fail to permit access because of malfunction, damage or obsoleteness."

As a second limit on the DMCA's potential for advancing the private interests of copyright holders at the expense of the public interest, Congress specifically stated in Section 1201(c) that the DMCA does not limit the fair use defense or expand the scope of contributory or vicarious hability. Section 1201 (c)(1) states that "[n]othing in this section shall affect ... limitations, or defenses to copyright infringement, including fair use." $\$ 9$ Section 1201(c)(2) states that "[n]othing in this section shall enlarge or dimimsh vicarious or contributory liability for copyriglit infringement." 90 Although these provisions appear to incorporate these important public interest safeguards directly into the DMCA, closer inspection reveals that the apparently firm guaranties im Section 1201(c) prove deceptively enipty. Both subsections state that the DMCA shall not affect these doctrines for purposes of "copyright infringement." But there is a catch. The DMCA has its own civil and criminal remedies provisions. ${ }^{91}$ Liability arises under these sections not for "copyright infringement," but for violations of Sections 1201 or 1202 . $^{92}$ The DMCA thus creates a distinction between

which have been lawfully acquired by users who subsequently seek to make noninfringing uses thereof").

${ }^{x 7}$ Copyright Office, Final Rulemaking, 65 Fed. Reg. at 64,574. Moreover, even if the Librarian in some future rulemaking should expand the classes of exempt works, the exemption in $\$ 1201(\mathrm{a})(1)(\mathrm{B})$ applies only to $\$ 1201$ (a)(1)(A)'s prohibition on the circumvention of a technological lock. 17 U.S.C. $\$ 1201$ (a)(1)(B). The $\$ 1201(\mathrm{a})(1)(B)$ exemption does not apply to $\$ 1201(a)(2)$. Id. As a result, while use of decryption technology to obtain access to the exempt class of works would not violate the DMCA, manufacturing or distributing the decryption technology necessary to obtain such access would still apparently violate $\$ 1201$ (a)(2). Cf. Universal City Studios v. Reimerdes, 111 F. Supp. 2d 294, 324 (S.D.N.Y. 2000) ("The fact that Congress elected to leave technologically unsophisticated persons who wish to make fair use of encrypted copyrighted works without the technical means of doing so is a matter for Congress....").

* 17 U.S.C. $\$ 1201$ (c).

"Id. \$ 1201(c)(1).

"Id. \$1201(c)(2).

${ }^{4}$ Id. \$\$ 1203-04.

" Id. $\$ \$ 1203(\mathrm{a}), 1204(\mathrm{a})$. 
copyright infringement and violations of the $\mathrm{DMCA} .^{93}$ As a result, the public interest guaranties offered in Sections 1201(c)(1) and 1201(c)(2) are meaningless. These sections may help ensure that the fair use and contributory or vicarious liability doctrines continue to apply in determining whether "copyright infringement" has occurred, but they do not incorporate these doctrines into the determination of whether a "violation" of the DMCA has occurred. $^{94}$

Third, a few other sections offer limited exemptions to the DMCA's restrictions on the use of and access to decryption technology. But these exemptions are unlikely to provide any real constraint on the ability of copyright owners to use encryption technology to advance their own welfare at the expense of the public's. For example, Section 1201(d)(1) grants nonprofit libraries the ability to use decryption to gain unauthorized access to an encrypted work." The library, however, may gain access "solely in order to make a good faith determination whether to acquire a copy of that work," and any resulting copy "may not be retained longer that necessary to inake such good faith determination." There are similarly limited exemptions in Section 1201(f), authorizing the use of decryption to obtain access to a coinputer program solely to identify and analyze those elements necessary to achieve

93 The legislative history supports this distinction:

H.R. 2281, as reported by the Committee on the Judiciary, would regulate-in the name of copyright law-the manufacture and sale of devices that can be used to improperly circumvent technological protection measures. The Committee on Commerce adopted an amendment that moves the anticircumvention provisions out of Title 17 and establishes them as free-standing provisions of law... The anti-circumvention provisions (and the accompanying penalty provisions for violations of them) would be separate from, and cuinulative to, the existing claims available to copyright owners.

H.R. Rep. No. 105-551, pt. 2, at 23-24 (1998).

${ }^{4}$ See Universal City Studios v. Reimerdes, 82 F. Supp. 2d 211, 219 (S.D.N.Y. 2000) ("Defendants, however, are not here sued for copyright infringement. They are sued for offering to the public and providing technology primarily designed to circumvent technological measures that control access to copyrighted works and otherwise violating Section 1201(a)(2) of the Act. If Congress had ineant the fair use defense to apply to such actions, it would have said so.").

ss 17 U.S.C. \& 1201(d)(1).

${ }^{96}$ Id. 
interoperability, ${ }^{97}$ and in Section 1201(g), authorizing encryption research. ${ }^{9 *}$

Having freed copyright owners froin the specter of third-party decryption keys, the DMCA places no real limits on the ability of copyright owners to use encryption to maximize their own revenue. Instead, the DMCA replicates the system of legally backed technological controls that enabled the Stationers' Company to monopolize the publication of printed works in England more than three hundred years ago. Given the difficulties encountered in the last Anglo-American experience with a guild inonopoly, Congress's decision to return to a guild monopoly as the model for protection in the "Digital Millennium" is surprising, indeed startling. Such an approach places at risk essentially all of the public interest protections found both in the Statute of Anne and in copyright law more generally.

Consider, for example, the three changes that from the outset distinguished the Statute of Anne from the guild monopoly of the Stationers' Company: (1) adoption of the originality requirement; (2) imposition of a limited duration for protection; and (3) delegation of the task of defining protection's proper scope to an independent judiciary. On all three of these issues, the DMCA embraces the approach followed under the guild monopoly of the Stationers' Company. By generally prohibiting the distribution of decryption technology, the DMCA extends protection to unoriginal works potentially indefinitely. The DMCA also returns responsibility for determining protection's proper scope to the copyright industry itself.

On the issues of originality and the duration of protection, the DMCA generally prohibits the distribution of decryption technology and thereby enables individuals to rely on encryption to effectively bar unauthorized access and copying. Encryption tecl1nology does not, however, distinguish between works that copyright protects and those left unprotected. It can bar unautliorized access to any file, whether or not the work contained within is protected by copyright. ${ }^{99}$ If decryption technology is generally un-

${ }^{47}$ Id. $\$ 1201(\mathrm{f})$.

Id. $\$ 1201(\mathrm{~g})$.

* See Kenneth W. Dam, Self-Help in the Digital Jungle, 28 J. Legal Stud. 393, 394, 396-97 (1999) (recognizing that result by arguing that use of encryption to protect 
available, individuals can use encryption to protect digital files that copyright leaves unprotected.

Congress attempted to avoid this result by limiting application of the anti-circumvention prohibitions in Sections 1201(a)(1) and 1201(a)(2) to cases where the technological measure controls access to a work "protected under this title.",100 The dual use nature of decryption technology, however, will likely defeat Congress's attempt to limit the use of encryption to copyrighted works. Almost invariably, the same decryption technology that enables individuals to decrypt works not protected by copyright will also enable individuals to decrypt works protected by copyright. For example, in one of the first cases brought under the DMCA, Universal City Studios v. Reimerdes, ${ }^{101}$ eight motion picture studios sued to enjoin the distribution of a computer program known as DeCSS. ${ }^{102}$ This program defeated the encryption system the motion pictures studios were using to protect their copyrighted works. Finding a violation of the DMCA, the district court enjoined distribution of DeCSS. ${ }^{103}$ This result not only enables the motion picture studios to use their Contents Scramble System (or CSS) to protect works covered by copyright, but it also allows them to use CSS to protect works that fall outside of copyright. If a motion picture studio used CSS to encrypt both recent fihns still within copyright's term and older films no longer protected by copyright, then under the precise language of the DMCA, the use of DeCSS to decrypt the older films unprotected by copyright would not violate Section 1201(a)(1). The manufacture and distribution of DeCSS, however, would likely remain a violation of Section 1201(a)(2) because DeCSS could be used to decrypt the more recent films as well. Given decryption technology's potential for both legitimate and illegitimate use, the question would become whether the technology was primarily designed to decrypt copyrighted works or to decrypt uncopyrighted works. Because the decryption technology is necessarily designed for both tasks, a court would likely resolve this

uncopyrightable and public domain materials "should not be viewed as conflicting with the imtellectual property law of copyright").

${ }_{100} 17$ U.S.C. $\S 1201(\mathrm{a})(1)(\mathrm{A}),(\mathrm{a})(2)(\mathrm{A})-(\mathrm{C})$.

tol 111 F. Supp. 2 d 294 (S.D.N.Y. 2000).

102 Id. at 303.

${ }^{103}$ Id. at $317-19,345$. 
issue by looking at the technology's actual use. ${ }^{104}$ To the extent that the decryption technology could break the lock on more, or more valuable, works still within copyright, a court could reasonably find the technology "primarily designed" to decrypt works "protected under this title." Distribution of the technology would therefore violate Section 1201(a)(2), even if the technology were also necessary to break encryption locks on digital works unprotected by copyright.

As a result, despite Congress's attempt to limit the anticircumvention provisions to works "protected under this title," the practical consequences of the DMCA's general ban on decryption technology are broader than the formal language. Under the precise language of the DMCA, an individual remains formally free to decrypt a non-copyrighted work and copy it. Yet, because of its inevitable dual use nature, distribution of the necessary decryption technology would likely be a violation of Section 1201(a)(2). As a practical matter, then, it is unclear how or where ordinary consumers would obtain the decryption technology necessary to break the encryption lock on digital information unprotected by copyright. For that reason, although the DMCA does not formally repudiate the originality or limited times limitations on protection first found in the Statute of Anne, the DMCA's general prohibition on the distribution of decryption technology achieves that result nonetheless. ${ }^{\text {jos }}$

The DMCA also largely eliminates the judiciary as the central arbiter of copyright protection's proper scope. Through its reliance on encryption-based protection, the DMCA empowers copyright owners themselves to balance the public and private interests at stake. With encryption, copyright owners will be in a position to try and protect their works as they see fit. This is not to say that copyright owners will necessarily exercise tlreir newfound authority to eliminate all limitations on protection, or that they could even do so if they tried. Encryption technology has its limits, and even where protection is technically feasible, soine limitations on the scope of protection may coincide with the interests of copyright

\footnotetext{
${ }^{104}$ See id. at 319.

ur See David Nimmer, A Riff on Fair Use in the Digital Millennium Copyright Act, 148 U. Pa. L. Rev. 673, 729 (2000).
} 
owners. ${ }^{106}$ Nevertheless, any number of copyright doctrines are unlikely to survive in an encryption-based world, such as the first sale doctrine in Section $109,{ }^{107}$ the authorization for archival copies in Section $108^{103}$ and Section 117(a), ${ }^{109}$ the authorization for repair copies in Section 117(c) ${ }^{110}$ and the authorization for nonprofit research and teaching copies under Section $107 .{ }^{111}$ Yet, the major concern here is not with whether particular limitations will survive, but with the more general bias copyright owners will bring to defining the proper scope of protection. While courts may not always have seen the pubhic interest clearly in copyright cases, they at least did not have their own money at stake. Copyright owners will. That self-interest will undoubtedly cloud copyright owners' perception of the balance between public and private interest and will tilt protection in favor of copyright owners.

By replacing the judiciary with copyright owners as the central arbiter of protection's proper scope, the DMCA replaces the public interest in the creation and dissemination of works of authorship with the private interest of maximizing the revenue of copyright owners. Given this fact, the only plausible argument that might justify the DMCA in the light of the Constitution's public interest inandate is that Congress had no choice. Facing the risk of widespread private copying that digital technology creates, proponents of the DMCA will undoubtedly argue that the DMCA's rehance on technology-based control represents the only viable means to ensure an adequate supply of creative works. Otherwise, those proponents might argue, the risk of widespread private copying will undermine completely the incentive to produce such works. To determine whether Congress had no choice, Part II turns to a consideration of the available alternatives. Examining these alternatives may reveal whether another approach might better redress whatever threat private copying poses for creative work while still preserving copyright's public interest focus.

${ }^{106}$ William M. Landes \& Richard A. Posner, An Economic Analysis of Copyright Law, 18 J. Legal Stud. 325, 332-33 (1989).

${ }_{107} 17$ U.S.C. $\$ 109$ (1994 \& Supp. V 2000).

${ }^{108}$ Id. $\$ 108$.

${ }^{108} 17$ U.S.C. $\$ 117($ a) (Supp. V 2000).

${ }^{110}$ Id. $\$ 117(\mathrm{c})$.

"11 17 U.S.C. $\$ 107$ (1994). 


\section{ADDRESSING THE RISK OF WIDESPREAD PRIVATE COPYING WITHOUT BETRAYING THE PUBLIC INTEREST}

Other than the DMCA, there are three general approaches that copyright law might take in the face of private copying. First, it could retain an encryption-based approach, but modify or imterpret the DMCA to include limitations on encryption-based protection to ensure that it serves primarily the public interest. Second, it could abandon an encryption-based approach altogether and substitute some alternative approach in its stead. Third, it could abandon encryption and trust American consumers to regulate themselves. The following Sections discuss each of these three general approaches in turn.

\section{A. A Modified Encryption-Based Approach}

If the problem with encryption-based protection is that it permits copyright owners (and others) to over-protect their works, the obvious solution is to inpose limits on the permissible bounds of encryption. For contractual restrictions on use and copying ("CRUCs"), a number of commentators have discussed the use of preemption to bar excessive restrictions ${ }^{112}$ - an approach that has received a decidedly mixed judicial reception. ${ }^{113}$ CRUCs, however, are a matter of state law and therefore subject to preemption where they "stand[] as an obstacle to the accomphishment and exe-

${ }^{112}$ E.g., David A. Rice, Public Goods, Private Contract and Public Policy: Federal Preemption of Software License Prohibitions Against Reverse Engineering, 53 U. Pitt. L. Rev. 543 (1992); see generally Julie E. Cohen, Lochner in Cyberspace: The New Economic Orthodoxy of "Rights Management" 97 Micl. L. Rev. 462, 485-86 (1998) (discussing the conditions in which copyright law might preempt contract terms); Mark A. Lemley, Intellectual Property and Shrinkwrap Licenses, 68 S. Cal. L. Rev. 1239. 1271 (1995) (noting that "[f]ederal intellectual property law ... does not 'preempt the field' entirely"); Michael J. Madison, Legal-Ware: Contract and Copyright in the Digital Age, 67 Fordham L. Rev. 1025, 1127-32 (1998) (noting limited scope of preemption of contract law by copyright law); J.H. Reichman \& Jonathan A. Franklin, Privately Legislated Intellectual Property Riglits: Reconciling Freedom of Contract with Public Good Uses of Information, 147 U. Pa. L. Rev. 875, 920-22 (1999) (discussing shortfalls of preemption doctrine as a tool for understandmg copyright issues).

${ }^{\prime \prime}$ Compare Vault Corp. v. Quaid Software, 847 F.2d 255, 269-70 (5th Cir. 1988) (applying preemption to prohibit enforcement of CRUCs under state law), with ProCD, Inc. v. Zeidenberg, 86 F.3d 1447, 1453-55 (7th Cir. 1996) (refusing to preempt CRUCs that prohibit commercial use of factual data). 
cution of the full purposes and objectives of Congress." 114 In contrast, Congress has expressly authorized encryption-based protection in the DMCA. As the DMCA is itself federal law, preemption, whether of the express statutory variety or the inplied constitutional variety, is not an option for controlling overbroad encryption-based protection. ${ }^{115}$ Courts could, however, attempt to limit overbroad encryption-based protection by incorporating the fair use doctrine and other limitations on copyright protection into the DMCA's anti-circumvention provisions. ${ }^{116}$ This would soften the terns of the DMCA and allow a defendant to avoid liability by showing that, even though she circumvented a technological control, the resulting use or access was fair or otherwise noninfringing.

Incorporating the fair use doctrine and other limitations on copyright protection seems to contradict the plani language distinction that the DMCA draws between "violations" of the DMCA and "copyright infringement."117 Nevertheless, a court has several plausible bases for incorporating the fair use doctrine (and perhaps other limitations on copyright protection) directly into the DMCA's anti-circumvention provisions. First, interpreting Section 1201(c) as a type of savings clause that merely preserves fair use in cases involving traditional copyright infringenent claims would render Section 1201(c) alinost entirely superfluous. Nothing in the DMCA suggests that the DMCA intended to overturn the fair use doctrine for copyright infringement generally; as a result, a savings clause appears unnecessary. A narrow interpretation of Section 1201(c), restricting its apphication to copyright infringement, would therefore violate a cardinal tenet of statutory interpretation: Courts must give effect, if possible, to every word in a statute. For Section 1201(c) to have any substantive meaning at all, courts presumably should interpret the section as something other than a simple restatement of the obvious. ${ }^{118}$ Yet, the relevant legislative history seems to relegate Section 1201 (c) to such a trivial role. ${ }^{19}$

\footnotetext{
${ }^{114}$ Hines v. Davidowitz, 312 U.S. 52, 67 (1941).

${ }^{115}$ Denicola, supra note 1 , at 197-99.

${ }^{116}$ In theory, we could also implement this approach by enacting a federal law that affirmatively prohibits, and provides appropriate sanctions for, the use of encryption likely to bar fair or otherwise noninfringing uses.

${ }^{117}$ See supra text accompanying notes 88-94.

${ }^{118}$ Another argument for incorporating the fair use doctrine and other linitations on copyright protection into the DMCA's anti-circumvention provisions relies on
} 
As an alternative approach to incorporating the fair use doctrine into the DMCA, a court might rely on the belief that courts originally crafted the fair use doctrine without express statutory authorization as justification for applying the doctrine to the DMCA. Although this behef does not rest on an entirely firm foundation, ${ }^{\mathrm{I} 0}$ the serious constitutional questions that would otherwise arise from a plain language interpretation of the DMCA might justify such incorporation. Given that fair use and copyright's other limitations are intended to ensure that copyright serves "the Progress of Science," removing them may prove beyond Congress's constitutional authority under the Patent and Copyright Clause. ${ }^{121}$ Although the Eleventh Circuit has allowed Congress to avoid a limitation inherent in the Patent and Copyright Clause by resorting to its Commerce Clause authority, ${ }^{122}$

$\$ 1201(b)(1) .17$ U.S.C. $\$ 1201(b)(1)$ (Supp. V 2000). Section 1201(b)(1) closely parallels \$1201(a)(2), prohibiting the manufacture and distribution of technology that "is primarily designed" for, "has only limited commercially significant purpose or use other than." or "is marketed" for circumvention. Id. \$1201(b)(1)(A)-(C). Section 1201(b)(1). however, prohibits such actions as to "a technological measure that effectively protects a right of a copyright owner under this title," id. (emphasis added), rather than prohibiting such actions as to "a technological measure that effectively controls access to a work protected under this title," id. $\$ 1201(\mathrm{a})(2)(\mathrm{A})-(\mathrm{C})$. Because a copyright owner's exclusive rights under $\$ 106$ are expressly "[s]ubject to sections 107 through 121," 17 U.S.C. \$ 106 (1994 \& Supp. V 2000), the phrase "right of a copyright owner under this title" found in $\$ 1201($ b)(1) inay implicitly incorporate the limitations on copyright protection set forth in $\$ \$ 107$ through 121 , including the fair use doctrine.

"See WIPO Copyright Treaties Inplementation Act; and Online Copyright Liability Limitation Act: Hearing on H.R. 2281 and H.R. 2280 Before the Subcomm. on Courts and Intellectual Prop. of the House Comm. on the Judiciary, 105th Cong. 49-50 (1997) (prepared statement of Marybeth Peters, register of copyrights, Copyright Office of the United States, Library of Congress) (recognizing the potential threat strong encryption-based protection presents to fair use but recognizing that "[a]s drafted, however, the [savings] clause does not establish fair use as a defense to the violation of section 1201 im itself"); see also S. Rep. No. 105-190, at 30 (1998) ("Together these provisions are intended to ensure that none of the provisions in section 1201 affect the existing legal regime established in the Copyright Act and case law interpreting that statute.").

${ }^{121}$ See Glynn S. Lunney, Jr., Reexamining Copyright's Incentives-Access Paradigm, 49 Vand. L. Rev. 483, 502 n.70 (1996) (noting that historically the himitation of fair use was seen as implicit in the meaning of the word "copy").

"21 U.S. Const. art. I., $\$ 8$, cl. 8.

322 United States v. Moghadam, 175 F.3d 1269, 1280 (11th Cir. 1999), cert. denied 529 U.S. 1036 (2000) (concluding "that the Copyright Clause does not envision that Congress is positively forbidden from extending copyright-like protection under other constitutional clauses, sucl as the Commerce Clause, to works of authorship that may 
courts have also emphasized fair use's central role in ensuring that the protection Congress extends to copyrighted works does not violate the First Amendment's guaranty of free speech. ${ }^{123}$ If courts follow through on this reasoning, the DMCA may prove constitutionally infirm if interpreted to exclude the fair use doctrine whether the DMCA is treated as an exercise of Congressional power under the Patent and Copyright Clause or under the Commerce Clause. ${ }^{124}$ To avoid finding the DMCA unconstitutional, or

not meet the fixation requirement inherent in the term 'Writings"'); see also Authors League of Am. v. Oman, 790 F.2d 220, 224 (2d Cir. 1986) (upholding the now-expired manufacturing clause of the Copyright Act); U.S. Copyright Office, Report on Legal Protection for Databases 108-110 (1997) (reaching the conclusion that Congress likely had authority to protect unoriginal databases under the Commerce Clause). But see Rochelle Cooper Dreyfuss, A Wiseguy's Approach to Information Products: Muscling Copyright and Patent into a Unitary Theory of Intellectual Property, 1992 Sup. Ct. Rev. 195, 230 ("Restrictions on constitutional grants of legislative power, such as the Copyright Clause, would be meaningless if Congress could evade them simply by announcing that it was acting under some broader authority."); John J. Flynn, The Orphan Drug Act: An Unconstitutional Exercise of the Patent Power, 1992 Utah L. Rev. 389, 414 n.81 ("[T]he Commerce Clause and the Patent Clause should be read together as estabishing an implicit policy of precluding the federal government from granting private parties unregulated and exclusive monopolies over economic activity other than that authorized by the Patent Clause."). Moghadam does not directly apply to the DMCA, given that the works protected under the DMCA are also works protected under copyright. See Brief Amicus Curiae of Intellectual Property Law Professors at 21-23, Universal City Studios v. Corley (2d Cir. submitted Jan. 26, 2001) (No. 00-9185), http:/www.law.georgetown.edu/faculty/jec/2600ipprofsamicus.pdf.

${ }_{123}$ E.g., Harper \& Row Publishers v. Nation Enters., 471 U.S. 539, 559-60 (1985). Of course, scliolars have long recognized these recitations as mere form rather than substance. Lyman Ray Patterson, Copyright in Historical Perspective 225 (1968) ("The contradiction of protecting ideas as private property in a society devoted to freedom of expression has been rationalized away with assurances that copyright does not protect ideas, but only the expression of ideas. The rationalization, however, will not stand up in light of the concept of copyright as it exists today.").

${ }^{124}$ See Benkler, supra note 18, at 548-52 (arguing that both the Patent and Copyright Clause and the First Amendment place constitutional limits on congressional authority to create property rights im information); Yochai Benkler, Free as the Air to Common Use: First Amendment Constraints on Enclosure of the Public Domain, 74 N.Y.U. L. Rev. 354, 414-29 (1999) (arguing that the DMCA, by authorizing private enclosure through encryption, may violate the First Amendment); Julie E. Cohen, Copyright and the Jurisprudence of Self-Help, 13 Berkeley Tech. L.J. 1089, 1131-34 (1998) (same); William Patry, The Enumerated Powers Doctrine and Intellectual Property: An Imminent Constitutional Collision, 67 Geo. Wash. L. Rev. 359, 361 (1999) ("When a specific clause of the Constitution, such as Clause 8 of Article I, Section 8, has been construed as containing general limitations on Congress's power, Congress may not avoid those himitations by legislating under another clause."); Patterson, supra note 12, at 374 ("For Congress to use the copyright clause to delegate to copyright holders powers that the First Anendment denies to 
to avoid confronting the serious questions as to constitutionality that would otherwise arise, a court could plausibly adopt a broader reading of Section 1201(c) that would incorporate fair use directly as a limitation on the DMCA's anti-circumvention provisions.

Nevertheless, even if a court could be persuaded to incorporate fair use and other limitations on copyright protection into the DMCA, such a step would not necessarily solve the problem that digital technology presents, nor restore the balance copyright has sought to establish over the last two hundred years. Digital technology has fundamentally altered copyright doctrine by making widespread private copying possible. Although the fair use doctrine has played a central role historically in defining copyright's limits, it presupposes: (1) that the copyright owner will be able to identify the alleged infringement in order to bring it before the court; and (2) that a judicial proceeding represents a viable means for resolving the dispute. Private copying challenges both of these necessary preconditions. Because it is private, this sort of copying is more difficult to identify and bring before the court. And even if identified in some cases, the costs of resolving the question of infringement through a judicial proceeding are prohibitive. As a result, unless otherwise effectively controlled, private copying would continue, not because a court liad balanced the public and private interests at stake and found the private copying to be fair, but because anonymity and the safety of numbers would insulate the private copier's actions from judicial scrutiny.

Given that digital technology has fundamentally altered the balance copyright seeks to achieve, leaving the fair use and Sony Corp. doctrines in place would have rendered any attempt to control private copying impotent. If Congress had prohibited circumvention of a technological control only where it led to infringement, such a prohibition would prove superfluous. It would require the copyright owner to prove both circumvention and infringement, whereas traditional copyright requires a showing of infringement alone.

Similarly, if Congress had retained the Sony Corp. standard, decryption technology and the resulting ability to engage in private copying would likely have becoine commonplace. Although de-

Congress to control access to published works that have been purchased in the open market-makes little sense and worse policy."). 
cryption technology once commonly came as a physical devicethe infamous "black box"125-decryption technology increasingly comes in the form of computer programs. Consider, for example, the decryption technology at issue in the cases brought to date under the DMCA. Several involve physical devices analogous to the black box. ${ }^{126}$ Others, however, involve computer programs that defeat a copyright owner's technological controls. ${ }^{127}$

Where the decryption technology at issue is a computer program, the difficulties of circumscribing its availability once the program has been pubhished are obvious. In Universal City Studios $v$. Reimerdes, ${ }^{128}$ for exainple, once the DeCSS program was posted, it becaine imstantly available to anyone with access to the Inter-

${ }^{125}$ During the floor debate over the DMCA, at least some senators expressed the view that the anti-circumvention provisions reached only such black boxes. For example, then-Senator John Ashcroft stated:

In discussing the anti-circumvention portion of the legislation, I think it is worth emphasizing that I could agree to support the bill's approach of outlawing certain devices because $I$ was repeatedly assured that the device prohibitions in 1201(a)(2) and 1201(b) are aimed at so-called "black boxes" and not at legitimate consunier electronics and computer products that have substantial non-infringing uses. I specifically worked for and achieved changes to the bill to make sure that no court would misinterpret this bill as outlawing legitimate consumer electronics devices or computer hardware. As a result, neither section 1201(a)(2) nor section 1201(b) should be read as outlawing any device with substantial non-infringing uses....

144 Cong. Rec. $\$ 4890$ (daily ed. May 14, 1998) (statement of Sen. Ashcroft); see also 144 Cong. Rec. $\mathrm{H} 7094$ (daily ed. Aug. 4, 1998) (statement of Rep. Bliley) (stating that "In our report, the Committee stressed that section 1201(a)(2) is aimed fundamentally at outlaying [sic] so-called 'black boxes' that are expressly intended to facilitate circumvention of protection measures for purposes of gaining access to a work. This provision is not aimed at products that are capable of commercially significant noninfringing uses ....").

${ }^{126}$ CSC Holdings v. Greenleaf Elecs., No. 99-C7249, 2000 U.S. Dist. LEXIS 7675, at *24 (N.D. Ill. June 1, 2000) (finding a likely violation of DMCA as a result of sales of a cable descrainbler and decoder); RealNetworks, Inc. v. Streambox, Inc., No. C992070P, 2000 U.S. Dist. LEXIS 1889, at $* 2-3$ (W.D. Wash. Jan. 18, 2000) (finding a likely violation of DMCA as a result of sales of a "Streambox VCR" that decoded the plaintiff's encrypted works); Sony Computer Entm't Ain. v. Gameniasters, 87 F. Supp. 2d 976, 987 (N.D. Cal. 1999) (finding that the sale of a piece of game equipment, the "Game Enhancer," that altered certain codes in the plaintiff's encrypted games likely violated the DMCA).

127 Universal City Studios v. Reimerdes, 111 F. Supp. 2d 294, 317-19 (S.D.N.Y. 2000) (finding that defendant's posting of the DeCSS computer prograin on his website violated the DMCA); RealNetworks, 2000 U.S. Dist. LEXIS 1889, at *33 (finding that defendant's distribution of its Ferret coniputer program likely violated the DMCA).

${ }^{128} 111$ F. Supp. 2d 294 (S.D.N.Y. 2000). 
net. ${ }^{129}$ Although knowledge of it undoubtedly took longer than an instant to filter out, its portability and ease of duplication once available as a digital posting on the Internet are readily apparent. ${ }^{130}$ Because it was capable of noninfringing uses, the DeCSS program would have avoided liability under the Sony Corp. standard. Yet, the program was equally capable of infringing uses. If its distribution were lawful, the program would undoubtedly reopen the door to widespread private copying of copyrighted works.

For these reasons, neither incorporating the fair use defense nor restoring the Sony Corp. standard would reestablish copyright's traditional balance in today's digital age. A inodified DMCA would simply tilt the balance in favor of private copiers by allowing them to remain beyond the law's reach. As a result, if private copying poses the threat to the creation of works of authorship that the copyright industry fears, then a modified DMCA is unlikely to address that threat adequately.

\section{B. Alternatives to Encryption}

Another alternative to the DMCA would be to extend the stopgap measures that copyright has already employed. For example, Congress could increase even further the penalties associated with copyright infringement. With increased penalties, even a few private copying prosecutions could serve as examples that would deter private copying more generally. This approach is problematic, however. Given the transaction costs involved, legal action against individual private copiers would likely be brought against only a relative handful of those involved in the activity. For those few prosecutions to deter private copying generally, courts would need to punish the few infringers chosen for prosecution to an extent radically disproportionate to the wrong they committed. At some point, a point copyright law inay have already reached, the

${ }^{124}$ Id. at 303.

${ }^{1 *}$ The lawsuit was filed in January 2000 , and the district court granted a preliminary injunction against the defendants' posting in the same month. Id. at 312 \& n.92. While this is fast work for a district court, the preliminary injunction still came far too late to prevent widespread distribution of the DeCSS program. See id. at 312 (noting that the defendants "continued to support links to other web sites purporting to offer DeCSS for download, a hst which had grown to nearly five hundred by July 2000 "). 
level of punishment required to deter private copying generally will simply become unjust. Alternatively, Congress might attempt to retain copyright's traditional approach of legal action against each individual infringer, but improve its effectiveness by radically reducing the transaction costs and expenses associated with individual copyright infringement cases. The Uniform Domain Name Dispute Resolution Policy ("UDNDRP") that the Internet Corporation for Assigned Names and Numbers ("ICANN") has adopted for resolving domain name disputes on the Internet suggests one such nodel. ${ }^{131} \mathrm{~A}$ similar approach, if applied to private copying, could sharply reduce the transaction costs of individual infringement actions and bring more private copiers within the law's reach. Even if sumg every private copier remained impractical, an increase in the number of enforcement actions would increase the risk of a lawsuit for each private copier. With enough of an increase, the enforcement activity might deter private copying generally without any need to resort to unjust punishments. Yet, the danger remains that in order to reduce the transaction costs to an acceptable level, Congress might have to: (1) simplify copyright doctrine to such an extent that the public interest limitations are effectively removed; or (2) turn decisionmaking over to arbitrators who may ignore even a carefully crafted set of rules in favor of more simphistic, pro-plaintiff resolutions. ${ }^{132}$

Moving beyond stopgap extensions of copyright's traditional approach, anotler possibility is to authorize private copying while attempting to compensate copyright owners by collecting levies on sales of the equipment and blank storage inedia that enable such

${ }^{131}$ Internet Corp. for Assigned Names \& Numbers, Uniform Domain Name Dispute Resolution Policy, at http://www.icann.org/udrp/udrp-policy-24oct99.htm (last updated June 4, 2000).

${ }^{132}$ Milton Mueller, Rougl Justice: An Analysis of ICANN's Uniform Dispute Resolution Policy V2.1, at http://dcc.syr.edu/roughjustice.htm (last visited Mar. 23, 2001). In his Executive Summary, Dr. Mueller notes this disjunction between the carefully drafted rules and their application by the arbitrators in particular cases:

On the whole, the UDRP criteria for resolving domain name disputes liave proven to be robust and fair. If applied properly, the policy serves as an effective remedy against abusive registrations while preventing overreaching by trademark liolders. Although a significant number of bad decisions have come out of the process, the worst of them clearly violate or ignore one or more of the UDRP's decision criteria.

Id. 
copying. ${ }^{133}$ Such an approach for videocassette recorders was proposed in the United States following the Sony Corp. decision. ${ }^{134}$ Although rejected in the United States at that time, a levy-based approach has proven popular in Europe. ${ }^{135}$ Beginning with Germany in 1955 with the Grundig decision of the Federal Supreine Court, ${ }^{1.36}$ twelve of the fifteen European Union ("EU") members have imposed, or authorized a collective rights organization to negotiate, a fee (variously defined as a royalty, a tax, or a levy) on the sale of copying equipnient and its associated blank storage media. ${ }^{137}$

${ }^{133}$ In the AHRA, the United States adopted such an approach for digital audio recording devices and associated blank storage media. 17 U.S.C. $\$ \$ 1003-07$ (1994 \& Supp. V 2000). Because the relevant technology has largely failed in the marketplace, however, the royalty provisions have proven to be of little significance.

i4 H.R. 1030, 98th Cong. (1983); see also Lardner, supra note 31, at 251 (discussing background negotiations behind introduction of H.R. 1030).

1" See Deloitte \& Touche, Report on the Collective Management of Copyright in the European Union, at 10 (2000) (on file with the Virginia Law Review Association).

i* BGHZ 18, 44 (F.R.G.); see also Reinhold Kreile, Collection and Distribution of the Statutory Remuneration for Private Copying with Respect to Recorders and Blank Cassettes in Germany, 23 Int'l Rev. Indus. Prop. \& Copyright L. 449, 459-60 (1992) (discussing the effects of the Grundig decision); Juergen Weimann, Private Home Taping Under Sec. 53(5) of the German Copyright Act of 1965, 30 J. Copyright Soc'y 153, 154-56 (1982) (explaining the background of the Grundig decision).

${ }_{17}$ Federal Act on Copyright in Works of Literature and Art and on Related Rights (Aus.) § 42(5)-(7); Law on Copyright and Neighboring Rights art. 55 (June 30, 1994) (Belg.), http://clea.wipo.int (CLEA ID BE003) (last visited Mar. 23, 2001); Act on Copyright $1995 \$ 39$ (June 14, 1995) (Den.), http://clea.wipo.int (CLEA ID DK001) (last visited Mar. 23, 2001); Copyright Act art. 26a (Dec. 22, 1965) (Fin.), http:/clea.wipo.int (CLEA ID FI001) (last visited Mar. 23, 2001); Law on the Intellectual Property Code art. L. 311-1 (Jan. 3, 1995) (Fr.), http://clea.wipo.int (CLEA ID FR003) (last visited Mar. 23, 2001); Law Dealing with Copyright and Related Rights art. 54(1) (June 23, 1995) (F.R.G.), http://clea.wipo.int (CLEA ID DE007) (last visited Mar. 23, 2001); Copyright, Related Rights and Cultural Matters art. 18(3) (Aug. 2, 1996) (Greece), http://clea.wipo.int (CLEA ID GR212) (last visited Mar. 23. 2001); Law No. 93 of Feb. 5, 1992: Provisions for the Benefit of Phonographic Companies and Remuneration for Private Non Profit-Making Reproduction (no date) (Italy), http://clea.wipo.int (CLEA ID IT002) (French language only) (last visited Mar. 23, 2001); Act Amending the 1912 Copyright Act Concerning a Levy on the Reproduction of Recorded Images or Sound Recordings for Personal Use, Study, or Practice $\$ 16(c)$ (May 30, 1990) (Neth.), http://clea.wipo.int (CLEA ID NL004) (last visited Mar. 23, 2001); Code of Copyright and Related Rights art. 82 (Sept. 3, 1991) (Port.), http://clea.wipo.int (CLEA ID PT002) (last visited Mar. 23, 2001); Consolidated Text of the Law on Intellectual Property art. 25(1) (Mar. 6. 1998) (Spain), http://clea.wipo.int (CLEA ID ES070) (last visited Mar. 23, 2001); Act on Copyright in Literary and Artistic Works art. 26k (Swed.) (on file with Virginia Law Review Association); see also Deloitte \& Touche, 
In its May 22, 2001 directive on copyright, the EU approved this approach. In Article 5.b.2, the EU authorized member states to allow private, non-commercial reproduction "on condition that the rightholders receive fair compensation," presumably through levies on equipment used for such private copying. ${ }^{138}$ In the twelve member states that already have levies for private copying, the levies apply to a wide variety of products, including blank audio and VHS cassettes, audio and VHS recorders, photocopiers, digital storage media, and scanners, and have recently been extended to CD burners in Germany. ${ }^{139}$ The funds from the levies are typically collected by one or more collective rights organizations in each member state and are disbursed following a sampling procedure similar to the one the American Society of Composers, Authors, and Publishers ("ASCAP") and Broadcast Music, Inc. ("BMI") use to determine how often a musical work is performed publicly. ${ }^{140}$ Based upon surveys or samples, the collective rights organizations attempt to estimate the likely level of private copying for each individual work and distribute the available funds accordingly. ${ }^{141}$

supra note 135, at 13 (summarizing these fees); Kristi Essick, Computer Tax Plan Sparks French Fury, The Standard Europe, at http://europe.thestandard.com/article/ display/0,1151,14198,00.html (Jan. 24, 2001) (discussing controversy in France over extending copyright levy to imclude non-removable digital recording media, such as computers).

${ }^{133}$ European Union Copyright Directive 2001/29/EC, art. 5.b.2 (May 22, 2001); see also id., pmbl., II 35.250 final at 21-22. The Directive allows member states to grant an exception to the copyright owner's reproduction right for "natural person[s]" to copy for "private use and for ends that are neither directly nor indirectly commercial." Id. The Directive attempts to split the difference between a levy-based approach and an encryption-based approach to the private copying issue by stating that the rightholders must receive "fair compensation which takes account of the application or non-application of technological measures" to control access. Id., art. 5.b.2.

${ }^{139}$ Essick, supra note 137 (following hyperlink to a "country-by-country guide" identifies differing availability and levels for levies on various digital and analogue recording and copyright equipment and storage media); Hewlett-Packard to Pay Royalties on CD Writers, 36 GEMA Newsletter (Dec. 2000), http://www.gema.de/ eng/public/brief36/page4.html (discussing levies on German CD burners).

${ }_{140}$ Compare Deloitte \& Touclie, supra note 135, at 57-60 (describing the methods used by European collective rights organizations to allocate revenue among rightholders), with M. William Krasilovsky \& Sidney Shemel, This Business of Music 197-99 (rev. 7th ed. 1995) (describing similar methods used by ASCAP and BMI to distribute their revenues).

${ }^{141}$ Deloitte \& Touche, supra note 135, at 57-59; see also Kreile, supra note 136, at $463-66$ (discussing royalty distribution in Germany); Weimann, supra note 136, at 166-67 (same). 
To date, these private copying levies have remamed a neartrivial component of the total revenue available for copyrighted works in Europe. Even in Germany, the country with the most extensive system of levies, ${ }^{142}$ the levies collected were only DM 124 million and DM 125 million in 1998 and 1999, respectively (or roughly $\$ 65$ to 75 million each year). ${ }^{143}$ By way of contrast, the total licensing revenue for just one of Germany's collective rights organizations, the Society for Musical Performing Rights and Mechanical Reproduction Rights ("GEMA"), amounted to DM 1.465 billion and DM 1.515 billion in 1998 and 1999, respectively. ${ }^{144}$ If we consider the private copying levies as a component of GEMA's total revenues, GEMA's share ${ }^{145}$ of the private copying levies amounted to roughly $2.6 \%$ of its total revenues both in 1998 and 1999. ${ }^{146}$

Any attempt to expand the levy-based approach to redress private copying inust confront three principal difficulties. First, imposing a levy raises both efficiency and fairness concerns. These concerns arise because copying technology has uses other than pri-

${ }^{142}$ See Kreile, supra note 136 , at 449 ("The following article concentrates on the German view, as the remuneration system in Germany is not only the oldest statutory regulation (since 1965), but since 1985 is also the most comprehensive."); Boris Gröndahl. Taxing Question, The Standard Europe (Jan. 24, 2001), at http://europe.thestandard.com/article/display/0,1151,14146,00.html ("In Germany, the country with the most complete set of such levies ....").

${ }^{14}$ See e-mail from Michael Sandt, Society for Musical Performing Rights and Mechanical Reproduction Rights (Germany) ("GEMA"), to Glynn Lunney (Feb. 22, 2001) (on file with the Virginia Law Review Association) (setting forth the levies collected in Germany for the years 1988 through 1999); see also Kreile, supra note 136, at 456-57 (setting forth levies collected in Germany for the years 1988 through 1990 in identical amounts to those set forth in the e-mail); Gröndahl, supra note 142 (noting that German levies amounted to 90 million euros in 1998). The conversion rate between Deutsch marks and U.S. dollars averaged 1.7597 DM per U.S. dollar in 1998 and ranged from 1.6543 to 1.9522 DM per U.S. dollar in 1999. World Almanac and Book of Facts 2001, at 221; Wall St. J., Jan. 3, 2000, at C1.

14 Reinhold Kreile, Foreword, 162 GEMA News (Dec. 2000), http://www.gema.de/ eng/public/n162/vorwwort.html.

${ }_{14}$ As one of the principal collective rights organizations in Germany, GEMA receives $42 \%$ of the levies from audio recording equipment and almost $21 \%$ of the levies from video recording equipment. See Kreile, supra note 136, at 464-65 (breaking down the distribution of the levies between the various German collective rights organizations as of 1992). I have assumed that GEMA's share of the levies has remained constant since 1992 .

14 For those keeping score at home, the actual numbers work out to be $2.6139 \%$ in 1998 and $2.6109 \%$ in 1999. 
vate copying, yet a levy imposes its price uniformly. The individual who uses a tape recorder to make fifteen copies of another's copyrighted musical works must pay the same levy as the individual who uses the recorder to make a demo tape of her own work. A levy thereby discourages legitimate use of the copying technology (the efficiency concern) and forces individuals who undertake legitimate uses to pay tribute to copyright owners as if they were engaged in private copying (the fairness concern) ${ }^{147}$ These considerations become increasingly significant as the levy increases. If, for example, we were to adopt a levy-based approach as the central means for addressing potential lost revenues in a world where private copying had become a routine means for avoiding the purchase of a work, a levy-based approach might need to impose a levy sufficient to equalize, for example, the costs of privately copying a popular $C D$ and purchasing the $C D$ at the market price. Rather than pay only a few dollars for ten blank CDs, a consumer might have to pay ten dollars for one $C D$ in order to provide the funds necessary to compensate the copyright owner for the lost sales revenue. At such a high level, a levy could prove both fair and efficient only so long as nearly everyone is using the blank CDs for the same purpose. If substantial legitimate uses remain, the inefficiency and unfairness of such a large levy become palpable.

Second, such a levy discourages the creation and dissemination of new distribution technologies. With the introduction of innovative copying technology, a manufacturer is likely to enjoy solne Inarket power with the new technology, whether as a result of a patent or simple lead-time advantage. This market power offers the manufacturer the opportunity to earn rents on the new technology that serve in turn as the incentive for developing and producing the new technology. If a levy is imposed on such technology, the levy will increase the price of the technology to consumers, creatimg an artificial price increase and its resulting in-

${ }^{147}$ In Germany, proponents of the levy-based approach have countered this argument by suggesting that "it is unlikely that the machine during its whole lifetime will never be used in infringing ways..."."Weimann, supra note 136, at 167 . Of course, this still leaves open the very real possibility that individuals will use their respective machines to quite different extents for private copying. 
efficiencies, as it would for existing technologies. ${ }^{148}$ The levy will also reduce the rents available to the manufacturer for introducing the new technology. With a levy, part of the rents otherwise available to the manufacturer will be collected through the levy and turned over to copyright owners. ${ }^{199}$ Reducing the rents available reduces, in turn, the manufacturer's incentive to innovate. Reduced incentives, together with an increased price to consumers for the new technology, are likely to slow the creation and introduction of new copying and distribution technologies.

While consumer groups and electronics manufacturers have advanced these first two considerations as reasons to oppose a levybased approach, copyright owners have advanced a third. Their concern is that a levy-based approach expressly authorizes private copying. ${ }^{150}$ Such an express authorization could move private copying from the margins into the inainstream, converting private copying from a minor annoyance into a major threat to copyright revenues. At the same time, a levy-based approach would also limit the ability of copyright owners to price discriminate and otherwise

Iax In contrast to the perfectly competitive market, the price increase resulting from a levy in a monopoly market may yield a price increase to consumers somewhat lower or higher than the amount of the levy. Hal. R. Varian, Intermediate Microeconomics: A Modern Approach 419 (5th ed. 1999) (noting that when a quantity tax is imposed on a monopolist it "may increase the price by more or less than the anount of the tax").

${ }^{14}$ Before the levy, the manufacturer had presumably set a price that maximized its available profit. If the levy takes the form of a pure profits tax, the levy will not change the manufacturer's optimal market price or output. Id. at 420 . As a result, such a levy would come dollar-for-dollar out of the manufacturer's pocket. In contrast, a per unit levy would increase the price the manufacturer should charge to maximize profits. Id. at 418-20. The rents available at this new price will be lower than the pre-levy rents, and moreover the inanufacturer will have to turn over a share of the reduced rents as its part of the levy.

" See Deloitte \& Touche, supra note 135, at 13 (noting that along with levies, "[a]11 Member States provide for a form of involuntary license for reproductions at home of sound and audiovisual recordings for private purposes"); Mark Ward, A Tax on Music Tracks, BBC News Online, at http://news.bbc.co.uk/hi/english/sci/tech/ newsid_1120000/1120199.stm (Jan. 17, 2001) ("'We decided against it im the UK,' she said, 'because a levy on blank tapes would seein to legalise taping, and the money raised from any levy would have been a drop in the ocean of lost royalties.") (quotimg a spokeswoman for the British Phonographic Institute). Copyright owners are also concerned that a lack of competition, supervision, and transparency in the operation of collective rights organizations raises doubts as to any systein that forces them to rely more heavily on such organizations for their revenues. Deloitte \& Touche, supra note 135 , at $28-34,44-55$. 
price their works as they see fit. With a levy-based approach, responsibility for setting prices would no longer reside with copyright owners alone, subject only to the market; the government and equipment manufacturers would also play a central role. Whether set by statute or by negotiation with the manufacturers, copyright owners worry that the resulting levies will prove inadequate to compensate them for lost sales should private copying become widespread.

Although not fatal, ${ }^{151}$ these difficulties with a levy-based approach are serious and suggest the need to consider one final alternative: the Honor System.

\section{The Honor System}

In his Philosophy of Right, ${ }^{152}$ Hegel articulated an honor-based approach for controlling plagiarism: "Hence plagiarism would have to be a matter of honour and be held im check by honour."153 Yet, in the rush to shut down Napster and MP3.com, very little serious attention has been paid to the possibility that American consuiners might be trusted to regulate theinselves. Far too inuch attention has been paid to the assumption that if consumers can obtain copies for free, the vast majority of them will do so. ${ }^{154}$

${ }^{151}$ See infra text accompanymg notes 312-28.

${ }^{152}$ Hegel's Philosophy of Right (T.M. Knox trans., Oxford Press. 1967) (1952).

${ }^{153}$ Id. II 69 , at 56 . To place the statement in context, the entire passage reads:

Moreover, the purpose of a product of mind is that people other than its author should understand it and make it the possession of their ideas, memory, thinking, \&c.... The result is that they inay regard as their own property the capital asset accruing from their learning and may claim for themselves the right to reproduce their learning in books of their own.... Now to what extent does the new form which turns up when something is expressed again and again transform the available stock of knowledge, and in particular the thoughts of others who still retain external property in those intellectual productions of theirs, into a private mental property of the individual reproducer and thereby give him or fail to give him the right to make them his external property as well? To what extent is such repetition of another's material in one's book a plagiarisın? There is no precise principle of determination available to answer these questions, and therefore they cannot be finally settled either in principle or by positive legislation. Hence plagiarisin would have to be a matter of honour and be held in check by honour.

Id. II 69 , at 55-56.

154 When a group of motion picture studios sued a sixteen-year-old Norwegian for distributing the DeCSS program, Jack Valenti of the Motion Picture Association of 
As part of the development of the free rider concept, economists often begin with the assumption that each consumer makes decisions to maximize her ${ }^{155}$ utility based upon a narrow view of rational self-interest. Under this narrow view, a consumer will typically choose to free ride. ${ }^{156}$ Free riding enables her to obtain access to the public good without paying her pro rata share of the public good's cost and leaves her free to devote those resources elsewhere. Also, as part of this initial development of the free rider concept, economists often assume that cooperation is unlikely, especially as the number of participants (and hence potential free riders) increases. Through these assumptions, economists created a theoretical framework in which to examine and develop the concept and potential consequences of free riding largely free of real world complications. Although these assumptions were therefore convenient in the initial theoretical development of the free rider concept, economists have also recognized that these assumptions are unlikely to prove generally accurate ${ }^{157}$ Self-sacrifice, coopera-

America insisted that "[n]obody is going to make very expensive movies if they can't protect them." Sixteen-Year-Old Boy in Norway Unlocks Computer Code That Lets Anyone Make Illegal Copies of Movies, ABC World News This Morning, Mar. 10, 2000, LEXIS, News Library, ABC News File. Valenti's statement implicitly equates the availability of DeCSS with widespread free copying.

"I am using the female pronoun in the text as the universal pronoun, not to identify the sex of the actor at issue. In using the female pronoun, I do not mean to invoke those experimental studies that have shown a difference in free riding behavior between men and women. See, e.g., Kelly M. Brown \& Laura O. Taylor, Do as You Say, Say as You Do: Evidence on Gender Differences im Actual and Stated Contributions to Public Goods, 43 J. Econ. Behav. \& Org. 127 (2000); Jamie BrownKruse and David Hummels, Gender Effects in Laboratory Public Goods Contribution: Do Individuals Put Their Money Where Their Mouth Is?, $22 \mathrm{~J}$. Econ. Behav. \& Org. 255 (1993); Clifford Nowell \& Sarah Tinkler, The Influence of Gender on the Provision of a Public Good, 25 J. Econ. Behav. \& Org. 25 (1994).

1\% William H. Oakland, Theory of Public Goods, in 2 Handbook of Public Economics 485, 514 (Alan J. Auerbach \& Martin Feldstein eds., 1987) ("In markets for private goods, when the number of participants is large, individual actors become price-takers. In public good markets, on the other hand, people become quantitytakers. Consequently, no agent feels that he/she can influence the amount of public good which is made available. The rational agent, therefore, will attempt to 'free ride' on the public good supplies of others.").

${ }^{19}$ Amartya K. Sen, Rational Fools: A Critique of the Behavioral Foundations of Economic Theory, in Beyond Self-Interest 25, 37 (Jane Mansbridge ed., 1990) ("The" purely economic man is indeed close to being a social moron. Economic theory has been much preoccupied with this rational fool decked in the glory of lis one allpurpose preference ordering. To make rooin for the different concepts related to his behavior we need a more elaborate structure."); see also Howard Margohs, 
tion, and charitable contribution, just to name a few examples, are all extremely common and tend to refute, at least to some extent, the free rider theory. ${ }^{158}$

Looking at free riding as an empirical, real world phenomenon, it is far less clear that free riding will prove both substantial and inevitable. ${ }^{159}$ Over the last twenty years, economists and sociologists have conducted extensive empirical research into the question of free riding and the private provision of public goods. ${ }^{160}$ Through

Selfishness, Altruism, and Rationality 11 (1982) ("Almost no economist would deny the possibility of altruism in rational choice.").

${ }_{158}$ E.g., Dipak K. Gupta et al., Group Utility in the Micro Motivation of Collective Action: The Case of Membership in the AARP, 32 J. Econ. Behav. \& Org. 301, 302 (1997):

However, the fact of life is that people, across time, space, and culture take part in collective actions of all sorts, often at extreme costs, risking economic wellbeing, reputation, and even personal safety. It is, therefore, well accepted after two decades of intense analyses that the solution to this logical quagmire lies, not with the rationality of the actor taking part in a collective action, but with the definition of rationality.

${ }^{159}$ See John O. Ledyard, Public Goods: A Survey of Experimental Research, in The Handbook of Experimental Economics 111, 121 (John H. Kagel \& Alvin E. Roth eds., 1995) ("Economists and game-theorists argue that the hypothesis of selfish beliavior is the only viable one as an organizing principle, yet they also contribute to public television and vote in elections.").

${ }^{160}$ For a survey of the literature, see generally Douglas D. Davis \& Charles A. Holt, Experimental Economics 317-43 (1993); Ledyard, supra note 159. To sample some of the work in the field, see Simon P. Anderson et al., A Theoretical Analysis of Altruism and Decision Error in Public Goods Games, 70 J. Pub. Econ. 297 (1998); James Andreoni, Cooperation in Public-Goods Experiments: Kindness or Confusion?, 85 Am. Econ. Rev. 891 (1995) [hereinafter Andreoni, Cooperation in Public-Goods Experiments]; James Andreoni, Why Free Ride? Strategies and Learning in Public Goods Experiments, 37 J. Pub. Econ. 291 (1988); James Andreoni \& John H. Miller, Rational Cooperation in the Finitely Repeated Prisoner's Dilemma: Experimental Evidence, 103 Econ. J. 570 (1993); Jordi Brandts \& Arthur Schram, Cooperation and Noise in Public Goods Experiments: Applying the Contribution Function Approach, 79 J. Pub. Econ. 399 (2001); C. Bram Cadsby \& Elizabeth Maynes, Gender and Free Riding in a Threshold Public Goods Game: Experimental Evidence, 34 J. Econ. Behav. \& Org. 603 (1998); Charles Bram Cadsby \& Elizabeth Maynes, Voluntary Provision of Threshold Public Goods with Continuous Contributions: Experimental Evidence, 71 J. Pub. Econ. 53 (1999) [hereinafter Cadsby \& Maynes, Voluntary Provision]; R. Mark Isaac et al., Public Goods Provision in an Experimental Environment, 26 J. Pub. Econ. 51 (1985); R. Mark Isaac et al., Divergent Evidence on Free Ridmg: An Experimental Examination of Possible Explanations, 43 Pub. Choice 113 (1984) [hereinafter Isaac et al., Divergent Evidence]; Susan K. Laury et al., Anonyinity and the Voluntary Provision of Public Goods, 27 J. Econ. Behav. \& Org. 365 (1995); Gerald Marwell \& Ruth E. Ames, Economists Free Ride, Does Anyone Else? Experiments on the Provision of Public Goods, IV, 15 J. Pub. Econ. 295 (1981); Gerald Marwell \& Ruth E. Ames, 
this research, they have identified at least five considerations that may lead individuals to contribute voluntarily to a public good:

(1) Altruism: Some imdividuals contribute to the production of a public good because they derive satisfaction from the satisfaction others experience from the good's creation; ${ }^{161}$

(2) The "Warm Glow" Effect: Some individuals contribute to the production of a public good because they derive satisfaction directly from contributing, ${ }^{162}$

(3) Long-Term Self Interest: Some individuals contribute to the production of a public good because they recognize that their contributions help ensure the work's creation, from which they derive satisfaction; ${ }^{163}$

(4) Reputation: Some individuals contribute to the production of a public good because they derive satisfaction from their resulting reputation: $;{ }^{164}$ and

(5) Informal Cooperation: Some individuals contribute to the production of a public good because groups develop informal mechanisms to encourage such contributions, and the individual derives satisfaction from being a member of tlie group. ${ }^{165}$

Experiments on the Provision of Public Goods, I: Resources, Interest, Group Size, and the Free-Rider Problem, 84 Am. J. Soc. 1335 (1979); Gerald Marwell \& Ruth E. Ames, Experiments on the Provision of Public Goods, II: Provision Points, Stakes, Experience and the Free-Rider Problem, 85 Am. J. Soc. 926 (1980); Thomas R. Palfrey \& Jeffrey E. Prisbrey, Anomalous Behavior in Public Goods Experiments: How Much and Why?, 87 Am. Econ. Rev. 829 (1997); Paul Pecorino, The Effect of Group Size on Public Good Provision in a Repeated Game Settimg, 72 J. Pub. Econ. 121 (1999); Daniel Rondeau et al., Voluntary Revelation of the Demand for Public Goods Using a Provision Point Meclianisın, 72 J. Pub. Econ. 455 (1999).

${ }^{16 i}$ Andreoni \& Miller, supra note 160 , at 578-82 (finding evidence that altruism exists in experiment of finitely repeated Prisoner's Dilemma). But see Palfrey \& Prisbrey, supra note 160 , at 830 (defining an altruistic effect where "a subject's utility is increasing, not only im his or her own payoff, but also in the total group payoff," but failing to find such an effect in their experiments).

${ }_{102}$ Palfrey \& Prisbrey, supra note 160, at 830 ("Warm-glow preferences mean that the act of contributmg, independent of how mucl it increases group payoffs, increases a subject's utility by a fixed amount.").

${ }^{162}$ Cadsby \& Maynes, Voluntary Provision, supra note 160, at 54 (noting that the use of a threshold total contribution level "may act as a focal point for cooperation").

im Andreoni \& Miller, supra note 160, at 582 (finding evidence tliat "subjects appear very willing to build reputations for altruisms" within context of a finitely repeated Prisoner's Dilemma game).

${ }^{165}$ E.g., Robyn M. Dawes, Social Dilemmas, 31 Ann. Rev. Psycliol. 169, 185 (1980) (discussing an experimental result finding that only thirty-one percent contributed without communication among the subjects, while seventy-two percent contributed 
Although researchers have used a variety of approaches to explore consumer behavior on the free rider/public good issue, one standard approach is known as the threshold public goods game. ${ }^{166}$ In a threshold public goods game, individuals in a group must decide whether to contribute voluntarily to the provision of a public good. If enough contributions are inade, the public good is provided. If not, the public good is not provided and individuals lose any contributions they have made. All individuals are better off if the public good is provided, but individuals who do not contribute are better off than those who do contribute whether the public good is provided or not.

Even where the payoffs are structured to generate a dominant strategy for all players not to contribute, "[m]ost players in this game violate their one-shot dominant strategy, with many contributing upwards of half their endownent."167 The near-umiform conclusion from repeated studies is that voluntary contribution rates to the production of public goods are significantly different from zero. ${ }^{165}$ Moreover, voluntary contributions occurred in these experiments despite the tendency of the artificial and controlled laboratory setting to "eliminat[e] a large annount of subjects' natu-

with communication among the subjects); Gupta et al., supra note 158, at 318 (finding that "group-based utilities in the preference for public goods appear to offer a significant explanation for AARP membership").

${ }_{166}$ This description comes from Cadsby \& Maynes, Voluntary Provision, supra note 160 , at 53-54.

${ }^{167}$ Palfrey \& Prisbrey, supra note 160 , at 830 ; see also Andreoni, Cooperation in Public-Goods Experiments, supra note 160, at 892 ("In a ten-period iterated game, subjects generally begin by contributing about half of their endownents to the public good. As the game is iterated, the contributions 'decay' toward the dominant strategy level and stand at about $15-25 \%$ of the endowment by the tenth iteration.") (citation omitted).

${ }^{16 s}$ Andreoni, Cooperation in Public-Goods Experiments, supra note 160, at 892 ("These experiments typically find that subjects are sensitive to free-riding incentives and are generally closer to the free-riding outcome than the Pareto-efficient outcome."); Ledyard, supra note 159, at 112-13 (summarizing research results suggesting voluntary contribution rate in the range of forty to sixty percent). "Nonetheless, cooperation is still above that which would validate the theory [of free riding]." Andreoni, Cooperation in Public Goods Experiments, supra note 160, at 892. Andreoni also notes that some players, who may have been mistaken as to the dominant stategy, contributed by mistake in the initial rounds of a repeated game and then reduced their mistake-based contributions in later rounds. Id. at 897 . Yet he found that the reductions in mistaken contributions as a result of learning were "replaced by a growth in kindness, leaving total cooperation fairly stable." Id. at 900. 
ral tendency to be cooperative." ${ }^{169}$ Although the studies do not suggest that free riders can never pose a problem, ${ }^{170}$ they have shown that voluntary contribution rates can reach the level necessary to ensure efficient production of a public good. ${ }^{171}$

Evidence from the real world tends to confirm these studies ${ }^{172}$ and suggests that the honor system is a practical alternative to more formal legal control in this area. For example, when Stephen King offered his serial novel, The Plant, on the Internet, he rehed on voluntary contributions to fund the endeavor and stated that he would provide future installments only if the voluntary contribution rate remained above a certain threshold level. ${ }^{173}$ The contribution rate hovered at over seventy percent for the first few installments, as consumers voluntarily contributed in order to ensure the availability of future installments. ${ }^{174}$ The contribution rate fell below King's threshold only when he announced the series' end

${ }^{104}$ Andreoni, Cooperation in Public-Goods Experiments, supra note 160, at 900.

17" Robyn M. Dawes \& Richard H. Thaler, Anomalies: Cooperation, 2 J. Econ. Persp. 187, 196 (1988) ("It is certainly true that there is a 'free rider problem.'... On the other hand, the strong free rider prediction is clearly wrong-not everyone free rides all of the time."); Isaac et al., Divergent Evidence, supra note 160, at 140 ("[F]ree riding is neither absolutely all pervasive nor always nonexistent.... The extremes of strong free riding and near-Lindahl optimal behavior can and do occur.").

${ }^{17}$ Cadsby \& Maynes, Voluntary Provision, supra note 160 , at 68-69 ("[O]ur experiments provide many examples where groups move toward cooperation rather than free-riding over time. Indeed, our results indicate that a deterioration in the level of contributions is a special case, occurring only when the incentives to reach an efficient equilibrium are relatively low. The more general result is that contributions move toward a Nash equilibrium over repeated rounds of a pubhic goods game."); Ledyard, supra note 159, at 156-57 (summarizing studies showing that with communication permitted between group members, contribution rates increased to between seventy and ninety percent, even over repeated periods); Rondeau et al., supra note 160, at 468 ("Using large groups im an induced value framework, we have shown that the provision point mechanism with money-back guarantee and proportional rebate of excess contributions can closely approximate demand revelation.").

17 One particularly interesting real-world study is James C. Murdoch \& Todd Sandler, The Voluntary Provision of a Pure Public Good: The Case of Reduced CFC Emissions and the Montreal Protocol, 63 J. Pub. Econ. 331 (1997) (finding that the Montreal Protocol merely formalized voluntary reductions in CFC emissions that countries had previously and voluntarily undertaken).

${ }^{17}$ Jerry Harkavy, King-Sized Experiment in Publishing Inconclusive, Commercial Appeal (Memphis), Dec. 11, 2000, at B3, available at LEXIS, News Library, The Commercial Appeal File.

${ }^{14}$ Id. (noting that "[a]t the outset, about 75 percent of readers obeyed the honor system"). 
and removed the incentive for consumers to contribute. ${ }^{175}$ King's experiment also suggests the viability of informal cooperation in this context. When the contribution rate threatened to fall below the threshold King had identified as necessary for additional installments, consumers who placed a higher value on the series' contimuation stepped in and offered additional contributions. ${ }^{176}$

Although King's faine makes The Plant something of a special case, evidence from the field of computer software provides more general support for the notion that consumers can regulate themselves. For computer prograins, private copying is already an option for obtaining unauthorized copies. Yet, a report sponsored by the Business Software Alliance estimated that more than seventy percent of the copies in circulation from 1995 to 1999 in the United States were obtained legitimately. ${ }^{17}$

Although a seventy percent contribution rate might seem too low to encourage the production of copyrighted works, contribution rates as low as fifty percent may be sufficient to ensure an optimal supply. Assume that a copyright owner contemplating production faces a downward-sloping, linear demand curve with constant marginal costs. ${ }^{178}$ If the author holds a monopoly position by virtue of a copyright (as reflected in the assumption of a downward-sloping demand curve), ${ }^{179}$ she maximizes profit by producing

175 Jonathan Lambeth, King's Plant wilts as readers fail to pay, Daily Telegraph (London), Dec. 7, 2000, at 3. After noting that contribution rates fell from seventy-six percent for the first three installments to below fifty percent for installments four and five, Stephen King stated, "It may be that people are steahing this particular imstallment simply because they know the story is gomg to stop anyway." Id.

${ }^{176}$ Dave Cosgrave, King's New E-Publishing Model, eBusiness Journal, Oct. 1, 2000; Don O'Briant, 'Plant' Fans Pay Their Way, Times Union (Albany, NY), Aug. 27, 2000 , at $\mathrm{J} 4$ ("Amazon.com, which is processing payments for King, reports that some readers have been sending in extra nioney for the $\$ 1$ imstallments-fronı $\$ 2$ to $\$ 20$-to make up for deadbeat downloaders."), available at LEXIS, News Library, The Times Union File.

17 Int'l Planning \& Research Corp., 1999 Global Software Piracy Report 6 (2000), at http://www.bsa.org/usa/globallib/piracy/1999_Piracy_Stats.pdf (May 2000).

${ }_{178}$ These assumptions are entirely typical. See, e.g., Varian, supra note 148, at 416417 (assuming a downward-sloping limear demand curve); Landes \& Posner, supra note 106 , at $327 \&$ n.4 (assuming a downward-sloping demand curve); id. at 333 (assuming constant nuarginal costs).

${ }^{179}$ Commentators have debated whether, and if so to what extent, copyright creates nuarket power. Compare Lunney, supra note 120 , at 519 (recognizing that copyright creates market power generally for all authors; the extent of market power for any given author is a neere question of degree), and Willianı $R$. Johnson, The Economics 
additional copies of her work up to the point where marginal revenue equals marginal cost. She will then set her price at the corresponding market-clearing levels. ${ }^{180}$ In contrast, if the market for copies of the copyright owner's work had been perfectly competitive, the owner would continue to produce additional copies until marginal cost equalled dernand. Figure 1 illustrates these relationships, where $Q c$ and $P c$ represent the author's output and pricing decisions under perfect competition, and $Q m$ and $P m$ represent her output and pricing decisions under monopoly.

of Copying, 93 J. Pol. Econ. 158, 161 (1985) ("There are many sellers of originals, each with the monopoly power that stems from the fact that his work is not a perfect substitute for the others."), with Paul Goldstein, Copyright, 55 Law \& Contemp. Probs. 79, 84 (1992) (suggesting that copyright does not generally create market power), and Tom W. Bell, Fair Use v. Fared Use: The Impact of Automated Rights Management on Copyright's Fair Use Doctrine, 76 N.C. L. Rev. 557, 588 n.142 (1998) (arguing that "copyright owners do not necessarily enjoy monopoly power"). Most commentators readily admit that popular authors enjoy some considerable degree of market power, reflected in the variety of price discrimination practices that copyright owners employ. E.g., Aaron Xavier Fellment, Copyright Misuse and the Limits of the Intellectual Property Monopoly, 6 J. Intell. Prop. L. 1, 13 (1998); Wilham W. Fisher III, Reconstructing the Fair Use Doctrine, 101 Harv. L. Rev. 1659, 1702-03 (1988). But see Donald S. Chisum \& Michael A. Jacobs, Understanding Intellectual Property Law $\$ 1 C$, at 1-7 (1992) ("Giving exclusive rights to an author or inventor is no more a monopoly or anticompetitive than other species of real or personal property."). Commentators question whether such market power extends to less popular authors, however. E.g., Fisher, supra, at 1702 . While reduced popularity likely coincides with reduced market power, the fundamental purpose of copyright is to enable all authors to price their works somewhat above marginal cost so that they have some opportunity to recover their authorship investment. See generally Yochai Benkler, An Unhurried View of Private Ordering in Information Transactions, 53 Vand. L. Rev. 2063, 2068 (2000) ("But remember that information goods, if they are sold at a positive price at all, are being sold at a price above their marginal cost. To the extent that we observe a transaction for an information good at a positive price, we are observing a situation where the seller has 'market power' to engage at least to some extent in above marginal cost pricing."). The ability of less popular authors to price in excess of marginal cost may derive more froin following the prices that popular authors set than the result of any imherent market power of their own. Nevertheless, to the extent even less popular authors can and do price in excess of their marginal costs, they will follow the monopolist's profit-maximizing rule in setting that price. As a result, so long as their demand curve is linear and their inarginal costs constant, they too will sell only half the number of copies that would be sold in a competitive market.

1w. E.g., Varian, supra note 148, at 414-16. 
Figure 1. Comparison of monopoly and competitive output and pricing.

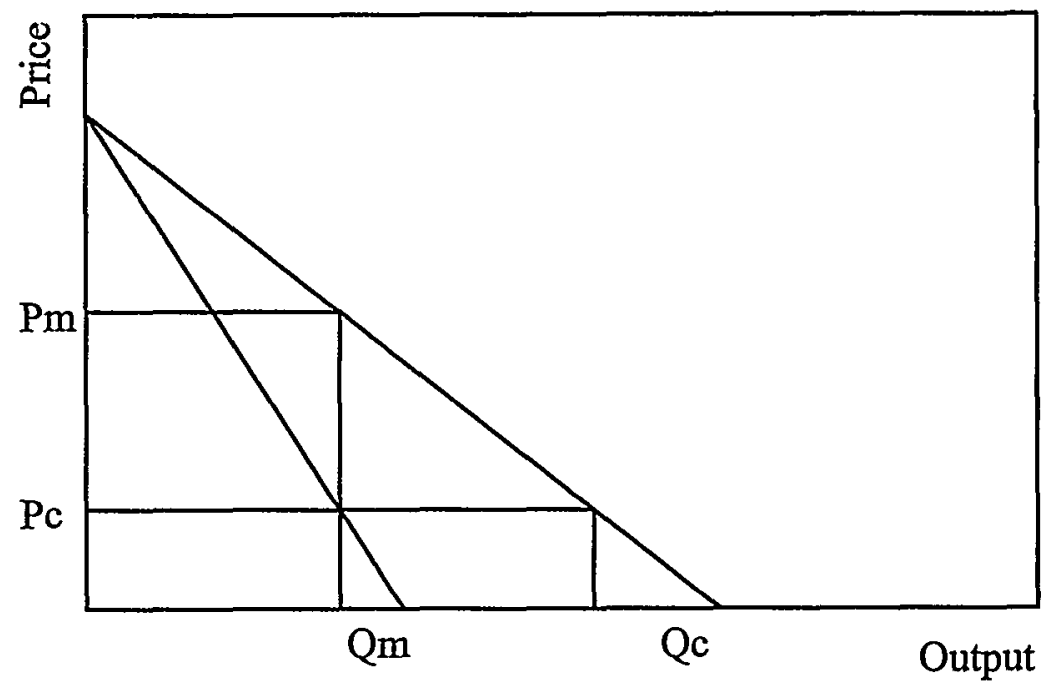

The result under these assumptions is that the copyright owner will maximize her profit by selling exactly half the number of copies that she would have sold in a perfectly competitive market. ${ }^{181}$ This pricing strategy means that for every consumer who willingly pays the copyright owner's price, there is another who would have paid the work's competitive price, but who is unwilling to pay the supra-competitive price the copyright owner is charging. Because these consumers are unwilling to pay the copyright owner's price in

${ }_{181}$ Professor Varian provides the mathematical background for the proof of this statement:

Suppose that the monopolist faces a linear demand curve $p(y)=a-b y$. Then the revenue function is $r(y)=p(y) y=a y-b y^{2}$, and the marginal revenue function is $M R(y)=a-2 b y$.

$\cdots$

Note that the marginal revenue function lias the same vertical intercept, $a$, as the demand curve, but it is twice as steep.

Id. at 416-18. Recall that marginal costs are constant. Suppose that they are equal to $k$. Then the intersection of the demand curve and marginal cost occurs when $a-b y=$ $k$, i.e. when $y_{c}=(a-k) / b$. Similarly, the intersection of the marginal revenue curve with marginal cost occurs when $a-2 b y=k$, i.e., when $y_{m}=(a-k) / 2 b$. But $y_{m}$ is just lalf of $y_{c^{*}}$. So $Q m$ is half of $Q c$. 
any event, the copyright owner would see no reduction in her revenue, ceteris paribus, even if every one of them obtained an unauthorized copy of the work through private copying. ${ }^{122}$ Nor would allowing unpaid access for these consumers increase the price of copies for those consumers willing to pay for the work. Because the copyright owner's optimal price is a function solely of her marginal cost, she cannot increase the profit associated with her work by attempting to redistribute any part of a free rider's pro rata share of the work's fixed costs to her paying customers. ${ }^{183}$

As a result, so long as the free riding is concentrated among those unwilling to pay in any event, ${ }^{184}$ contribution rates as low as fifty percent are fully consistent with the efficient private market production of creative works. ${ }^{185}$ In that light, the more than seventy

${ }_{182}$ I have suggested elsewhere that free riding may present a competitive challenge to the copyright owner and force her to reduce her price generally. See Glynn S. Lunney, Jr.. Trademark Monopolies, 48 Emory L.J. 367, 448-52 (1999); see also infra text accompanying notes 323-28 (discussing free riding's coinpetition-mducing effects under a levy system).

${ }^{187}$ This sharply differentiates unauthorized copying froin theft. With theft, the thief deprives the owner of the tangible article itself, including the item's marginal cost (and market price in a perfectly competitive inarket). In contrast, with unauthorized copying, the copier, not the copyright owner, bears the marginal cost of the unauthorized copy. As a result, if a producer experienced a fifty percent theft rate, where for every two units produced, one was stolen, the marginal cost of the stolen unit would have to be added to the price of the sold unit. In contrast, if a copyright owner experiences a fifty percent unauthorized copynig rate, where for every copy sold, a second is privately copied, the copyright owner incurs no marginal cost for the second copy and so would not change the price of the sold copy. But see Information Infrastructure Task Force, Working Group on Intellectual Property Rights, Intellectual Property Rights and the National Information Infrastructure 230 (Sept. 1995 ) (asserting that "[c]onsumers of copyrighted works pay for the acts of mfringers; copyright owners have suggested that the price of legitimate copies nay be higher due to infringement losses suffered by copyright owners").

Given that unauthorized copies may be of lower quality and often lack some of the features associated with an authorized copy, such as liner notes, free updates, and warranty service. we should expect free riding to be concentrated among those unwilling to pay for an authorized copy.

is If the private copying entails a marginal cost for additional copies less than the marginal cost associated with authorized distribution of additional copies, then voluntary contribution rates below fifty percent could be consistent with the optimal supply of creative works. Similarly, if we vary the assumptions of a straight-hine demand curve or a flat inarginal cost curve, the minimum contribution rate necessary to ensure that efficient activity levels are reached may vary. Moreover, economists have developed a variety of models as alternatives to the perfect conipetition and monopoly cases. If one of these other models more accurately reflects the sort of 
percent contribution rates that both King and the software industry have achieved indicate that an effective external control against private copying may prove unnecessary. Consumers can regulate themselves. ${ }^{186}$ All the public needs is some general statement, such as that found in copyright law, reflecting and reinforcing the principle that excessive unauthorized copying is improper.

"competition" found in copyrighted works, the fifty percent free-riding threshold may
be too high. For example, if we analyze the issue as a Stackleberg equilibrium
between a leader and a follower offering identical products and competing on
quantity, production levels in the market under our assumptions would rise to
seventy-five percent of the perfectly competitive output level. See Varian, supra note
148 , at $468-75$. In such a case, free riding in excess of twenty-five percent might prove
too high to ensure efficient production levels. ${ }^{186}$ Moreover, the same free-rider problem that might lead to an underproduction of copyrighted works may also ensure that private copying proves either self-limiting or addressable through traditional copyright. For private sharing to occur, someone must undertake the expense of loading the work on her coinputer and then open her computer to others, with consequential risks to security and her bandwidth usage. With small group sharing, peer pressure within the group may be sufficient to ensure that each person contributes to the works uploaded and available for copying. For small groups, the security risks and costs associated with offering the work to others for copying are minimal. Of course, in such small groups, that same peer pressure is also likely to increase the group's paying demand for works as well. As a result, private copying within small groups will hkely be harmless or perhaps even beneficial to copyright revenues. For very large groups, the bandwidth and security costs entailed in inaking a work available for others to copy are significantly higher. For that reason, individuals within the group will likely attempt to free ride and wait for others to make materials available for copying. As a result, private copying within large groups is itself subject to potential free-rider problems that will limit its practical extent. Eytan Adar \& Bernardo A. Huberman, Free Riding on Gnutella, First Monday (Oct. 2000), at http://www.firstmonday.dk/issues/issue5_10/adar/index.html (last visited August 7, 2001). For such large groups, a central registry may prove essential for widespread private copying to occur. Jordan Ritter, Why Gnutella Can't Scale. No, Really, at http://www.darkridge.com/ jpr5/doc/gnutella.htm (last visited Mar. 23, 2001) (describing how Gnutella imposes excessive bandwidth demands on its users because, in the absence of a central file hist, Gnutella must search each system for a file to determine whether the file is present and typically searches numerous systems for a file before finding it). Yet, such a central registry would arguably bring large group private copying within the reach of traditional copyright through the vicarious or contributory infringement doctrines. As between large group and small group private copying, the question is whether there is a group size sufficiently small to avoid the free-rider problem that arises with private copying, yet sufficiently large that the private copying reduces the group's paying demand for copyrighted works as a whole. To the extent that the incentive to free ride and the peer pressure not to free ride represent two sides of the same coin, there is every reason to expect, as a general rule, that if the group is small enough to encourage any significant degree of sharing, it is also sinall enough for the sharing to increase the group's paying demand for works. 


\section{PRIVATE COPYING AND THE PUblic INTEREST}

To determine whether some of these alternatives, either individually or in combination, might better reflect copyright's public spirit, this Part returns to the key short-term legal question: Should courts read the DMCA's anti-circumvention provisions hiberally or strictly? On the one hand, a liberal reading allows more extensive access to decryption technology for those likely to have a fair use for such technology, but puts such technology into the hands of those intending unlawful uses as well. A strict reading, on the other hand, restricts access to decryption technology and ensures nearcomplete protection against private infringement, but bars otherwise fair or lawful uses of an encrypted work.

A balancing of these two concerns, weighing the potential lost access from strong encryption against the potential lost incentive from weak encryption in line with copyright's traditional incentives-access paradigm, would plausibly weigh in favor of restricting access to decryption technology. Even if restricting access led to over-protection and increased prices for creative works generally, society would presumably still prefer to have the works, albeit at a higher price, than risk not having them at all.

As discussed at the outset, however, two considerations suggest a need to rethink this initial conclusion. First, this conclusion rehes on an unspoken and largely unexamined assumption that more revenue for any given copyrighted work will yield inore works generally. In the case of widespread private copying, this assumption will likely prove untrue. So long as the level of private copying increases with the popularity of a work, private copying is unlikely to reduce creative output at the inargins. Instead, it will simply enable consumers to recapture a portion of the excess incentives otherwise associated with the production of more popular, non-inarginal works. Moreover, by reducing these excess incentives, private copying will tend to reduce the corrupting influence that excess incentives would otherwise exert on the authorship process. As a result, attempting to resolve the issue by balancing the relative costs of over- and under-protection, as the traditional analysis defines them, obscures the true issues. Second, the traditional analysis ignores the important role that private copying can play as a form of civil disobedience. Broader copyright protection benefits a concentrated, well-organized constituency, copyright owners, at 
the expense of a dispersed group, consumers generally. Therefore copyright owners will have a decided advantage in the political battle over copyright's proper scope. This advantage is evident in the radical expansion in copyright protection that has occurred over the past two hundred years. Furthermore, although the Constitution entrusts the judicial branch with the responsibility for policing copyright's boundaries, courts have largely abdicated that role. As a result, civil disobedience may offer the only effective means for ordinary consumers to express their political discontent with copyright's excessive scope.

\section{A. Protection, Excess Incentives, and the Margins of Creativity}

An examination of the Constitution and its limitation on congressional authority in the field of copyright legislation is necessary to define the concept of excess imcentives more precisely. As Article I, Section 8, Clause 8 states, Congress may enact a copyright statute only to secure "the Progress of Science." Although the exact parameters of this limitation are not clear, one aspect of the limitation shines through: Copyright may not serve solely or primarily to enrich copyright owners. The public must receive something in return. ${ }^{188}$

Copyright proponents insist that copyright serves such a public purpose by providing a needed incentive for the creation of works of authorship. Because works of authorship are relatively easy to copy, proponents insist, too few works will be created in the absence of protection. Only by protecting these works against copying, proponents continue, can we ensure the public an adequate supply of creative works. ${ }^{189}$ The heart of this justification has changed hittle since first articulated by the Stationers' Company:

And further if priuileges be revoked no bookes at all shoulde be prynted, within shorte tyme, for comonlie the first prynter is at charge for the Authors paynes, and somme other suche like extraordinarie cost, where an other that will print it after hym, commeth to the Copie gratis, and so maie he sell better cheaper

187 U.S. Const. art. I, § 8, cl. 8.

${ }^{18}$ See sources cited supra note 4.

${ }^{18}$ E.g., Paul Goldstein, 1 Copyright $\$ 1.2$, at 1:5 (Little, Brown and Co., $2 \mathrm{~d}$ ed. 1996); Landes \& Posner, supra note 106, at 328. 
then the first prynter, and then the first prynter shall never vtter [sell] his bookes.

Witl only sliglit modification to the Stationers' Company's language, substituting numerous private individuals for the "other" competing printer, the underlying public interest justification for protection remains fundamentally unchanged. If numerous individuals who would otlierwise purcliase an autliorized copy of the work are able to make their own unauthorized copy, then the copyright owner will liave little incentive to create and disseminate her works. As a result, protection against the risk of widespread private copying is necessary today, as protection against inore traditional infringement was in the past, to ensure the public an adequate supply of creative works.

Copyright today goes much further than the public interest requires, lowever. Although unauthorized copying can reduce the revenue for all creative works, it imphicates the public interest only in tloose specific cases in which the reduction goes so far as to render a given work unprofitable. For such marginal works, copyright protection serves the public interest directly by improving the profitability picture for sucl marginal works and thereby helping to ensure their creation. Unlike patent law, however, copyright law makes no attempt to limit its protection to those works that would not have been created but for the inducement of a copyright. ${ }^{191}$ To the contrary, copyright law today goes out of its way to maximize revenue for the most popular works, while doing very little to encourage the production of marginal works.

This misplaced emphasis on maximizing revenue for the nonmarginal work developed over the course of the twentieth century

14) The Arguments of the Patentees in Favour of Privileges for Books (May 4, 1586), in 2 A Transcript of the Registers of the Company of Stationers of London, 1554 1640 A.D.. at 805 (Edward Arber ed., 1875) (alteration in original) [hereinafter Arguments of the Patentees]; see also Int'l News Serv, v. Associated Press, 248 U.S. 215,241 (1918) ("Indeed, it is one of the most obvious results of defendant's theory that, by permitting indiscriminate publication by anybody and everybody for purposes of profit in competition with the news-gatlierer, it would render publication profitless, or so little profitable as in effect to cut off the service by rendering the cost prohibitive in comparison with the return.").

${ }^{19 !}$ For the patent law approach, see Gralıam v. John Deere Co., 383 U.S. 1, 11 (1966) (describing the limitation on patents to "those inventions which would not be disclosed or devised but for the inducement of a patent"). 
as the constant clamoring of copyright's propertied class drew copyright steadily away from its original public interest focus. ${ }^{192}$ Where copyright initially sought to protect a copyright owner agamst the copying competitor im order to provide the owner with a fair opportunity to recover the costs of her work, today it increasmgly seeks to protect a copyright owner against the loss of any opportunity to license her work in order to permit her to capture fully the work's associated market value. ${ }^{193}$ This evolution has led to a substantial expansion in the length and scope of copyright protection and has vastly increased the revenue associated with the most popular works. But it has done very little to encourage directly the production of marginal works. Almost by definition, a marginal work is worth only a little more than it costs. The switch to a value-based protection scheme therefore generates little additional revenue for the marginal work. In contrast, because nonmarginal works can command a market value considerably more than their cost, the switch has substantially mcreased the revenue for non-marginal works.

Copyright clearly serves the public interest when it protects a work that would not otherwise have been created. Such protection may generate additional revenue for the copyright owner, but it also offers the public a work that it would not otherwise have received. For such marginal works, protection primarily serves the public interest, and the private benefit of increased revenue to the copyright owner is merely incidental. But when protection provides

${ }^{192}$ See Jessica Litman, Copyright Legislation and Technological Change, 68 Or. L. Rev. 275, 278-82 (1989) (tracing the development of copyright law as a response to interested parties); Stewart E. Sterk, Rhetoric and Reality in Copyright Law, 94 Mich. L. Rev. 1197, 1198 (1996) ("[T] he nation's elite, including its lawmakers, has a stake in believing and acting on copyright rhetoric. The elite's investment in the status quo reinforces the power of the interest groups who have fueled copyright expansion.").

${ }^{193}$ See, e.g., Benny v. Loew's Inc., 239 F.2d 532, 534 (9th Cir. 1956) (discussing movie studio's proposition that copyright extends "to any lawful use of their property, whereby they may get a profit out of it"), aff'd sub nom. Columbia Broad. Sys. v. Loew's Inc., 356 U.S. 43 (1958); see also UMG Recordings v. MP3.com, 92 F. Supp. $2 d$ 349, 352 (S.D.N.Y. 2000) ("Any allegedly positive impact of defendant's activities on plaintiffs' prior market im no way frees defendant to usurp a further market that directly derives from reproduction of the plaintiffs' copyrighted works. This would be so even if the copyrightholder had not yet entered the new market in issue....") (citation omitted); Lunney, supra note 120, at 554-71 (tracing the evolution of copyright from a system intended to offer copyright owners a cost-based return to one offering a value-based return). 
an incentive far in excess of that necessary to ensure a work's creation, the public interest justification is far less clear. The public interest in such protection is not linked to the creation of the work itself, as it is with marginal works. By definition, sucl non-marginal works would have been created even without (or with far narrower) copyright protection. As a result, those aspects of copyright protection that generate excess incentives merely enrich lucky copyright owners without concomitant public benefit.

A strict reading of the DMCA which tightly restricts access to decryption technology will make this problem of excess incentives even worse. The strong encryption that would result from a strict reading of the DMCA would enable the copyright industry to price discriminate between their various customers more precisely than they are currently able. ${ }^{194}$ Strong encryption will therefore increase the revenue associated with producing any given digital work. This additional revenue may prove sufficient to ensure the profitability of a few additional works. Yet because such marginal works have a market value only slightly in excess of their costs, the predominant effect from strong encryption is to increase, perhaps substantially, the revenue associated with the most popular works.

On its face, a copyright statute that provides for excess incentives appears to violate the Constitution's pubhic interest limitation because excess incentives benefit copyright owners without offering the public anything in return. Over the years, however, those who support broad copyright protection have developed two justifications and an excuse for bringing excess incentives within Congress's constitutional authority. First, proponents of broad protection have insisted that excess incentives serve the public interest because they will be reinvested, at least in part, in the creation of

${ }^{1 *}$ See Julie E. Cohen, Copyright and the Perfect Curve, 53 Vand. L. Rev. 1799, 1801-08 (2000) (describing a model of copyright price discrimination); William W. Fisher III, Property and Contract on the Internet, 73 Chi.-Kent L. Rev. 1203, 1234-40 (1998) (same); Michael J. Meurer, Price Discrimination, Personal Use and Piracy: Copyright Protection of Digital Works, 45 Buff. L. Rev. 845, 876 (1997) ("Digital technology will encourage more price discrimination and greater profits to copyright holders regardless of the direction of copyright law in the digital world."); Glynn S. Lunney, Jr.. Comment. Atari Games v. Nimtendo: Does a Closed System Violate the Antitrust Laws?, 5 High Tech. L.J. 29, 41-46, 73 (1990) (arguing that Nintendo's use of a lockout chip may result in price discrimination). 
additional works. ${ }^{195}$ As a result, excess incentives not only enrich those who have created the most popular works but also lead to the creation of additional works. Excess incentives, proponents therefore insist, are consistent with the Constitution's public interest mandate.

This "trickle-down" vision of copyright is flawed. There are two types of works that might arguably benefit from such trickle-down reinvestinent. The first category consists of those works that are expected to prove profitable as a result of copyright protection. Although these marginal works lie near the heart of copyright's public interest justification, they cannot justify excess incentives. Because copyright has made this class of works profitable, they should not have to rely on trickle-down reinvestment to obtain the necessary financial backing. So long as they were expected to prove profitable at the outset, these works should be able to fend for themselves in the marketplace even if some prove unprofitable in the end. They would be created even in the absence of trickledown reinvestment. As a result, proponents of broad copyright cannot plausibly clami that these works are the result of excess incentives, even if some copyright owners routinely remvest a portion of their excess profits in such works.

A more plausible public interest rationale for excess incentives exists for a second category of works: those works that are expected to remain unprofitable even with today's broad copyright protection. Because these works are expected to lose money, they cannot be expected to attract the necessary financial backing in the market on their own. Production of these works may therefore depend on trickle-down reinvestment to go forward, and proponents of broad copyright can more plausibly assert that these works

${ }^{195}$ This argument also originated with the Stationers' Company. In a 1586 petition to the Star Chamber, the Stationers' Company asserted:

Also priviledges, are occasion, that many bookes are nowe prynted, which are more beneficial to the common welth, then proffitable to the prynter, for the Patentee beinge benefeted otherwise by Bookes of profitable sale is content to bestowe parte of his gayne in other bokes, which are within the compas of his patent, verie beneficiall for the common welth, and yet suche whereby the printer shall scarse reape the Tenth parte of his charge: which Bookes wolde never be prynted if privileges were revoked.

Arguinents of the Patentees, supra note 190, at 805. 
would not have been created but for the excess incentives available to other, more popular works.

Although this second category provides some plausible public interest justification for excess incentives, the possibility of trickledown reinvestment in this second category of works is not sufficient to bring excess imcentives within Congress's constitutional authority. The difficulty with trickle-down reinvestment for this category of works is the absence of any clear reason why a rational copyright owner would reinvest her excess incentives in an endeavor expected to lose money. A copyright owner may be in the business of producing copyrighted works and actively look for investment opportunities in that field first. But as actual behavior tends to prove, once the apparently profitable opportunities are gone, copyright owners will devote their resources elsewhere, whether on lavish lifestyles, restaurant chains, or large aircraft. ${ }^{196}$ Whatever reinvestment in otherwise unprofitable works inay occur, whether driven by a sense of charitable obligation, egoinduced blindness, or a simple mistake in estimating popular tastes, it is likely to prove too trivial to justify the degree of excess incentives that copyright provides today. Recall that even a protection scheme that focused exclusively on maximizing revenues for the copyright industry would have some mcidental tendency to increase the number of creative works available. ${ }^{197}$ Yet, the Constitution requires something inore than an incidental tendency to advance the public interest. It requires that protection serve the public interest primarily. By any rational measure, the possibility that some copyright owners may choose to reinvest a portion of their excess revenues in additional works does not convert the pri-

1\% Among the many copyright-financed extravagances that might be mentioned are the homes of Shania Twain and Bill Gates. See Matthew Wright, Twain's World: Shania's Pounds 10M Swiss Retreat, The Mirror (London), Feb. 10, 2000, at 19 ("Shania lives a hermit-like existence with producer husband Mutt Lange, im this spectacular pounds 10 million home on the banks of Lake Geneva."); Chris Solomon, 'Fatigue' in Medina over huge mansions: $\$ 500,000$ fine tied to length of project, The Seattle Tines. Mar. 17, 2001, at B1 ("This, after all, is the home of Microsoft founder Bill Gates and his $\$ 109$ million manse, with its 30-car garage and chattering manmade salmon stream."). Restaurants have also proven a popular investment for the wealth copyright can generate. James Aufenast, Five-Star Dining, Actors Used to Wait Tables Before They Were Famous; Now, When They Make It Big, They Buy the Restaurants. The Independent (London), Mar. 18, 2001, at 8-9.

in See supra text accompanying note 191 . 
marily private benefit of excess incentives into a primarily public benefit. Otherwise, the Stationers' Company could have retained its guild monopoly and proven that it was advancing "the Encouragement of learning" by occasionally donating a small fraction of its monopoly profits to schools. ${ }^{198}$

The second justification offered for excess incentives is the uncertainty often associated with the production of creative works. No one is quite sure which works will prove successful, and proponents of broader protection have suggested that this uncertainty can justify excess incentives for two reasons. First, proponents insist that absent the availability of excess incentives, the risk and uncertainty associated with creative works will discourage investinent in such works. ${ }^{199}$ In evaluating this argument, it is necessary to ensure that real risk is involved, rather than, for example, Hollywood accounting techniques which manage to show a loss even on the most popular works. ${ }^{200}$ Similarly, the analysis must discount those apparent losses that result from over-estimation of expected inonopoly profit. When a film is made or an album cut, the parties sit down, estimate the likely monopoly profit, and then divide the expected monopoly profit among those involved, with actors, directors, artists, and producers all receiving a salary or royalty advance reflecting their share of the expected monopoly profits. ${ }^{201}$

${ }^{198}$ See Amold Plant, The New Commerce in Ideas and Intellectual Property 15 (1953) ("A special case for a inonopoly for publishers cannot rest on the general proposition that if business men are enabled to make monopoly profits, some of them will be devoted to good works.").

${ }^{199}$ Goldstein, supra note 179 , at 83 (Without broad copyright protection, "[t]he availability of risk capital would decline, as would the willingness of publishers to try untried authors in the marketplace."); David Ladd, The Harm of the Concept of Harm in Copyright: The Thirteenth Donald C. Brace Memorial Lecture, $30 \mathrm{~J}$. Copyright Soc'y 421, 431 (1983) ("By limiting potential rewards in the copyright market ... the entrepreneurial calculus which precedes risk-taking in authorship and publishing is shifted in the direction of not takmg a chance, i.e., not writing or publishing a 'risky' work, whether ideologically or economically risky.").

${ }^{200}$ The legal attack on Hollywood's accounting methods began in Buchwald v. Paramount Pictures Corp., No. C-706083, 1990 Cal. App. LEXIS 634, at *44 (Cal. App. Dep't Super. Ct. Jan. 31, 1990); see also Tim Carvell, Lights! Camera! Lawsuit!, Fortune, Oct. 11, 1999, at 189, 192 (recounting how, following the Buchwald case "'Hollywood accounting' became a synonym for fraud").

${ }^{201}$ See generally Lunney, supra note 120, at $556 \mathrm{n} .282$ (discussing this phenomenon in the context of book publishing); Ejan Mackaay, Legal Hybrids: Beyond Property and Monopoly?, 94 Colum. L. Rev. 2630, 2635 (1994) ("[T]lie amount an investor 
If the monopoly profits fail to reach the expected level, revenues from the work may fail to cover the ex ante division of expected profits and generate the appearance of a loss. ${ }^{202}$ Such cases, however, do not reflect a true loss or a real risk any more than the apparent losses generated by artificial accounting techniques. If copyright expands to increase the revenue for such apparently marginal works, the expected monopoly profits associated with these works will increase. Consequently, the ex ante division of those expected profits will increase, and so the works will prove no more profitable after the expansion than they did before.

Even actual risk cannot justify an increase in protection without more. Risk is a real cost and should not be subsidized merely to encourage risk-taking. If two activities have otherwise identical costs, revenue, and expected benefit, but one has a higher level of associated risk, ${ }^{203}$ then the less risky activity generates a higher net social value. Facing a choice between these two activities, most individuals, being risk-averse, will and should choose the less risky activity. Moreover, subsidizing risk-taking activity merely because it is risk-taking leads to a vicious cycle. If only one in three works are profitable, and assuming that a one-im-three risk level justifies an increase in protection, imcreased protection will generate increased revenue for all three works. As a result, a fourth work that was previously too risky will now become a risk worth taking, and suddenly the success rate falls to one profitable work in four. ${ }^{204} \mathrm{But}$ if a one-in-three risk level justifies some increase in protection, surely a one-in-four risk level must justify somewhat more. Expanding protection again, because the activity is now riskier, means success rates will fall again, perhaps to one profitable work in five.

would be willing to sink into a particular project should depend upon his assessment of the chances of success and the expected revenues in case of success.").

$2 \mathrm{~m}$ Indeed, an economic doctrine known as the winner's curse suggests that such over-payment of expected monopoly profits will prove common. Alvin E. Roth, Introduction to Experimental Economics, in The Handbook of Experimental Economics 1, 60-65 (John H. Kagel \& Alvin E. Roth eds., 1995); see also E.C. Capen et al., Competitive Bidding in High-Risk Situations, 23 J. Petroleum Tech. 641 (1971) (finding evidence of rates of return on offshore oil-and-gas leases that were systematically below market rates).

${ }^{201}$ At the simplest level, greater risk refers to a wider variation in the possible outcomes for a given mean outcome.

Given that risk-taking is being subsidized, it slıould not be surprising to see the risk level increase. 
Such a vicious cycle arises not only in theory, but is reflected in the steadily falling success rates for the copyright industry over the last two hundred years. ${ }^{205}$

Risk and uncertainty, as discouragement, can justify some degree of protection only to the extent that they represent a cost that a first producer bears, but second-comers avoid, because they follow the path blazed by a proven work. Yet, even this legitimate risk-based argument has weaknesses. The cost advantage for imitators from imcurring less risk will lead to a sub-optimal production of creative works only to the extent that the risk savings available from imitating works of authorship is disproportionately large compared to that available from imitating one of the wide range of creative products that copyright leaves unprotected. ${ }^{206}$ Given the low success rate for new products generally, ${ }^{207}$ there is hittle reason to beheve that the imitator of a copyrighted work obtains a disproportionate risk savings as compared to imitators generally. In addition, even at its narrowest, copyright in the United States has

${ }^{205}$ Compare Petition to the High Court of Parliament (April 1643), in 1 Transcript of the Registers, supra note 190, at I.587 (asserting, in a 1643 petition on behalf of the Stationers' Company, that "scarce one book of three sells well, or proves gainfull to the publisher"), and Arnold Plant, The Economic Aspects of Copyright in Books, 1 Economica (n.s.) 167, 183 (1934) (citing an 1878 article for the proposition that "[f]our books out of five which are published do not pay their expenses"), with Digital Audio Recording: Hearing on H.R. 4567 Before the Subcomm. on Commerce, Consumer Prot., and Competitiveness of the House Comm. on Energy and Commerce, 102d Cong. 88 (1992) (statement of Jason S. Berman, President, Recording Industry Association of America) ("[O]nly 15 percent of all recordings released recoup their costs...."), and Home Recording of Copyrighted Works: Hearings Before the Subcomm. on Courts, Civil Liberties, and the Admin. of Justice of the House Comm. on the Judiciary, 97th Cong. 29 (1982) [hereinafter Home Recording Hearings] ("Six out of ten films never recoup their total investment, period."), and id. at 547 (statement of Jerry Moss, chairman of A\&M Records) ("Eighty-four percent of all [sound recording] industry releases fail to recover their costs. Six percent of classical records make it into the black.").

${ }^{205}$ See Lunney, supra note 182 , at $446-48$ (noting that free riding leads to inefficiency only where free riding in one sector of the economy is relatively greater than free riding in other sectors).

${ }^{2 m}$ E.g., Mitzi M. Montoya-Weiss and Roger Calantone, Determinants of New Product Performance: A Review and Meta-Analysis, $11 \mathrm{~J}$. Prod. Innovation Mgmt. 397, 401-02 (1994) (summarizing studies of new product introductions that report success rates from thirty-eight to sixty-eight percent); Robert Prentice, Vaporware: Imaginary High-Tech Products and Real Antitrust Liability in a Post-Chicago World, 57 Ohio St. L.J. 1163, 1171 (1996) (noting that eighty percent of new products in the high-tech field fail). 
always prohibited exact and near-exact duplications. Because exact copying is forbidden, the question is whether approximate copying provides any real guarantee of success. The inability of imitators to duplicate the success of television shows like Who Wants to $\mathrm{Be} a$ Millionaire? and Friends ${ }^{208}$ suggests that imitating approximately does not significantly reduce the risk and uncertainty associated with a follow-on work. In any event, this risk-savings concern implicates the public welfare only at the margins, for those original works rendered unprofitable by a disproportionate risk savings available to imitators. To advance copyright's legitimate end, regulators might constitutionally solve this concern by providing slightly broader protection for marginal works in order to reduce the risk savings available to imitators. But it is hard to see any rational relationship between awarding extremely high returns to the most popular works and solving whatever problem risk savings may present for marginal works.

Uncertainty coinbined witl extremely high returns for the inost popular works can also serve to encourage the creation of additional works through a type of lottery effect. Because no one is quite sure whose work will become the next Gone with the Wind, offering extremely high returns for the most popular works represents, in a sense, a lottery. ${ }^{209}$ All that an imdividual must do to enter is author a creative work. Studies have shown that a small chance for extreme wealth will attract disproportionate resources. ${ }^{210} \mathrm{Peo}-$

Raymond L. Fischer, Quiz Show Mania: Daja [sic] Vu With a Vengeance, USA Today, Sept. 1, 2000, at 66, 68 (noting failure of Greed, Twenty-One, and Winning Lines launched respectively by Fox, NBC, and CBS in an attempt to duplicate Millionaire's appeal); Diane Holloway, TV's midseason scramble: Networks conjure up nearly 20 new series after fall debuts yield plenty of duds, Austin-American Statesman, Jan. 6, 1996, at E1 ("So, what went wrong? The schedule was too crowded and too full of clones. Whoever said you can't have too many friends wasn't thinking of fall's television season, when at least a half-dozen newcomers copied the concept and attractive, 20-something casting of NBC's 'Friends.' But they forgot to copy the clever writing style, so viewers tumed away.").

${ }^{2}$ M Goldstein, supra note 179 , at 83 ("A robust copyright, by contrast, will mix the hope of high return on some works with risk of loss on others, giving publishers, if not quite a lottery, then at least a portfolio that will promote imvestment and sustain a wider variety of authorship than could command support under any other legal system.").

2:" D. Michael Risinger et al, Brave New "Post-Daubert" World-A Reply to Professor Moenssens, 29 Seton Hall L. Rev. 405, 425 (1998) (noting "the well-known tendency for a majority of people to become risk-preferring in circumstances of 
ple will spend resources for a chance of winning even if their expenditure significantly exceeds their expected return, as shown by the sales of lottery tickets that offer an expected return of only fifty to seventy-five cents on the dollar. ${ }^{211}$ Providing extremely high profits for the most popular works may generate a similar lottery effect, attracting resources to works whose cost exceeds their expected revenue. As a result, the existence of excess incentives for the most popular works may lead to the production of additional marginal works, or so proponents of broader protection might claim.

While this argument may appear valid under the traditional incentives-based analysis of copyright, it is flawed as well. As I have shown elsewhere, the true cost from too much copyright protection is the same as the cost from too little protection. ${ }^{212}$ As the Stationers' Company long ago articulated, the cost to society from too little protection is that there will be too few works. More precisely, scarce resources, in the form of creativity, will be devoted elsewhere even though society would have preferred they be invested in additional works of authorship. Although the traditional incentives-based analysis describes the costs of overbroad protection in

potential high rewards and low costs, regardless of rational odds (sometimes referred to as the lottery effect)"); see also Daniel Kahneman \& Amos Tversky, Prospect Theory: Analysis of Decision Under Risk, 47 Econometrica 263 (1979) (discussing phenomena which violate tenets of expected decision-making, including decisions about gambling with a low probability of success coupled with a high return); Amos Tversky \& Damiel Kahneman, Advances in Prospect Theory: Cumulative Representation of Uncertainty, 5 J. Risk \& Uncertainty 297 (1992) (similar).

${ }^{211}$ E.g., Charles M. Yablon, A Dangerous Supplement? Longshot Claims and Private Securities Litigation, 94 Nw. U. L. Rev. 567, 588 n.72 (2000) ("The popularity of lotteries obviously reflects the fact that this [the general assumption of riskaversion] is not true for very small chances of very big gaims, where many people seem to be risk-preferring.").

${ }^{212}$ See Lunney, supra note 120, at 492, 600; see also Staff of Subcomm. on Patents, Trademarks, \& Copyrights, Senate Comm. on the Judiciary, 85th Cong., An Economic Review of the Patent System 45-46 (Comm. Print 1958) (Study No. 15, prepared by Fritz Machlup) (making a similar argument about patents); Benjamin Kaplan, An Unhurried View of Copyright 75 (1967) ("Magnify the headstart and you may conceivably run the risk of attracting too much of the nation's energy into the copyright-protected sectors of the economy."); Robert M. Hurt \& Robert M. Schuchman, The Economic Rationale of Copyright, 56 Am. Econ. Rev. 421, 425,430 (1966) (suggesting that the gains provided by additional works of authorship must be offset by losses in other areas); Plant, supra note 205, at 170 ("The output which monopoly alone can evoke is not normally regarded as preferable to the alternative products which free competition would allow to emerge."). 
terms of lost access, the cost from overbroad copyright is the same type of misallocation. Individuals will devote their creativity to additional works of authorship, even though society would have valued those resources more highly if they were invested elsewhere..$^{113}$ When there is a lottery effect which attracts additional resources into the production of additional works whose costs exceed their expected revenue, the very fact that cost exceeds expected revenue for these additional works establishes that the resources required were more highly valued elsewhere. Instead of remedying the misallocation of creativity from too little copyright protection, too much protection and the resulting excess incentives will re-create the same type of misallocation problem that copyright was supposed to solve. Rather than "promote the Progress of Science," excess incentives promote waste by attracting too much creativity into the production of works of authorship and leaving too little for other more valuable uses. Such an effect can scarcely be said to advance the public welfare.

The third argument for excess incentives is more in the nature of an excuse. Here, the argument is not that excess incentives are affirmatively desirable, but that they are inevitable. Both as a practical matter and to avoid the dangers of pohtical censorship, the argument goes, copyright will almost necessarily provide a uniform level of protection for all works. Given a uniform level of protection, every work but the truly marginal will earn revenue at least slightly more than its costs. Excess incentives are therefore an inevitable byproduct of copyright's attempt to ensure production of the works that would not have been created but for copyright. As a result, attempting to eliminate excess incentives altogether is both futile and unworkable. As David Ladd and others have suggested, nothing could be more dangerous to a vibrant and varied creative output than to recast copyright into the mold of a rate regulation statute requirmg copyright owners to submit evidence of their fixed and marginal costs and requiring courts to then tailor

212 Lunney* supra note 120 , at 492,600 . In an interesting early model, Professor Thompson demonstrated that in a perfect market, with perfect information and perfect competition, private production would lead to an oversupply of public goods. Earl A. Thompson, The Perfectly Competitive Production of Collective Goods, 50 Rev. Econ. \& Stat. 1 (1968); Earl A. Thompson, The Perfectly Competitive Production of Collective Goods: Reply, 51 Rev. Econ. \& Stat. 479 (1969). 
copyright protection to ensure a fair return on owners' investment. $^{214}$

Given the difficulties of more perfectly tailoring copyright's ends-means fit for each individual work, some degree of excess incentives is probably inevitable and unust necessarily fall within Congress's constitutional authority. But to cover the degree of excess incentives copyright systematically provides today, proponents must stretch this excuse further than it can constitutionally bear. Moreover, even assuming that this excuse justifies excess incentives in the context of traditional infringement, this excuse does not as readily apply to private copying. As discussed, to the extent that private copying increases with the popularity of a work, private copying may reduce the excess incentives associated with the most popular works, and yet not materially reduce the incentives necessary to ensure the creation of the marginal works. Private copying would not therefore threaten the public interest that the Constitution requires copyright to serve. Furthermore, to the extent that private copying achieves this reduction on its own, it would not require a judicial or legislative work-by-work determination of copyright's proper scope. Private copying may therefore improve copyright's ends-means fit without requiring elaborate and ultimately unworkable government supervision. Given this selfregulating character, the excuse traditionally used to justify excessive incentives would not apply. With the availability of private copying, excess incentives are no longer an inevitable side effect of ensuring adequate incentives for works at the margins, at least not to the degree they exist today. As a result, prohibiting private copying serves no purpose but to enrich copyright owners and therefore falls outside congressional authority under the Patent and Copyright Clause.

The self-regulating character of private copying stems from two network effects. ${ }^{215}$ The first arises when consumers make decisions

${ }^{214}$ Ladd, supra note 199, at 431-32 ("Every limitation on copyright is a kind of ratesetting. And however high-minded, every person who thus sets rates applies a valuejudgment: how much the author or publisher should receive. ... This control of idealaden copyrighted works is more wisely left with the people than vested in a government tribunal, a statutory license fee, or even a sincere judge searching a record for undefined harm.").

${ }^{215}$ A network effect refers to a situation where "the utility that a user derives from consumption of the good increases with the number of other agents consuming the 
as to which works they desire to copy privately. Because of this first effect, more individuals will seek to privately copy popular works. The second, complementary network effect arises from the likely availability of particular works for private copying. Because of this second effect, more popular works will more likely be available for private copying.

The first effect arises because the desirability of a work derives in part from the fact that others have experienced it as well. Although commentators and courts have readily accepted the notion of such network effects for computer programs, ${ }^{216}$ the effects are present for copyrighted works more generally. The estabhshed relationship between imcreased airplay and increased sales for musical works more generally ${ }^{217}$ reflects the fact that others' knowledge and expectations of a particular work can shape our desire for that work, even if there are other works that convey the same ideas just as well. ${ }^{218}$ Although the network effects of popularity are not likely to determine completely a work's market success or failure, they suggest that an important element in a work's success is whether the work develops an audience sufficiently large to offer

good." Michael L. Katz \& Carl Shapiro, Network Externalities, Competition, and Compatibility, 75 Am. Econ. Rev. 424, 424 (1985); see generally Mark A. Lemley \& David McGowan, Legal Implications of Network Economic Effects, 86 Cal. L. Rev. 479, 488-95 (1998) (distinguishing between actual networks, virtual networks, and simple positive feedback phenomena).

${ }_{216}$ E.g., Lotus Dev. Corp. v. Borland Int'l, Inc., 49 F.3d 807, 818 (1st Cir. 1995) (refusing to protect the command structure of Lotus 1-2-3, in part, because of the network or lock-in effect generated once users have learned the command structure), aff d by an equally divided Court, 516 U.S. 233 (1996); Sega Enter. v. Accolade, Inc., 977 F.2d 1510, 1520 (9th Cir. 1992) (copying of another's copyrighted computer program constitutes fair use where copying is necessary to acquire information that will ensure compatability); Peter S. Menell, An Analysis of the Scope of Copyright Protection for Application Programs, 41 Stan. L. Rev. 1045, 1079-82 (1989) (arguing for narrow protection for computer programs as a result of network externalities associated with their use).

${ }^{217}$ Goldstein, supra note 10, at 74 (noting that falling sales of records and sheet music when radio stations ceased airplay of ASCAP music on January 1, 1941 "establish[ed] the empirical truth of the broadcasters' claim that radio broadcasts in fact boosted music sales"); Lunney, supra note 120, at $629 \mathrm{n.473}$ (noting recurrent payola scandals in radio broadcasting where record labels paid radio stations to play their albums in order to boost record sales).

${ }_{21 \times}$ See Glynn S. Lunney, Jr., Lotus v. Borland: Copyright and Computer Programs, 70 Tul. L. Rev. 2397, 2414-17 (1996) (exploring switching costs and network effects associated with popular entertaining works and comparing them to those involved with computer programs). 
its members an opportunity to share their enjoyment of the work with each other. Once a work's audience reaches that size, the resulting shared enjoyment reinforces the work's desirability and enhances the work's appeal to potential new audience menibers.

Because of these network effects, we should expect that a work either beconies sufficiently popular to generate a popularity network and then becomes even more popular, or it does not and thus never will. The sharp disparity between the revenue and audience size for popular works and those for less popular works starkly reveals this popularity divide. For exanıple, an examination of domestic box office receipts as reported in Variety's annual summary of the top 250 films of the past year reveals that the twentyfifth most popular film had a domestic box office more than 68.8 and 51.2 times that of the twenty-fifth least popular film in the years 1999 and 2000, respectively. ${ }^{219}$ By way of contrast, a similar examination of incoine mequality generally in the United States reveals that for the years 1995 through 1997 the ratio of annual (individual) income for a man at the minetieth centile and a man at the tenth centile ranged from 5.61 to 6.39 and for annual household income ranged from 2.70 to $2.88 .^{220}$ This comparison suggests that income disparities for creative works are far more substantial than income disparities in the market generally. Moreover, the top ten percent of the films received $48.2 \%$ and $43.9 \%$ of total domestic box office receipts in 1999 and 2000, respectively. ${ }^{211}$ In contrast, the bottom ten percent of the films received only $0.32 \%$ and $0.36 \%$ of the total doinestic box office in 1999 and 2000, respectively.

${ }^{219}$ Anthony D'Alessandro, Top 250 of 2000, Variety, Jan. 8-14, 2001, at 20 [hereinafter 2000 Movie Gross]; Anthony D'Alessandro, The Top 250 of 1999, Variety, Jan. 10-16, 2000, at 20 [hereinafter 1999 Movie Gross].

${ }^{220}$ See Finis Welch, In Defense of Inequality, 89 AEA Papers \& Proceedings 1, 5 (1999).

221 The top twenty-five films of 1999 grossed $\$ 3,565,175,000$. See 1999 Movie Gross, supra note 219 . Domestic box office for 1999 was $\$ 7.4$ billion. Id. The top twenty-five films of 2000 grossed $\$ 3,267,392,000$. See 2000 Movie Gross, supra note 219. Domestic box office for 2000 was $\$ 7.45$ billion. See Dade Hayes, Late Rally Lifts Wilted Wickets, Variety, Jan. 8-14, 2001, at 9 (reporting domestic box office of $\$ 7.45$ billion); 1999 Movie Gross, supra note 219, at 20 (reporting domestic box office of $\$ 7.4$ billion).

22 The bottom twenty-five films of 1999 grossed $\$ 23,832,000$. See 1999 Movie Gross, supra note 219 . The bottom twenty-five films of 2000 grossed $\$ 26,665,000$. See 2000 Movie Gross, supra note 219. 
On its own, this sharp disparity in revenue suggests that private copying would necessarily reduce revenue far more for popular works than for less popular works even if private copying were directly proportional to traditional popularity ${ }^{223}$ Rather than directly proportional, however, private copying is likely to increase with a work's popularity. Focusing on private copying between individuals in the absence of some central repository, the ability to copy privately depends entirely on an individual's ability to find anotler who is willing to make the file available for copying. This need to find another from whom to copy generates a second, complementary network effect. Because of the first, consumption-based network effect, more people are likely to have copies of a popular work. As a result, other factors being equal, finding someone who has and is willing to share is likely to be far easier with a popular work than with a less popular work. Knowing this, individuals are far more likely to look for opportumities to copy popular works privately.

In a recent study of Gnutella usage, for example, Eytan Adar and Bernardo A. Huberman found that the vast majority of Gnutella queries (that is, file requests) are concentrated on a relatively few topics. ${ }^{24}$ Based upon a recorded set of 202,509 Gnutella queries, they report that:

The top 1 percent of those queries accounted for $37 \%$ of the total queries on the Gnutella network. The top 25 percent account for over $75 \%$ of the total queries. In reality these values are even higher due to the equivalence of queries ("britney spears" vs. "spears britney"). ${ }^{25}$

${ }^{223}$ In distributing the money collected through private copying levies, many collecting societies in Europe simply assume that private copying is proportional to more traditional measures of popularity. See Kreile, supra note 136, at 466 (describing GEMA's method of distributing private copying levies as an "additional percentage" to royalty payments for more traditional distribution methods, such as sales of prerecorded cassettes and radio airplay); Weimann, supra note 136, at 167 ("Indicators as to the frequency of home tapings of a work may be in case of musical works the number of public broadcasts, or in the case of a record, its sales...."); see also Deloitte \& Touche, supra note 135, at 58-59 (describing use of general surveys to allocate private copying levies). For an analysis of how this approach would distribute a levy on VCRs and blank videocassettes, see infra note 322.

is Adar \& Huberman, supra note 186.

Ixs Id. 
As these data suggest, popularity itself, because of its associated network effects, leads individuals looking to engage in private copying both to seek and to find popular works far more often than less popular works. Thus private copying will affect popular works disproportionately.

As a result, private copying may reduce revenue significantly for the inore popular works, yet leave largely untouched the incentive to create less popular, marginal works. Given that result, private copying is unlikely to reduce creative output. It may simply reduce the excessive incentive copyright otherwise provides for the most popular works. Moreover, by enabling consumers to recapture a portion of the excess incentives associated with more popular works, private copying leaves consumers with a hittle extra money im their pockets, some of which consumers are likely to reinvest in marginal works. Although exactly how much consumers will choose to reinvest in additional works of authorship, as compared to soine other use, is unclear, ${ }^{226}$ there is every reason to believe that consumers will reinvest at least some. Given that awarding these excessive incentives to copyright owners would lead to additional works through trickle-down reinvestment only through mistake or charity, ${ }^{27}$ consumers are, almost necessarily, likely to reinvest as much, if not more, of these recaptured resources in marginal works as would the owners of the most valuable copyrights. In addition, allowing consumers to decide how these excess imcentives are reinvested gives consumers a louder voice im determining which marginal works are financed and produced.

If private copying does not reduce the incentives for creating additional works at the margins, but merely reduces the excess incentives available for the non-1narginal works, then that fact alone

${ }^{226}$ For example, the plaintiffs' own expert in $A \& M$ Records v. Napster, Inc, 239 F.3d 1004, 1010-11 (9th Cir. 2001), found that although album sales had decreased around some college campuses, sales had increased nationally. See Report of Michael Fine 1, at http://www.riaa.com/pdf/fine.pdf (June 10, 2000). The plaintiffs' expert, perhaps not surprisingly, concluded from this that high levels of Napster usage on college campuses was reducing sales at nearby record stores. Id. at 1-2. Yet, the continued growth in national sales may also suggest that college students are spending on music the money they saved by downloading at college after they return home. Id. at 2 (noting that "[s]ince the first quarter of 1997, total national album sales have grown by $18 \% ")$.

${ }^{27}$ See supra text accompanying notes 201-04. 
is sufficient to place private copying beyond Congress's reach under the Patent and Copyright Clause. The argument can go considerably farther than suggesting that reducing excess incentives is merely unlikely to harm the production of creative works, however. Reducing excess incentives is likely to prove affirmatively desirable because excess incentives distort the authorship process and may perversely discourage the labors of the most popular authors. The fundamental assumption behind the systematic expansion of copyright over the last two hundred years is that inore incentives mean more and better works. ${ }^{228}$ Yet, this fundamental assumption has gone largely unexamined and untested. In part, this assumption goes unexamined because it has soine obvious, if superficial, truth. In part, it goes unexamined because any atteinpt to examine more deeply the link between money and creativity quickly becoines mired in uncertainty. Despite these difficulties, the fundamental nature of this assumption warrants at least some attempt to evaluate the supposed link between inoney and creativity. One way is to ask a simple question: Is it likely that Shakespeare would have written inore works, or works of better quality, if he were paid unimaginable suins of money following his first popular success? For this is what the expansive copyright system does today. It pays almost unimaginable sums of inoney to authors for a popular hit, and then hopes that the payment will lead to more and better works. ${ }^{29}$

Asking this question suggests two concerns that undercut the assumption that more protection and higher returns for the inost popular works will lead to inore and better works. At the outset of this discussion, let me offer a caveat. Every author is different; every creative effort is different. Generalizations are usually hazardous. In that light, the following two considerations are offered with some hesitancy and a strong cautionary note. They are offered nevertheless, with the hope of casting soine hight onto copyright's fundamental assumption.

${ }_{22 x}$ See, e.g., 144 Cong. Rec. H7092 (Aug. 4, 1998) (statement of Rep. Frank) ("If we do not see that authors and composers and singers and musicians and other creative people are rewarded for their work, not only is that unfair, to many of us, but the amount of work we get will dimimish.").

${ }_{224}$ In my classes, I sometimes refer to this hope as the "Shakespeare Hypothesis." 
First, broadening protection and increasing returns for the most popular works may shift authorship effort away from great works toward popular works. Broad copyright may give us Madonna instead of Mozart, Sheldon instead of Shakespeare, and the Backstreet Boys instead of Bach. This is not to suggest that great works caumot be popular nor is it to impose soine ehtist distaste for popular works. ${ }^{230}$ There may well be considerable overlap between great and popular works. Yet, there is also a considerable difference between them. Popular works offer currency; great works endure. Popular works offer superficial enjoyment; great works offer meaning. Most importantly for copyright law, popular works have large sales; great works may not. This is not to say that popular works are more valuable than great works, even in an economic sense. But popular works tend to have large audiences whose individual reservation prices are tightly clustered around the typical market price for such works. That combination maximizes the private return available for any given social value and therefore leads copyright to reward popularity disproportionately. ${ }^{231}$

By offering substantial, and in some cases almost umimaginable, returns for popular works, copyright introduces a certain tension into the creative process: Should an author strive for a great work or a popular one? While the obvious ideal would be to author a work that is both, an author may be capable of only one or the other at any given time. Given that copyright operates generally on the principle that monetary rewards can influence behavior, offering higher returns for popular works may influence these authors to pursue popularity instead of greatness.

In addition, popular works, almost by definition, must appeal to a wider audience. Seeking the common denominator among a wider audience leads almost inevitably to a lower common de-

${ }^{230}$ Justice Holmes' admomition in Bleistein v. Donaldson Lithographing Co., 188 U.S. 239 (1903), bears repeating here: "It would be a dangerous undertaking for persons trained only to the law to constitute themselves final judges of the worth of pictorial illustrations, outside of the narrowest and most obvious limits." Id. at 251.

231 John Kay, The Economics of Intellectual Property Rights, 13 Int'l Rev. L. \& Econ. 337, 348 (1993) ("[T]he intellectual property that is well protected is not intellectual property of great value or great creative merit, and the intellectual property that is of great originality and great creative merit is not at all well protected. The result is that quite disproportionate resources are attracted to producing these essentially second-rate, but fortuitously favored, activities."). 
nominator. As a result, striving for popularity may produce not a wonderful, cacophonous variety, but a dulling, repetitive sameness as works include over and over the same elements intended to cater to popular tastes. Rather than free authors to explore their own inspirations, as some commentators have suggested ${ }^{232}$ excess incentives may chain authors ever more tightly to the formula that first brought them popular success. This effect has been quite pronounced in the music industry, where musicians have coined the term "corporate rock" to identify those works that follow certain forms to ensure their popularity. ${ }^{233}$ Yet, the influence of money is pervasive in all of the copyright imdustries and is likely to reshape creative decisions in order to ensure a work's marketabihity at the expense perhaps of something more..$^{234}$

232 Goldstein, supra note 179 , at 83 ; Ladd, supra note 199 , at 431 ; Neil Weinstock Netanel. Copyright and a Democratic Civil Society, 106 Yale L.J. 283, 358-59 (1996). All three scholars argue that giving authors a hittle more protection than might strictly be required can create breathing space for authors to express themselves more freely. There is an inconsistency in their reasoning. To identify this inconsistency, we must first unpack what it would mean to give authors "a little more protection." Although not formally stated, this concept seems to entail broadening protection to ensure somewhat more revenue for any given work than is strictly necessary to ensure its creation. In other words, for any given level of popular and market success, we will create a system of protection that enables a work to earn somewhat more, rather than somewhat less. Restated in this way, it becomes clear that these commentators are suggesting we increase the rewards for popular success in order to free authors to pursue something other than popular success. The inconsistency arises because these commentators are necessarily assuming that monetary rewards influence behavior (thus, the need for a little extra protection to provide authors with a monetary cushion) and at the same time, assuming that authors will ignore the increased monetary rewards to pursue something else. This inconsistency does not preclude the possibility that some authors may find sudden wealth liberating, but given copyright's general assumption that additional incentives will shape people's efforts, increased rewards for achieving popularity would seem to promote increased authorship directed at achieving popularity.

${ }^{27}$ See generally Negativland, Fair Use: The Story of the Letter U and the Numeral 2. at 190 (1995) (arguing that music is now "a trans-national busimess, run not on artistic motivations but on the bottom lines drawn by lawyers and accountants").

${ }^{24}$ The pervasive importance and likely influence of money is seen inost readily in the uniform use of rankings based upon sales and viewership across the entertainment industries, including the New York Times' Bestseller's List, Billboard's album and single lists. gold and platinum albums based upon sales, and Variety's top films list. See also Negativland, supra note 233, at 154, 189-90 (noting pervasive infiuence of money within the music industry). Consider this recent interview in Newsweek:

[NEWSWEEK:] The world's obsessed with box office. It's depressing, isn't it?

ZWlCK [Producer of Traffic]: We've all been co-opted by the numbers. 
What is lost as a result of the distorting effect of excessive incentives is impossible to determine. If copyright's underlying assumption that people respond to inoney is accurate, however, ${ }^{235}$ then it seems clear that offering very high returns for the inost popular works almost certainly costs society some of the great works it desires. ${ }^{236}$ Private copying, by reducing the monetary returns available to the most popular works, can reduce the difference between the returns available for popularity and the returns available for greatness. Private copying can reduce the distorting effect that inordinate incentives for the most popular works can generate and can thereby restore the author's freedom to pursue her own creative vision.

Second, broadening protection and increasing the returns for the most popular works will likely decrease the productivity of our most popular authors. While copyright simplistically assunnes that more incentive means more productivity, this assumption is flawed. At some point, higher returns for a given author's work will likely reduce that author's creative output. ${ }^{237}$ Economists call this reversal in output the backward-bending labor supply function, and they

GRAZER [Producer of Dr. Seuss' How the Grinch Stole Christmas]: More than ever.

ZWICK: This notion of what the opening is, what the gross is ... All of us at this table came to our passion for movies based on a love of movies, none of which we could sit here and name the grosses of. The whole culture has ascribed ineaning to numbers. It began in the ' $80 \mathrm{~s}$ when we didn't know what baseball players made, we didn't know what CEOs were paid... And now we're all prey to it. There is a constant reaffirmation of its importance in all our lives. So much of our days, our talk, becomes consuned by it that we begin to beheve in it.

Jeff Giles \& David Ansen, Pass Me an Oscar, Newsweek, Feb. 5, 2001, at 56, 59 (ellipses in original).

${ }^{235}$ Certainly, there is good reason to expect that increasing returns can influence behavior. Richard B. Freeman, Demand for Education, in 1 Handbook of Labor Economics 357, 370 (Orley Ashenfelter \& Richard Layard eds., 1986) ("The investment model of the decision to pursue education has been studied extensively with generally favorable results for the key behavioral assumption: that individual decisions respond significantly to meet incentives."); Welch, supra note 220 , at 13 (tracing collective responses in the level of education individuals chose to obtain given changes in the education-based wage differential).

${ }^{236} \mathrm{Cf}$. Wendy J. Gordon, Norms of Communication and Coinmodiflcation, $144 \mathrm{U}$. Pa. L. Rev. 2321, 2337 (1996) ("If not all goods and values are commensurable with money, that suggests that imcreasing the ainount of money attached to a given behavior will not always generate a significant increase in the behavior.").

${ }^{237}$ Varian, supra note 148 , at 173. 
typically introduce it to their students by asking the students how many hours each would work for a given wage. Usually the answers suggest that, when wages are low, an increase in the wage will lead to additional time working as the offer of a higher wage makes additional work and the resulting additional incoune more attractive. As the wage continues to increase, students begin to realize that they can earn enough income to sustain the lifestyle they seek with fewer hours and also realize that a little leisure time to enjoy their earnings would be nice. Once that point is reached, mcreasing the wage tends to decrease the time worked. ${ }^{238}$

More formally, this backward-bending labor supply arises from two effects: a substitution effect and an income effect. ${ }^{239}$ Higher wages make work nıore attractive relative to leisure, leading an individual to substitute work for leisure (the "substitution effect"). Yet, higher wages also produce higher incounes that lead an individual to increase her demand for various goods imcluding additional leisure (the "income effect"). Once wages reach the point where the incoine effect begins to outweigh the substitution effect, any further wage increases will reduce the time spent working. ${ }^{240}$

The available empirical evidence uniformly indicates that, for the average individual, labor supply begins to fall with imcreasing wages at a wage well below the level that broad copyright protection offers popular authors today. In terms of comparison, only lottery winners experience sudden wealth in a way similar to that of suddenly popular authors today. Studies of lottery winners demonstrate that such large awards sharply reduce, on average, time worked. ${ }^{241}$ As Professor Gregory Mankiw has summarized:

\footnotetext{
${ }^{2 w}$ See, e.g., id. at 174.

${ }^{239}$ Id. at $174-75$.
}

24. Id.

${ }^{24}$ Guido W. Imbens et al., Estimating the Effects of Unearned Income on Labor Supply, Earnings, Savings, and Consumption: Evidence from a Survey of Lottery Players 2 (Nat'l Bureau of Econ. Research, Working Paper No. 7001, 1999), http://dsl.nber.org/papers/w7001.pdf ("We find that winning a modest prize $(\$ 15,000$ per year for twenty years) does not affect labor supply or earnings substantially... Winning a much larger prize $(\$ 80,000$ rather than $\$ 15,000$ per year) reduces labor supply as measured by hours, as well as participation in the labor force and social security earnings...."); H. Roy Kaplan, Lottery Winners and Work Commitment: A Behavioral Test of the American Work Ethic, $10 \mathrm{~J}$. Inst. for Socioecon. Stud. 82, 90 (1985) ("Generally, as the size of the winning increased, so too 
The results from studies of lottery winners are striking. Of those winners who win more than $\$ 50,000$, almost 25 percent quit working within a year, and another 9 percent reduce the number of hours they work. Of those winners who win more than $\$ 1$ million, almost 40 percent stop working. The income effect on labor supply of winning such a large prize is substantial. ${ }^{242}$

Although there are differences between lottery winmings and copyright royalties that caution against applying these precise changes in labor supply directly to the production of copyrighted works, ${ }^{243}$ these findings strongly suggest that the excess incentives available to authors today may not only distort the authorship process by encouraging the production of popular works at the expense of great works, they may reduce the supply of works from our most popular authors as well. ${ }^{244}$ Agam, private copying, by reducing the excess incentives available, can help redress the disincentive that excess incentives would otherwise create.

did the number of changes. Twenty-three percent of million dollar winners quit working. At the other end of the spectrum, none who won less than $\$ 50,000$ quit.") (italics omitted); see also Douglas Holtz-Eakin et al., The Carnegie Conjecture: Some Empirical Evidence, 108 Q.J. Econ. 413, 420 (1993) (examining effects of inheritance on labor supply and finding that "[a] consistent story appears to emerge: higher inheritances are associated with a greater propensity to exit the [labor] market").

${ }^{242}$ N. Gregory Mankiw, Principles of Microeconomics 483 (2d ed. 2001).

${ }^{243}$ The principal difference between the two is that lottery winnings represent unearned income that is unrelated to the individual's work. In contrast, authorship royalties are earned, though perhaps uncertain and sometimes unexpected, and certaimly related to the individual's work as an author.

${ }^{24}$ In the field of invention, corporations usually obtain assignments of patent rights from their einployees in advance. Although the particular employee responsible for a given imvention may receive soine increase in salary as a result of her particular profitable inventions, most of the excess incentive goes to the corporation and is redistributed annong a pool of researchers as a form of risk sharing. Such an approach would tend to avoid the reduction in labor supply that large awards to the particular inventor would otherwise create. Such an approach is inore difficult to apply in copyright both because works of authorship are too driven by individual talent (or name recognition) to sustain such an approach, and because the termination provisions in $\$ \$ 203$ and 304 preclude effective assignment of the entire copyright. 17 U.S.C.A. $\$ \S 203,304$ (2000). 


\section{B. Copyright's Capture: The Political Economy of Copyright and the Need for Civil Disobedience}

In addition to securing a better fit between copyright and the public interest, private copying can also serve as an important element of democratic self-governance in two senses. First, it provides an avenue for civil disobedience that enables otherwise disenfranchised consumers to express their dissatisfaction with copyright's present scope. Second, by allowing individuals to determine the proper level of protection for themselves, private copying can serve as a type of direct democracy that avoids the agency-cost pitfalls present when relying on a representative democratic process to determine copyright's proper scope.

When James Madison drafted the Patent and Copyright Clause of the Constitution, he was aware of the potential for abuse inherent in authorizing government to grant exclusive rights to individuals under patent and copyright. ${ }^{245}$ For that reason, Madison drafted the Patent and Copyright Clause both as a grant and a limitation of congressional power. Although he did not accept Thomas Jefferson's suggestion to limit the terıns of patent and copyright to a specified number of years ${ }^{2+6}$ he required patent and copyright to subsist only "for limited Times,"247 and he tied them to a public purpose-" $[$ t]o proinote the Progress of Science and useful Arts" ${ }^{248}$ - to ensure that copyright and patent continued to serve the public interest rather than the private interest of favored constituents.

${ }^{24}$ See Letter from Thomas Jefferson to James Madison (July 31, 1788), in 13 The Papers of Thomas Jefferson 440, 442-43 (Julian P. Boyd ed., 1956) (suggesting to Madison that the Constitution include a provision abolishing all governmentestabhished monopolies); Letter from James Madison to Thomas Jefferson (Oct. 17, 1788), in 14 The Papers of Thomas Jefferson 16, 21 (Julian P. Boyd ed., 1958) (responding that while government-established monopolies are "justly classed among the greatest nusances [sic] in Government," limited monopolies to encourage "hiterary works and ingemous discoveries ... are ... too valuable to be wholly renounced").

24 See Letter from Thomas Jefferson to James Madison (Aug. 28, 1789), in 5 The Writings of Thomas Jefferson 107, 113 (Paul Leicester Ford ed., 1895) (proposing the following language: "Art. 9. Monopolies may be allowed to persons for their own productions in literature \& their own inventions in the arts, for a term not exceeding - years but for no longer term \& no other purpose").

${ }^{24}$ U.S. Const. art. I, $\$ 8$, cl. 8.

24. Id. 
While Madison clearly foresaw the potential for abuse, his attempt to limit that potential has proven of httle avail, particularly with respect to copyright. Although copyright's term was initially limited to fourteen years plus a like renewal term, Congress has repeatedly extended its term so that it now stands at life plus seventy years. ${ }^{249}$ Although not precisely analogous, the fact that copyright's term now exceeds the life plus twenty-one years permissible under the rule against perpetuities strongly suggests that it is no longer for a "limited Time[]."250 Copyright once secured to authors the exclusive right to "primt, reprint, publish or vend"251 their work; it now grants authors a substantially broader set of rights, allowing an author to control almost any profitable use of her work or of other authors' variations on her work. ${ }^{252}$ And although copyright once limited protection to "maps, charts, and books,"253 it now protects a far wider range of subject matter, and ironically reserves its narrowest protection for the factual works that once represented two-thirds of its identified subject matter. ${ }^{254}$

Courts and commentators have pointed to changing teclmologies and changing markets as either justification for or explanation of

${ }^{249} 17$ U.S.C. $\$ 302(a)(2000)$. See generally William Patry, The Failure of the American Copyright System: Protecting the Idle Rich, 72 Notre Dame L. Rev. 907 , 915-33 (1997) (tracing the extension of copyright's term).

${ }^{250}$ Of course, the comparison is not precise. Where the rule against perpetuities formally reaches future interests created by an individual's private act, copyright is a present vested right created by statute. Nevertheless, both the rule against perpetuities and the constitutional provision restricting copyright to a "limited time" address the period over which an individual is given exclusive control over resources. Where the rule against perpetuities limits that period to a life plus one generation, copyright proponents are increasingly arguing for copyright extensions in terms of life plus two generations. E.g., Council Directive 93/98/EEC of 29 October 1993, Harmonizing the Term of Protection of Copyright and Certain Related Rights, 1993 O.J. (L 290) pmbl., item 5 (justifying a longer copyright term by suggesting that the "average lifespan in the Community has grown longer, to the point where [the standard] term [of life-plus-50] is no longer sufficient to cover two generations").

${ }^{251}$ Act of May 31, 1790, ch. 15, § 1, 1 Stat. 124, 124.

${ }^{252}$ Compare id. $\$ 6,1$ Stat. at 125 (prohibiting unauthorized "print[ing] or publish[ing]" of a copyrighted work), with 17 U.S.C. $\$ 106(1)-(6)$ (1994 \& Supp. V 2000) (granting the copyright owner the exclusive rights to reproduce, prepare derivative works from, distribute, publicly perform, or publicly display the copyriglited work).

${ }_{253}$ Act of May 31, 1790, ch. 15, pmbl., 1 Stat. 124, 124.

${ }^{244}$ Compare id. with Feist Publ'ns v. Rural Tel. Serv. Co., 499 U.S. 340, 348-49 (1991) (sharply limiting protection for works presenting factual information). 
this expansion. ${ }^{255}$ Certainly some parts of the expansion, such as the protection of computer programs in the 1980s and of sound recordings in the 1970s, were driven by changing forms of expression. But historically, very little of copyright's expansion can be tied to parallel changes in technology or markets. For example, Congress gave authors the exclusive right to translate their works in 1870 in response to Stowe $v$. Thomas. ${ }^{256}$ Yet there was no change im technology or markets that inight have justified this expansion. Just as someone could have done in 1790, Thomas had translated Stowe's work Uncle Tom's Cabin by hand and serialized the resulting work in his newspaper for his German-speaking customers in Pennsylvania. ${ }^{257}$ Similarly, Congress extended copyright protection to musical works in $1831,{ }^{258}$ adding the exclusive right to perform such works publicly in $1897^{259}$-well before the advent of radio and television. ${ }^{261}$ Given that the printing and public performance of musical works in the nineteenth century differed very little from that in the eighteenth, changing technologies or markets could not have justified this expansion. In fact, very httle of copyright's expansion in the United States over the last two hundred years can be tied to some contemporaneous change in technology or markets. ${ }^{261}$

Political pressure, not technology, has driven copyright's expansion. While those who produce works of authorship and those who consume such works share a common interest in ensuring a somewhat greater variety of works than the inarket would produce in the absence of copyriglit, they disagree over how extensive that protection should be. On the one hand, producers tend to favor

" E.g., Sony Corp. of Am. v. Universal City Studios, 464 U.S. 417, 430 (1984) ("From its beginning, the law of copyright has developed in response to significant changes in technology."); Adelstenı \& Peretz, supra note 41, at 209.

23 F. Cas. 201 (C.C.E.D. Pa. 1853) (No. 13,514), superseded by statute, Act of July 8,1870 , ch. $230, \$ 86,16$ Stat. 198,212 .

"1d. at 201.

sw Act of Feb. 3, 1831, ch. 16, § 1, 4 Stat. 436, 436.

${ }_{2 \times 4}$ Act of Jan. 6, 1897, ch. 4, 29 Stat. 481.

See Frederick Lewis Allen, Only Yesterday 164-65 (1931) ("[T]here was no such thing as radio broadcasting to the public until the autumn of 1920 , but ... by the spring of 1922 radio had beconie a craze ....").

${ }_{2 \times 1}$ Other expansions that are difficult to trace to any contemporaneous technological change include: Act of Apr. 29, 1802, ch. 36, \$2,2 Stat. 171, 171 (extending protection to prints): Act of Aug. 18, 1856, ch. 169, 11 Stat. 138 (extending protection to the public performance of dramas and plays). 
broader protection, reflected at the extreme by their demands for protection that would enable them to recover the full value of their work. ${ }^{262}$ Consumers, on the other hand, tend to favor somewhat narrower protection. While they may be willing to tolerate some copyright protection and the associated increase in prices, consumers quickly reach a point at which increasing variety is no longer worth its cost and broader protection becomes a wasteful and undeserved windfall for producers.

Although the Constitution seemingly prefers the interests of consumers over those of producers, copyright owners have enjoyed a decided advantage im the political contest over copyright's proper scope. ${ }^{263}$ Because there are fewer copyright producers, each producer has a higher individual stake in proposed copyright legislation than do individual consumers. Producers are therefore more likely to keep informed of, and seek to influence Congress on, proposed legislation. As compared to consumers, copyright producers are also better organized through mstitutions such as unions and trade associations, and therefore face decidedly lower transaction costs im organizing their lobbying efforts. Reduced transaction costs allow producers to present a more unified front to Congress and to obtain certain economies of scale in their persuasion efforts. Third, because of close ties within the industry, copyright producers can police their group more effectively to ensure that everyone contributes a proportionate share to the lobbying effort, minimizing the number that will free ride. Moreover, because the market shares of copyright producers are well known within their imdustries and because the marginal value of additional protection is closely related to market share, copyright producers can readily identify when one member of their group is

${ }^{262}$ E.g. Home Recording Hearings, supra note 205 ("The central principle on which this [royalty on home recording equipment] hinges is this: The right of those who create television programs and feature films to own what they create.") (statement of Jack Valenti, Motion Picture Association of America).

${ }^{263} \mathrm{On}$ the collective action and transaction costs advantages of concentrated interest groups generally, see Mancur Olson, The Logic of Collective Action: Public Goods and the Theory of Groups (1965); see also Glynn S. Lunney, Jr., A Critical Reexamination of the Takings Jurisprudence, 90 Mich. L. Rev. 1892, 1949-52 (1992) (summarizing the lobbying advantages available to a concentrated interest group). See generally Gordon Tullock, Rents and Rent-Seeking, in The Political Economy of Rent-Seeking 51 (Charles K. Rowley et al. eds., 1988). 
shirking. ${ }^{20}$ As a result, copyright producers have had and will likely continue to have disproportionate resources available for any given dollar amount at risk to press their case for broader copyright. ${ }^{265}$

The availability of disproportionate resources in political battles over copyright's proper scope has often meant disproportionate influence. This disproportionate influence is not necessarily a function of legislative bad faith, where legislators knowingly auction off the public interest for the campaign contributions and other benefits the copyright industry can provide. While the influence of a special interest group can take plainly illegitimate forms, such as bribery, ${ }^{266}$ even the inost well-intentioned legislator can be misled by the copyright industry's disproportionate resources. As a practical matter, these resources translate into a constant clamor where day after day, the legislator hears support for the measure, backed by impressive (and expensive) expert opimions. ${ }^{267}$ At the same time, the collective action difficulties facing consumers of copyrighted works mean that legislators will hear relatively little opposition from the other side. ${ }^{268}$ Given the apparent support for

${ }^{2}$ Paul Pecorino notes that cooperation may break down and the free-rider problem may prove more severe when there are "mformational problems relating to the unobservability of preferences. This would tend to create a difficult and well-known problem of assigning contribution shares which each party would have to meet to avoid triggering defection." Pecorino, supra note 160 , at 132.

${ }^{26}$ See Mancur Olson, The Rise and Decline of Nations 41 (1982) ("[S]mall groups have a greater likelihood of being able to organize for collective action, and can usually organize with less delay, than large groups. It follows that the small groups in a society will usually have more lobbying... power per capita ... than the large groups.").

${ }^{200}$ E.g., Daniel H. Lowenstein, Political Bribery and the Intermediate Theory of Politics, 32 UCLA L. Rev. 784, 848 (1985) ("It is a significant and politically relevant fact that under our present system of campaign finance, politicians and interest groups engage routinely... in felonious bribery that goes unprosecuted primarily because the crime is so pervasive.").

${ }^{2 h 7}$ As an example of one such expert opinion, see Home Recording Hearings, supra note 205 (memorandum of Laurence $H$. Tribe on constitutional law and copyright compensation). The Motion Picture Association of America also retained Professor Tribe to present its case personally to Senator Edward Kennedy. Lardner, supra note 31 , at 225.

26x Procedural fairness, pubhic hearings, and the like will not solve the problem. Because of transaction costs and collective action advantages, the concentrated interest group will be disproportionately represented at such ineetings. Indeed, the appearance of fairness such procedures create may itself enable the concentrated group to swing the law even more in its favor than they could in the absence of such procedural fairness. The apparent fairness of the procedure can, in effect, cloak a 
the measure and the apparent lack of opposition, enacting the measure seems sensible not only to the bought-and-paid-for legislator, but also to the legislator attempting to judge the merits of the measure fairly and impartially. ${ }^{269}$

Congress's imcreasing willingness to enact into law compromises crafted between those who create, those who publish, and those who provide the means to distribute works of authorship further diminishes the political voice of copyright's consumers. ${ }^{270}$ Ordinary consumers seldom play any direct role in the extended (and often private) negotiating sessions required to craft such compromises. The consumer interest is represented only indirectly in these sessions, when it happens to comcide with the imterest of one of the participants. Such coincidences are rare. As a general rule, all of those imvolved in the creation, publication, and distribution of copyrighted works share a common interest in maximizing their jomit revenue vis-à-vis consumers, whatever internecine fighting may develop over how to apportion that revenue amongst themselves. As a result, imdustry-crafted compromises are unlikely to reflect the interest of copyright consumers.

A mistaken view of copyright as a source of real economic growth has exacerbated these agency cost problems. For example,

considerable degree of substantive unfairness in the result, making it possible for the concentrated group to effect a statute that serves its interest to a greater extent than would be possible in the absence of the procedures.

${ }^{269}$ When Congress turns to governmental experts, such as the Register of Copyrights, the commissioner of the Patent and Trademark Office, or other im-house experts, looking for a neutral, objective evaluation, too often an overbroad copyright bias prevails. There is not only the self-selection problem, with lawyers choosing to specialize in copyright law because they believe more fervently in copyright's desirability than the average citizen, but also the problem of the revolving door. Government attorneys are well aware of whom, as between copyright producers and copyright consumers, they are more likely to represent when they leave the government's employ. See Pamela Samuelson, The U.S. Digital Agenda at WIPO, 37 Va. J. Int'l L. 369, 430 (1997) (notimg that intellectual property professionals tend by training to be "solicitious toward the interests of rights holders").

${ }^{270}$ See Jessica D. Litman, Copyright, Compromise, and Legislative History, 72 Cornell L. Rev. 857 passim (1987) (discussing the use of such compromises in drafting the 1976 General Revision of Copyright Law, Pub. L. No. 94-553, 90 Stat. 2541). The Senate Report accompanying the DMCA proudly boasts that "Chairman Hatch initiated comprehensive negotiations within the Judiciary Committee among copyright owners and Internet and online service providers to resolve the issue of service provider liability." S. Rep. No. 105-190, at 7 (1998). How the negotiations could be "comprehensive" when consumers were not represented is unclear. 
Senator Orrin Hatch, in arguing for passage of Senate Bill 2037 (the bill containing the DMCA), emphasized that in 1996 "the U.S. creative industries accounted for $3.65 \%$ of the U.S. gross domestic product" and that from 1977 through 1996, "the U.S. copyright industries' share of GDP grew more than twice as fast as the remainder of the economy." ${ }^{271}$ According to Senator Hatch, these and other numbers regarding the economic significance of the copyright industries leave "no doubt that copyright is of supreme importance to the American economy.",272

These numbers inask a key fact. Even if broadening copyright generates no real economic growth, it increases the price American consumers must pay for copyrighted works and transfers those additional revenues to copyright producers. Broadening copyright can thereby generate a real increase in revenue, and consequently GDP share, for the copyright industries even if it generates no real economic growth. A similar effect arises when the law allows copyright owners to claim a share of the value added to preexisting works by inprovements in distribution technology. By extending protection to a work regardless of the form in which it is conveyed or stored, ${ }^{273}$ copyright enables the owners of preexisting works to exact a fee on the use of the new distribution technology and to obtain thereby a transfer of wealth froin those who use and those who create the new distribution technology. When the new distribution

${ }^{271} 144$ Cong. Rec. S4884 (daily ed. May 14, 1998) (statement of Sen. Hatch); see also S. Rep. No. 105-190, at 10 (1998) ("The copyright industries are one of America's largest and fastest growing economic assets.").

$2 n 144$ Cong. Rec. S4884 (daily ed. May 14, 1998) (statement of Sen. Hatch).

${ }^{273}$ "Copies" is defined to include any form of the work (other than phonorecords). 17 U.S.C. $\$ 101$ (1994). As the Second Circuit explained in Matthew Bender \& Co. v. West Publishing Co., 158 F.3d 693, 702-03 (2d Cir. 1998):

This definition [of "copies" in $\$ 101]$ was intended to avoid the distinctions "derived fron cases such as White-Smith Publishing Co. v Apollo Co., 209 U.S. 1 [28 S. Ct. 319, 52 L.Ed. 655] (1908), under which statutory copyrightability in certain cases [had] been made to depend upon the form or niediun in which the work is fixed." H.R. Rep. No. 94-1476, at 52 (1976), reprinted in 1976 U.S.C.C.A.N. 5659, 5665; see also S. Rep. No. 94-473, at 51 (1975). . . . Thus, the definition of "copies" is intended to expand the "fixation" requirenient to include material objects that embody works capable of being perceived with the aid of a machine, thereby ensuring that reproductions of copyrighted works contained on media such as floppy disks, hard drives, and magnetic tapes would meet the Copyright Act's "fixation" requirement.

ld. at 702-03 (footnote omitted). 
technology at issue was not foreseen or anticipated at the time the preexisting work was created, it cannot plausibly be argued that this fee and wealth transfer served to encourage the work's creation. ${ }^{274}$ Instead, the transfer serves as a mere post hoc windfall. ${ }^{275}$ As a result, automatically extending the protection of preexisting works to new distribution technologies can increase the revenues and apparent GDP share of the copyright industries, even though the real source of the economic growth lies elsewhere.

In this hight, the fact that Senator Hatch has chosen the 1977 to 1996 time period to explore revenue and GDP share growth for the copyright industries is particularly troubling. With several substantial expansions in copyright protection during this period, such as the Copyright Act of $1976,{ }^{276}$ the Berne Convention Implementation Act of 1988, ${ }^{27}$ and the Sonny Bono Copyright Term Extension Act of $1998,{ }^{278}$ much of the apparent growth Hatch proudly cites inay not reflect productive economic activity, but a mere redistri-

${ }^{274}$ Cf. Michael H. Davis, Extending Copyright and the Constitution: "Have I Stayed Too Long?," 52 Fla. L. Rev. 989, 992-94 (2000) (noting constitutional difficulties with retroactive term extensions); Paul J. Heald \& Suzanna Sherry, Implied Limits on the Legislative Power: The Intellectual Property Clause as an Absolute Constraint on Congress, 2000 U. Ill. L. Rev. 1119, 1169 (noting that retroactive term extensions "cannot 'pronote the Progress of Science' in the way imtended by the framers of the Constitution"); Merges \& Reynolds, supra note 17, at 58-59 (noting constitutional difficulties with retroactive expansions). Courts avoid this logical flaw by focusing solely on whether licensing distribution through the new distribution technology would increase copyright owners' revenue without addressing whether providing that increase post hoc played any role im the work's creation. E.g., Basic Books v. Kinko's Graphics Corp., 758 F. Supp. 1522, 1534 (S.D.N.Y. 1991) (noting that allowing Kinko's to prepare course packages without paying a permission fee would reduce revenue for copyright owners and stating that "[t]his impact is more powerfully felt by authors and copyright owners of the out-of-print books, for whom permissions fees constitute a sigmificant source of income" without discussing whether expectation of such permission fees played any role in encouraging the creation of the works at issue).

${ }^{275}$ See Lardner, supra note 31, at 291 ("Most of the video dealers thought that Hollywood ought to be thanking them-and the electronics industry-for a new source of revenue, not only on current movies but on 'a lot of novies that were lying around in a vault somewhere.") (quoting Ira Goinberg, general counsel for Sony Corporation of America).

${ }^{276}$ Act of Oct. 19, 1976, Pub. L. No. 94-553, Title 17, § 101, 90 Stat. 2541.

27 Act of Oct. 31, 1988, Pub L. No. 100-568, 102 Stat. 2853 (codified as aniended at 17 U.S.C. $\$ 101$ (1994)).

${ }^{278}$ Act of Oct. 27. 1998, Pub. L. No. 105-298, Title 1, § 101, 112 Stat. 2827 (codified as amended at 17 U.S.C. $\$ 101(1994)$ ). 
bution of wealth. In addition, distribution technology for copyrighted works also radically advanced during this period, with the advent of cable, the videocassette recorder, and digital storage and transfer. Again, increasing revenue growth for the copyright industries during this period may reflect merely a monopohist's cut of the value added to preexisting works by the diligent and creative efforts of those responsible for these new distribution technologies, rather than productive economic activity im the copyright mdustries themselves. ${ }^{27}$

The hope, of course, is that by throwing money at copyright producers, more and better works will result. As discussed earlier, there is good reason to doubt that hypothesis, particularly given copyright's increased emphasis on maximizing revenues for the most popular works and the excess imcentives that systematically result. Whether the hypothesis is true, false, or something in between, however, focusing on copyright revenue and similar economic measures enables the increasingly substantial redistributive component inherent in broader copyriglit to masquerade successfully as productive economic activity.

Fearing the excesses that granting Congress unconstrained authority over copyright would create, the drafters of the Constitution entrusted courts with the final responsibility for ensuring that copyright serves primarily the public and not a private interest. Yet courts have largely abdicated that role. Although Justice Harlan Fiske Stone, in the famous Carolene Products footnote four, recognized the need for heightened scrutiny where the Constitution contains an express limitation on congressional power, ${ }^{280}$ courts have refused to impose a constitutional check on copyright's continuing expansion. ${ }^{281}$ Indeed, the judicial process has slown

${ }^{279}$ Moreover, this analysis omits the unproductive and wasteful expenditure of resources to ensure that such wealth transfers occur. See Merges \& Reynolds, supra note 17, at 55 ("From society's point of view, any expenditure on lobbying that might instead have been invested in research and development is a loss.").

2*u) United States v. Carolene Prods. Co., 304 U.S. 144, 152 n.4 (1938) (noting that there is a "narrower scope for operation of the presumption of constitutionality" where "legislation appears on its face to be within a specific prohibition of the Constitution, such as those of the first ten amendinents").

$2:$ See Eldred v. Reno, 74 F. Supp. 2d 1 (D.D.C. 1999) (upholding constitutionality of Sonny Bono Copyright Term Extension Act of 1998), aff'd, 239 F.3d 372 (D.C. Cir. 2001). 
symptoms that it too has been infected by the copyright industry's disproportionate influence. Although the prospects of campaign contributions or future employment are not likely to influence a judiciary appointed for life, the status of copyright plaintiffs as repeat players has offered the copyright industry a tremendous advantage in shaping the development of copyright doctrine.

As repeat players, copyright plaintiffs have the ability to decide which defendants to sue, which cases to bring, and in which order. ${ }^{232}$ This allows copyright plaintiffs to bring the right test casesthe ones in which they feel they have the best chance of winning. It also allows copyright plaintiffs to forum shop and pick the Circuit where they feel they have the best chance of winning. Moreover, because they are as interested in the development of copyright doctrine over time as the outcome in any given case, copyright plaintiffs can arrange cases agamst a number of similarly situated defendants in an order most likely to achieve a desired end result. For example, when video rentals first became popular, a group of unovie studios set out to obtain a judicial ruhing barring such rentals. ${ }^{283}$ Recognizing that the first sale doctrine posed a substantial obstacle to such a ruling, the studios began by suing a video rental store that offered in-store viewing. ${ }^{284}$ Furtherinore, the video rental store selected as the first defendant offered in-store viewing by transinitting the work from a VCR located in the front of the store through a cable to a viewing room in the back of the store. This instore transmittal differentiated the defendant's video rental opera-

280 Copyright defendants can bring their own test cases under the Declaratory Judgment Act, 28 U.S.C. $\$ \S 2201,2202$ (1994). See, e.g., On Command Video Corp. v. Columbia Pictures Indus., 777 F. Supp. 787 (N.D. Cal. 1991) (finding copyright infringement in response to plaintiff's declaratory judgment action seeking declaration of non-infringement). Their ability to do so, however, is severely limited by the "case or controversy" requirement of Article III. To bring a declaratory judgment action, the would-be plaintiff must demonstrate that the copyright owner "has either expressly or imphedly charged the plaintiff with imfringement." Sherwood Med. Indus. v. Deknatel, Inc., 512 F.2d 724, 727 (8th Cir. 1975) (describing requirement in patent cases); see also Diagnostic Unit Inmate Council v. Films Inc., 88 F.3d 651, 653 (8th Cir. 1996) (extending this rule to copyright cases).

${ }^{283}$ The studios pursued their ultimately unsuccessful efforts to persuade courts that ordinary video rentals constituted a public performance through a sequence of three cases. Columbia Pictures Indus. v. Prof'l Real Estate Investors, 866 F.2d 278 (9th Cir. 1989); Columbia Pictures Indus. v. Aveco, Inc., 800 F.2d 59 (3d Cir. 1986); Columbia Pictures Indus. v. Redd Horne, Inc., 749 F.2d 154 (3d Cir. 1984).

${ }^{234}$ Redd Horne, 749 F.2d at 156-57. 
tion from an ordinary rental store, and enabled the Third Circuit to find copyright infringement without directly confronting the first sale doctrine. ${ }^{285}$ Building on this success, the movie studios then sued a second video rental store that also offered in-store viewing. ${ }^{2}$ This video rental store did not, however, transmit the work. Rather, it merely rented rooms containing a VCR and television to its customers, and allowed its customers to perform the work for themselves. ${ }^{2 \times 7}$ Nevertheless, the Third Circuit, relying on its decision in the first case, found this to be an infringement as well. ${ }^{288}$

In doing so, the Third Circuit held that by offering the videotapes, equipment, and a room in which to view the copyrighted work to the public, the video store had publicly performed the work. ${ }^{284}$ At its broadest, the opinion suggested that by enabling any member of the public to perform a work, the video store violated the copyright owner's exclusive right to perform the work publicly, even if each individual performance of a work was private. ${ }^{290}$ Such a reading would readily extend to a more traditional video rental store. ${ }^{291}$ It too makes performances of the works possible for any member of the public, even though each individual performance is

${ }^{2 \times}$ Id. at $158-60$ (finding a public performance and concluding on that basis that the first sale doctrine did not apply).

${ }^{280}$ Aveco, 800 F.2d at 61.

${ }_{2 \times 7}$ Id.

${ }^{20 \times}$ Id. at 63.

2*x Id. ("Our opinion in Redd Horne turned not on the precise whereabouts of the video cassette players, but on the nature of Maxwell's stores. Maxwell's, like Aveco, was willing to make a viewing room and video cassette available to any member of the public with the inclination to avail himself of this service. It is this availability that made Maxwell's stores public places, not the coincidence that the video cassette players were situated in the lobby.").

2x) Id. Aveco argued that "while [the] viewing rooms are available to anyone for rent, they are private during each rental period, and therefore, not 'open to the public.' The performance-the playing of the video cassette-thus occurs not in the public lobby, but in tlie private viewing rooms." Id. By rejecting this argument as irrelevant, the Third Circuit implicitly suggested that the ultimately private nature of the individual performances that Aveco enabled through its rental operation was irrelevant to the public performance issue. See id.

${ }^{291}$ Lardner, supra note 31 , at 287-88 ("The people at Fox and Disney hoped the rental issue would be less controversial than the royalty. The repeated rental of a videocassette, it seemed to them, was no different in concept from a public showing of a movie in a theater, and the law ought to treat the two activities the same way-as commercial uses of a copyrighted work, to be allowed or disallowed at the copyright owner's discretion."). 
private. Fortunately for the public interest, the inovie studios' efforts to build these decisions into a prohibition on ordinary video rentals died when they filed their third case in this progression in the Ninth Circuit and lost. ${ }^{292}$ Although ultinately unsuccessful, the movie studios' ability to bring a progression of cases directed towards a desired end represents an advantage available uniquely to copyright plaintiffs.

As repeat players, copyright plaintiffs have also sought to shape copyright doctrine and preserve favorable rulings by buying settlements where necessary. ${ }^{293}$ When a copyright plaintiff obtains an initially favorable ruling fron a district or appellate court on a new issue, the copyright plaimtiff can offer a license to the infringing defendant at a token or below-market price. ${ }^{294}$ By settling with the defendant, the copyright plaintiff eliminates the risk that the initially favorable ruling will be overturned on appeal. Settling keeps the favorable ruling on the books as binding or persuasive authority that can become the basis for further expansions in copyright protection. Moreover, the rules of joinder, as well as the concentration and cohesiveness of the copyright producers, permit copyright producers to join together for test cases against any new, potentially infringing activity. ${ }^{295}$ This allows copyright producers to share

292 Columbia Pictures Indus. v. Prof'l Real Estate Investors, 866 F.2d 278, 281-82 (9th Cir. 1989) (rejecting a reading of the Third Circuit's reasoning that would extend the public performance doctrine to a hotel's rental of videodisks to its guests).

${ }^{293}$ As Paul Goldstein recounts, this approach is not new; it originated with the Stationers' Company. Goldstem, supra note 10, at 46-49 (following the Stationers' Coinpany's efforts to obtain a ruling establishing a perpetual common law copyright, including the use of settlement following a favorable lower court ruling to avoid a possible reversal on appeal).

204 Even before litigation begins, a copyright owner can offer a license with a token fee. After copyright consumers have accepted the token hicense fee, the copyright owner can then begin to raise the fee or use the existing token fee licenses as proof that a license market for the use exists. Id. at 219-23 (describing the use of such a "carrot-and-stick strategy" by the Copyright Clearance Center).

${ }^{295}$ Fed. R. Civ. P. 20(a) ("All persons may join in one action as plaintiffs if they assert any right to rehef jointly, severally, or in the alternative in respect of or arising out of the same transaction, occurrence, or series of transactions or occurrences and if any question of law or fact common to all these persons will arise in the action."). Thus, the recent cases against Napster and MP3.com were brought by a group of record companies. A\&M Records, Inc. v. Napster, Inc., 239 F.3d 1004 (9th Cir. 2001) (including plaintiffs A\&M Records, Geffen Records, Interscope Records, Sony Music, MCA Records, Atlantic Recording, Island Records, Motown Records, and Capitol Records); UMG Recordings, Inc. v. MP3.com, 92 F. Supp. $2 d 349$ (S.D.N.Y. 
the expense and allows each producer to influence the direction of the litigation. In contrast, the Federal Rules of Civil Procedure do not allow the test case defendant the same leeway to join other similarly situated parties for a joint defense. ${ }^{296}$ As a result, a tokenfee settlement offer is also disproportionately attractive to the target defendant. Rejecting the settleinent will force the target defendant to bear the cost of defense alone, even though the legal result the defendant is striving for would benefit many other similarly situated parties. Accepting the settlement, im contrast, gives the particular defendant express permission to continue its operation while creating the appearance that such express permission is required. Accepting the settlement thus not only enables the particular defendant to ensure its own contmued existence, but also increases the pressure on the defendant's would-be competitors to obtain a similar license at a no longer token-fee price. For these reasons, an individual defendant may accept a settlement offer that a unified defense would have rejected. ${ }^{297}$

While these repeat player advantages in the judicial process are not foolproof, they offer copyright plaintiffs a unique opportunity to skew the judicial process towards broader protection. The net result has been that courts, rather than serving as guardians of the public interest that the Constitution enshrines, have been participants in copyright's capture.

These advantages in the domestic arena have only grown as the question of copyright's proper scope has become imcreasingly im-

2000) (including plaintiffs UMG Recordings, Sony Music, Warner Bros. Records, Arista Records, Atlantic Recordings, BMG Music, Capitol Records, Elektra Entertainment, Interscope Records, and Sire Records).

${ }^{2 *}$ Fed. R. Civ. P. 14(a) (allowing a defendant to bring in a third party only where the third party "is or may be liable to the third party plaintiff for all or part of the plaintiff's claim against the third-party plaintiff"); see also Rose v. Chi., Rock Island \& Pac. R.R., 308 F. Supp. 1357, 1361 (W.D. Okla. 1970) (noting that a defendant is allowed to join a third party only if the third party is derivatively hable to the defendant for the plaintiff's loss; a defendant may not otherwise join another, alternative defendant).

${ }^{297}$ In recent years, important cases have been settled while a petition for certiorari was pending before the Court. See, e.g., Am. Geophysical Union v. Texaco, Inc., 60 F.3d 913 (2d Cir. 1994) (finding that copying of scientific journal articles for Texaco research scientists constituted unfair use), cert. dismissed, 516 U.S. 1005 (1995). Others have been settled following the issuance of a preliminary injunction. See, e.g., West Publ'g Co. v. Mead Data Cent., 799 F.2d 1219 (8th Cir. 1986), cert. denied, 479 U.S. 1070 (1987). 
ternational. As students of political systems have long known, parliamentary systeins, because they lack an independently elected chief executive and offer a viable role for third parties, are particularly susceptible to special interest group influence. ${ }^{298}$ Moreover, until recently under the aegis of the European Union, much of Europe lacked a strong and coherent antitrust enforcement policy. ${ }^{299}$ As a result, copyright owners' influence was relatively stronger in Europe than in the Umited States, and the important counterweiglit that deadweight losses and other monopoly consequences of overbroad copyright could offer was diminished. Given these two considerations, copyright in many European countries has long provided more extensive protection tlan copyright in the United States. ${ }^{300}$ Negotiations with Europe concerning copyright's proper scope have led almost inevitably to an increase in the scope of protection that draws American copyright further from the public interest that it is supposed to serve. ${ }^{301}$ The fact that Congress has empowered unelected officials to conduct these negotiations, ${ }^{302}$ with the results often presented to Congress as part of a larger

${ }^{298}$ The need for separation between the legislative and executive branches played a prominent role in the Constitutional Convention and in the creation of the constitutional provision for an inidependently elected chief executive. As James Madison explained, quoting Montesquieu: "There can be no liberty where the legislative and executive powers are united in the same person or body of magistrates. ..." The Federalist No. 47, at 270 (James Madison) (Clinton Rossiter ed., 1961). For further elaboration on the need for an executive independent of the legislative branch, see The Federalist Nos. 48, 49, 51 (James Madison), Nos. 71, 73 (Alexander Hamilton).

${ }^{299}$ Gabriele Dara, Antitrust Law in the European Community and the United States: A Comparative Analysis, 47 La. L. Rev. 761, 762 (1987) ("On the other side of the Atlantic the statutory reaction to anti-competitive practices was much slower. Apart from the Monopolies and Restrictive Practices (Inquiry and Control) Act of 1948, passed in the United Kingdom, and the West German Gesetz gegen Wettbewerbsbeschzakungen of 7.27.1957, none of the other European countries developed any substantial antitrust legislation prior to the establishment of the EEC."); Francis G. Jacobs, Civil Enforcement of EEC Antitrust Law, 82 Mich. L. Rev. 1364 (1984).

${ }^{300}$ Samuelson, supra note 269, at 394 ("Also noteworthy is the fact that the United States has been a member of the Berne Union for less than a decade, whereas the Europeans have been the dominant players in Berne Convention negotiations since its inception. As welconie as the belated U.S. conversion to high protectionist norms might be, many Europeans remember the errant nature of earher U.S. ways.").

${ }^{301}$ Id. at 430.

${ }^{302}$ Id. at 429-30. 
package deal, only compounds this quiet trampling of the public interest."

Taken together, the advantages available to copyright owners in the political and legal battles over copyright's scope do not mean that copyright owners will win every battle over copyright's expansion. Even with their disadvantages, consumers may on occasion rise up and defeat proposals for broader protection. Nevertheless, these advantages mean that copyright owners will win more such battles than they should. Whatever occasional defeats for broader protection occur will likely prove only temporary setbacks, ${ }^{304}$ and the disproportionate influence of copyright owners should prove decisive over the long run. A process biased in favor of overbroad protection will lead, sooner or later, to a similarly biased result. For that reason, traditional political avenues of opposition to copyright's evolution from pubhic interest to private interest will likely fail. If copyright has not yet been fully captured by the industry it is supposed to regulate, it is only a inatter of time.

Private copying, as a form of civil disobedience, can help counter copyright's capture. Since its role in the founding of this nation, civil disobedience has remained a vital force in our civic lives. ${ }^{305}$ In the face of unjust laws, which copyright laws have increasingly become, an individual has no choice but to withhold her consent and

${ }^{003}$ See id. at 409-15 (noting that the anti-circumvention provisions of the putative DMCA closely track language that U.S. delegates proposed for the WIPO treaty on anti-circumvention, but that was rejected by other delegations as too restrictive).

Although the MPAA and Columbia Pictures could not obtain a ruling barring video rentals from either Congress or the courts, respectively, they managed to persuade the U.S. trade representative to insert a provision barring video rentals under certain circumstances into the Agreement on Trade Related Aspects of Intellectual Property. Agreement on Trade Related Aspects of Intellectual Property Rights, Apr. 15, 1994, Marrakech Agreement Establishing the World Trade Organization, Annex 1C, Legal Instruments-Results of the Uruguay Round vol. 31, 33 I.L.M. 81, $\$ 1$, art. 11, (1994) (requiring Members to "provide authors ... the right to authorize or to prohibit the commercial rental to the public of originals or copies of their copyright works," but excepting Members from this obligation for cinematographic works where such rental has not "led to widespread copying").

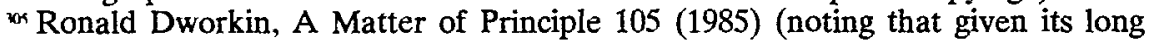
history in American politics, "civil disobedience has a legitimate if informal place im the political culture of [the American] community"). See generally Civil Disobedience in America: A Documentary History (David R. Weber ed., 1978) (collecting American writings on civil disobedience from the seventeenth through the twentieth centuries). 
force government to confront squarely the injustice it seeks to impose. ${ }^{306}$ Although private copying can serve as a form of civil disobedience, it will prove effective only if copyright requires visible enforcement actions against ordinary citizens. Only such actions will convince the ordinary consumer that she too is affected by overbroad copyright. A reading of the DMCA that severely restricts access to decryption technology would likely confine the abihity to engage in private copying to an isolated technological elite. Because copyright owners could more readily scapegoat such an isolated elite as dangerous "hackers" or pernicious "pirates," strict reading of the DMCA would likely defeat the effectiveness of private copying as a form of civil disobedience.

Such a result is undesirable. Think of copyright as a $\operatorname{tax}^{308}$ If copyright owners.are allowed to enforce their rights through an effective technological lock, the full extent of the copyright tax remains invisible to the typical consumer. Unaware of the tax they are paying, consumers will fail to oppose it as vigorously as they should, compounding the transaction cost and collective action dis-

${ }^{306}$ See Richard A. Vachon, The Relevance of St. Thomas More, 13 Cath. Law. 145, 147 (1967) (noting that one goal of civil disobedience is to call attention to an unjust act of the government); Paul J. Weber, Toward a Theory of Civil Disobedience, 13 Cath. Law. 198, 202 (1967) (noting that civil disobedience is a form of protest against injustice); see also Michael Walzer, Obligations: Essays on Disobedience, War, and Citizenship, at xi-xii (1970) (arguing that a government is only just when the governed have consented to the exercise of authority over themselves); Bruce Ledewitz, Civil Disobedience, Injunctions, and the First Amendment, 19 Hofstra L. Rev. 67, 90-91 (1990) (describing civil disobedience as a "conscientious protest" that "encourage[s] citizens to keep faith with themselves").

${ }^{307}$ See S. Rep. No. 105-190, at 8 (1998) (referring to need to provide copyright owners with reassurance "that they will be protected against massive piracy" that the Internet would otherwise create); H.R. Rep. No. 105-551, pt. 2, at 25 (1998) (asserting that "digital technology enables pirates to reproduce and distribute perfect copies of works-at virtually no cost at all to the pirate"); id. pt. 1, at 9 (1998) ("While such rapid dissemination of perfect copies will benefit both U.S. owners and consumers, it will unfortunately also facilitate pirates who aim to destroy the value of American intellectual property.").

${ }^{303}$ As Lord Macaulay long ago explained:

The principle of copyright is this. It is a tax on readers for the purpose of giving a bounty to writers. The tax is an exceedingly bad one; it is a tax on one of the most innocent and most salutary of human pleasures; and never let us forget, that a tax on innocent pleasures is a premium on vicious pleasures.

Speech of Thomas Babington Macaulay on Copyright (Feb. 5, 1841), in 1 Thomas Babington Macaulay, Miscellanies 235, 243 (1900). 
advantages consumers already face. ${ }^{309}$ But requiring copyright owners to pursue infringement actions against ordinary consumers directly increases the likelihood that consumers will become aware of the full extent of the copyright tax they are paying, and improves the chance that consumers will participate actively, either directly or through civil disobedience, in the political debate over copyright's proper scope.

In a sense, the ability to engage in private copying empowers ordinary consumers to set the appropriate level of protection for creative works. Such empowerment should not be taken as excuse or license for consumers to copy without consideration of the consequences. At the heart of civil disobedience is a willingness to accept the official consequences of breaking an unjust law. ${ }^{310}$ Should consumers begin copying too freely, copyright owners remain free to bring the full weight of the law down on them, thus provoking a political confrontation regarding copyright's just and proper scope. Yet, requiring copyright owners to act directly against ordinary citizens helps ensure that the resulting political battle is more balanced. Rather than a disorganized and unaware populace, copyright owners will confront a fully aroused and fully aware citizenry. Even with their transaction costs and collective action advantages, copyriglit owners should fear sucli a confrontation.

Until copyright owners are prepared to place their privileges at risk through such a confrontation, ordinary citizens should be free to engage in private copying and to determine the proper level of protection for themselves, rather than through their elected representatives. Such an approach requires copyright owners to make their case for broader protection to consumers directly. Because these are the same consumers that will bear the full costs of

${ }^{309}$ In addition, because government has authorized copyright owners to collect the tax for themselves, revenues from the copyright tax never flow through the government's coffers where their expenditure on works of authorship could be forced to compete against other, more deserving programs.

${ }^{10}$ See A.D. Woozley, Law and Obedience: The Arguments of Plato's Crito 141, 141-56 (1979) (presenting Socrates' view that an individual should accept even unjust punishment for violating an unjust law); Martha Minow, Breaking the Law: Lawyers and Clients in Struggles for Social Change, 52 U. Pitt. L. Rev. 723, 733 \& n. 38 (1991) (defining civil disobedience as "open acts violating the law accompanied by a willingness to accept the official consequences"); Weber, supra note 306, at 202. 
broader protection, they are likely to prove a far more skeptical audience than elected representatives who bear only a tiny fraction of broader protection's costs. Setting protection levels through a direct democratic process thus avoids the agency-cost problems associated with representative democracy.

Even if some free riding ships by, in the guise of civil disobedience or otherwise, the empirical evidence suggests that voluntary comphance will likely prove sufficient to achieve a fair and efficient level of effective protection. ${ }^{311}$ As a result, private copying as a form of direct democracy is likely to bring protection levels more in line with the public welfare than is strong encryption-based protection.

\section{THE ALTERNATIVES REVISITED}

Revisiting the alternative approaches for controlling the potential threat that private copying poses to the production of creative works, this Article suggests that interpreting the DMCA to incorporate directly copyright's longstanding limitations on protection, such as the fair use doctrine, would advance copyright's public purpose. Federal law that enabled copyright owners to employ encryption to protect their works as they see fit would likely prove both undesirable and unconstitutional. Instead, copyright should rely on some mixture of weak encryption and faith in American consumers to ensure an adequate level of protection. If more protection proves necessary to ensure "the progress of Science," a limited tax on copying technology and blank storage media would likely prove far more consonant with the Constitution's public interest requirement than a strong encryption-based regime.

Although it is initially tempting to reject an approach that incorporates a fair use defense into the DMCA's anti-circumvention provisions directly, a closer look at private copying illustrates the benefits of such an approach. The initial temptation arises because incorporating a fair use defense into the DMCA, while ensuring access to decryption technology for those with a fair or otherwise non-infringing use for such technology, would also inevitably place decryption technology in the hands of those intending an infringing

${ }^{311}$ See supra text accompanying notes 158-77. 
use. As a result, incorporating the fair use defense into the DMCA would not recapture the balance that copyright and the fair use doctrine have established over the last two hundred years. It would simply open the door to widespread private copying. Moreover, such private copying would essentially be uncontrolled because the technological lock would be broken and copyright's traditional individual lawsuit approach would prove prohibitively expensive. This creates an all-or-nothing choice between having effective technological protection and not having effective protection at all. Given this choice, copyright's traditional incentives-based analysis suggests that we choose effective technological protection even if such protection bars otherwise fair or non-infringing uses. After all, the traditional analysis seductively whispers, it is better to have the works, albeit at a higher price, than risk not having them at all.

A closer look at private copying suggests that we can have our works and lower prices too. Given the popularity networks inherent in the marketing of creative works and given copyright's valuebased expansion over the last century, copyright protection has increasingly awarded copyright producers exceedingly large returns for the most popular works, while providing only slight encouragement to the marginal works that represent copyriglit's true public purpose. To the extent that private copying increases with the popularity of a work, private copying is not likely to reduce materially the incentives necessary to ensure the production of the marginal works. Instead, private copying will simply enable consumers to recapture the excess incentives otherwise given to more popular works. In addition, by reducing excess incentives, private copying will tend to remove the distortion and discouragement that excess incentives will otherwise introduce into the authorship process. Finally, private copying can enable consumers to set the appropriate level of copyright protection directly, rather than through their elected representatives. Private copying can thereby reduce the agency-cost mistakes that a representative government would otherwise introduce into the process of defining copyright's proper scope and bring the protection available for creative works more in line with the overarching public interest.

If further protection is warranted, neitlier a strong encryptionbased approach nor a levy-based approach is likely to balance perfectly the public and private interests at stake. As between them, 
however, a limited tax on copying technology and storage media is likely to prove more desirable. This conclusion was personally surprising, yet it appears inescapable. Although three difficulties arise with a levy-based approach, comparable problems arise and are likely to prove more substantial with strong encryption-based protection. Moreover, a levy-based approach offers two clear advantages over strong encryption in tailoring protection to serve the pubhic interest: (1) directing incentives towards the marginal, rather than the non-marginal, work; and (2) ensuring a more balanced political battle over the proper level of protection.

The first difficulty that a levy-based approach presents is that a uniform levy on copying technology and storage media artificially inflates the price of such equipment and also requires those using the technology for legitimate purposes to pay tribute to copyright owners. Yet, a strong encryption-based approach entails a similar cost by denying access to decryption technology to those intending a fair or otherwise legitimate use of a copyriglited work. Thus, both approaches, in attempting to address the risk of private copying, treat legitimate users of the technology as if they were illegitimate infringers. In that sense, the two approaches are equally inefficient and equally unfair to those intending a legitimate use. As between thein, however, a levy-based approach is better able to allow for legitimate uses, for example by exempting certain types of recording equipment or by granting certain institutions exemptions from the levies. ${ }^{312}$

The second difficulty is that a uniform levy discourages the creation and introduction of new and innovative distribution technologies by forcing inanufacturers to turn over a portion of the rents associated with their innovation to copyright owners. But a strong encryption-based approach lias similar effects. ${ }^{313}$ Because

\footnotetext{
${ }^{312}$ See 17 U.S.C. $\$ 1001$ (3) (1994) (excluding "professional model products" from the general definition of a "digital audio recording device").

${ }^{313}$ From the mid-1970s through its expiration in March 1993, Congress gave the President fast-track authority to negotatiate trade agreements. See Steve Charnovitz, No Timie for NEPA: Trade Agreements on a Fast Track, 3 Minn. J. Global Trade 195, 201-04 (1994). With the fast track procedure, Congress agreed in advance not to amend trade agreements proposed by the President and also agreed to vote on such agreements within sixty days of their proposal. Id. Although the fast track procedure expired in March 1993, responsibility for negotiating international intellectual property agreements still fell to unelected administration officials. See Samuelson,
} 
new distribution technologies and copyrighted works are complements, extending protection for preexisting copyrighted works to new forms of distribution enables copyright owners to extract a full monopolist's share of the value added by the new technology. ${ }^{314}$ It thereby reduces the rents available for innovative distribution technologies and increases the effective price of such technologies to consumers. ${ }^{315}$ To the extent that encryption enables copyright owners to price discriminate more effectively, it will allow copyright owners to capture that much more of the value added by the new distribution technologies, leaving that much less to encourage their innovation.

The third difficulty is that a uniform levy expressly authorizes private copying and may therefore convert private copying from a marginal to a mainstream activity. Although this difficulty is troubling, a levy-based approach at least has the virtue of acknowledging reahty. Given that private copying is hikely to continue, retaining a formal prohibition on private copying that is

supra note 269, at 430 (noting that Commissioner Lehman "alone would be in charge of presenting the U.S. position" at the December 1996 WIPO meeting to discuss proposed treaties for updating intellectual property protection to reflect digital technologies).

${ }^{314}$ See Ward S. Bowman, Jr., Patent and Antitrust Law 70-76 (1973) (using an example from patent law); Richard A. Posner, Antitrust Law 173 (1976). The classic example economists offer to explore the relationship between complements and market power concerns shoes. Assume, for example, that consumers are uniformly willing to pay $\$ 10$ for a pair of shoes, and that a pair of shoes costs $\$ 5$ to make. In a perfectly competitive market, a pair of shoes will cost $\$ 5$. If a single entity controls the production of shoes generally, then it will raise prices to $\$ 10$ and earn a monopoly profit of $\$ 5$ per pair. Yet, to earn such a monopoly profit, the entity need not have a monopoly over the production of all shoes; it is sufficient if the entity has a monopoly over the production of left shoes alone. If right shoes are produced in a perfectly competitive market and sold at their cost of $\$ 2.50$ per shoe, then our left shoe monopolist can earn the same $\$ 5$ monopoly profit per pair by selling left shoes at $\$ 7.50$ each. Although the problem becomes more comphcated with more realistic cost and demand functions, the shoe example establishes the basic principle that with complements, sometimes a monopoly on one of the necessary products is as good, from the monopolist's point of view, as a monopoly on both or all of the necessary products. See Lunney, supra note 194, at 39-40.

"If both the manufacturer of the new distribution technology and the copyright owners enjoy market power, the fact that the technology and copyrighted works are compleinents may lead to a double monopoly mark-up on the price consumers must pay for the combination of the two. See Bowman, supra note 314, at 72; Varian, supra note 148, at 463-65. In such a case, as Professor Varian explains, "[t] he price is not only too high from a social point of view, it is too high from the viewpoint of maximizing total monopoly profits!" Id. at 465. 
routinely ignored has costs as well. ${ }^{316} \mathrm{~A}$ levy-based approach would also avoid the Ninth Circuit's unseemly condemnation of Napster users as copyright infringers both en inasse and in abstentia. ${ }^{317} \mathrm{Al}$ though the Ninth Circuit's ruling is not binding against Napster users, ${ }^{318}$ any approach that requires a blanket finding of infringement against an unrepresented party (or a very large number of unrepresented parties) raises the specter of judicial and governmental over-reaching. Perhaps the Ninth Circuit would have reached the same conclusion even if the millions of Napster users had individually presented their cases to the court, although, as Justice John Paul Stevens noted in his initial draft dissent in the

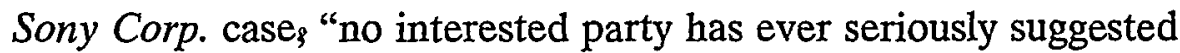
that a penalty, or any form of statutory hability, should be imposed upon an individual for making a single copy of any copyrighted work for his own private use."319 Given that the individual Napster users had no opportunity to be heard, the Ninth Circuit's conclusions regarding the propriety of their actions are inherently suspect. In addition, the harm that may result from formally acknowledging private copying must be balanced against the harm that will result from formally converting the protection of creative works from copyright into guild monopoly. Unjust laws always carry a price. The price of turning our system of protecting creative

${ }^{316}$ For example, given that home audio-taping had been going on for years without any legal action by the copyright owners, it is quite incongruous to read a statement asserting that such behavior is, was, and always has been illegal. Compare Burt A. Leete, Betamax and Sound Recordings: Is Copyright in Trouble?, 23 Am. Bus. L.J. 551,557 (1986) ("Clearly, home audio recording of copyrighted material is illegal under the current Act and may always have been."), with Lardner, supra note 31, at 215 ("Besides, [the MPAA] worried that the abihty to record copyrighted music free of charge had become so commonplace and so undisputed that it could no longer be challenged; and they worried that the video royalty would become tainted by association.").

${ }^{313}$ A\&M Records, Inc. v. Napster, Inc., 239 F.3d 1004, 1014 (9th Cir. 2001) ("Napster users who upload file names to the search index for others to copy violate plaintiffs' distribution rights. Napster users who download files containing copyrighted music violate plaintiffs' reproduction rights.").

${ }_{318}$ Under the rules of estoppel, a party not present caunot be bound by an earlier decision. Parklane Hosiery Co. v. Shore, 439 U.S. 322, 327 n.7 (1979) ("It is a violation of due process for a judgment to be binding on a litigant who was not a party or a privy and therefore has never had an opportunity to be heard.").

${ }^{319}$ Goldstein, supra note 10, at 152 (reprinting a portion of Justice Stevens' proposed dissent). 
works over to the private interests of copyright producers will prove high indeed.

Moreover, as compared to a strong encryption-based approach, a levy-based approach offers two clear advantages. First, rather than simply maximizing revenue for the most popular works, a levy-based approach can be tailored to increase the revenue available to marginal works. In Europe, a number of countries specifically require a certain percentage of the levy funds to be set aside for specified social and cultural purposes. ${ }^{320}$ Some countries allocate additional shares of the levies for certain types of works; others allocate a specified percentage to new authors. ${ }^{321}$ Although questions may arise over how these "discretionary" funds are allocated, simple modifications to the formula for calculating shares can redistribute revenue from the most popular works to the marginal works. ${ }^{32}$ Through such manipulation, a levy-based approach may encourage the production of marginal works and ensure a bet-

(2) Deloitte \& Touche, supra note 135, at 60 ("French legislation of 1985 strengthened the role of promotion of cultural life by obligating the SGCs [collective rights organizations] to allocate $25 \%$ of the remunerations for private copying and $50 \%$ of the non-distributable sums arising from the public broadcasting of recordings [to social and cultural purposes]."). Members of the collective rights organization are typically entitled to control disbursement of the levy portion set aside for social and cultural purposes. Id. ("Control of the use of the funds allocated for social and cultural expenditure and of the non-distributable sums: the allocation of the sums in question is generally part of the member control carried out by the menbers of the SGC ....").

"2! See Gröndahl, supra note 142 ("Characteristically, France reserves 25 per cent of the proceeds from hardware sales for a fund to promote young or avant-garde artists.").

${ }^{122}$ For example, take the Nielsen ratings for January 18 to January 24, 1999. Nielsen Ratings, Jan. 18-24, 1999 (Jan. 27, 1999), at http://nielsen_ratings.tripod.com/nielsen8.htm. Allocating the private copying levies to each of the 125 identified prime-time slows by the show's Nielsen rating as a fraction of the total Nielsen ratings, the most popular show would receive $2.65 \%$ of the levies and the two least popular shows would each receive $0.037 \%$ of the levies. The two least popular shows would therefore receive levy revenue only $1.4 \%$ of that received by the most popular show. If, however, we allocate each of the 125 shows one point to start with and then allocate revenue by a fraction equal to (a show's Nielsen rating plus one) divided by (the total Nielsen ratings plus 125), then the most popular show would receive $2.4 \%$ of the levies and the two least popular shows would receive $0.14 \%$. As a result, while the two least popular shows would still receive less levy revenue, under this system, they would each receive levy revenue equal to $5.8 \%$ of that received by the most popular show-a more than four-fold mcrease of their relative shares. 
ter fit between our system of copyright protection and the public interest in encouraging additional works.

Second, a government-set levy is likely to be more fair and efficient than prices set by the copyright industry and enforced through strong encryption-based protection. Although David Ladd lias denounced compulsory licenses as government meddling with the inarket, ${ }^{323}$ the notion that prices for copyrighted works are independent of government meddling is facially absurd. Prices for copyrighted works are a direct function of the level of copyright protection the government has provided. The notion that the prices resulting from any given level of government-provided protection are someliow natural or efficient is simply mistaken. If the government provides too mucli protection, prices will be inefficiently high (or perhaps, output will be too low). ${ }^{324}$ Moreover, even if copyright were perfectly tailored to the public interest and only went so far as to correct the market failure associated witl the production of creative works, popularity networks and other natural monopoly characteristics of copyrighted works, as well as the concentration of the copyright industries, ${ }^{325}$ would likely ensure that the resulting market prices were neither fair nor efficient. Strong encryption-based protection is likely to worsen this problem by enabling the copyriglit industries to exploit their market power more fully, further distorting the allocation of scarce resources sucli as creativity.

${ }^{32}$ Ladd, supra note 199 , at 431 ("Whatever one thinks of the comparative merits of national economic planning and free markets, or of government as an instrument of wealth distribution, our government should abstain as much as possible from intervention in the copyright world, and wilhingly forebear from setting or affecting the value or price of works of authorship."). The sentiment is a curious one given that Mr. Ladd's opinions on the issue were important primarily because of his position as Register of Copyrights.

${ }^{324}$ Prices and output usually work hand-in-hand. An individual can set a high price only if she can reduce her output, and will reduce her output only if she can receive a higher price in return. For authors, however, who do not enjoy their own market power but are simply following the prices set by more popular authors, we might think of price and output as separate (or at least separable) decisions.

${ }^{325}$ See Hayes, supra note 221, at 9 (displaying chart that attributes $70.4 \%$ of the domestic box office in 2000 to six movie studios); Rick Karr, Record Labels Begin to Respond to Settlement Offer Napster Made Public Yesterday, All Things Considered, Feb. 21, 2001, LEXIS, News Library, National Public Radio File (noting that the five inajor record labels in the Napster case had a market share of roughly $75 \%)$. 
By challenging the copyright industries' unilateral power to set prices, adoption of a government-set levy would ameliorate the inefficiency that a strong encryption-based regime and its associated high prices would bring. By setting levies at a level below that required to equalize the market price of an authorized copy and the cost of making a copy privately, the government can enable private copying to become a source of competition that exerts downward pressure on the authorized copy's market price. ${ }^{326}$ To the extent that the "Inarket" price would otherwise reflect monopohistic elements or over-broad copyright protection, such coinpetitive pressure can bring market prices closer to the competitive ideal. ${ }^{327}$

Undoubtedly, the copyright industries will attempt to use their transaction cost and collective action advantages to persuade government to set a levy sufficiently high so that private copying does not pose a threat to their market power. Yet, with a levy-based approach, the tax is readily visible and therefore inore likely to raise consumers' ire. The political battle over the proper levy may not therefore prove as lopsided as the battle over copyright's proper scope. Moreover, levies on copying equipinent threaten directly the sales and profits of those who manufacture and distribute copying equipment. While an interest group with its own agenda cannot always serve as an effective representative for consuniers generally, in the case of levies, the interest of equipment inanufacturers are likely to parallel closely the interests of consumers. Equipinent manufacturers are also better organized, inore concentrated, and more cohesive than consumers, and should therefore be more effective at opposing high levies. Indeed, equipinent inanufacturers enjoy transaction costs and collective action advantages comparable to those enjoyed by the copyright imdustries, making the two well matched as political opponents on the levy issue. Rather than seeing and hearing only one side of the story, legislators and gov-

${ }^{23}$ If a $C D$ in the store costs $\$ 14.95$, and a private copy of the $C D$ can be made for \$0.95, then the levy on the blank CD will determine the ultimate price of the private copy. A high levy of $\$ 14$ per blank CD will make the average consumer indifferent between the private copy and the store-bought copy (assuming the two CDs are otherwise identical and that all costs are fully incorporated in the $\$ 14.95$ price). A levy in excess of $\$ 14$ will lead the average consumer to forego private copying. A levy below $\$ 14$ may lead some consumers to switch to private copying and place competitive pressure on the copyright owner's $\$ 14.95$ price.

${ }_{227}$ Lunney, supra note 182 , at 449. 
ernment officials will see and hear both sides. In contrast to the decidedly uneven battles between the copyright industries and consumers over copyright's proper scope, this more balanced political battle between the copyright industries and equipment manufacturers over levies would enable Congress to set levies at an efficient and fair level. ${ }^{328}$

\section{CONCLUSION: PREPARING COPYRIGHT FOR THE DIGITAL MILLENNIUM}

As we begin a new millennium, we face a choice both as to how, and more importantly why, we protect creative works. As to the low, Congress's premise in enacting the DMCA was sound: Digital technology has fundamentally altered the landscape. In the face of widespread private copying, copyright's traditional approach of direct legal action against the individual copier, while sensible in the last millennium, has become increasingly unworkable. When the copiers number in the millions, it is simply impractical to attempt to control their behavior through lawsuits directed at each individual. While copyright's traditional approach will remain important for protecting non-digital works and for controlhing traditional forms of infringeinent, addressing widespread private copying will require a different approach. For that reason, the methods of protection of creative works in a digital environment need to change. Yet, digital technology justifies no similar change in the underlying reasons to protect creative works. Even if digital technology has rendered copyright's direct legal action paradigm anachronistic, copyright's more fundamental message remains as timely today as when first spoken in the Statute of Anne nearly three hundred years ago: Protection of creative works should serve the public, and not inerely a private, imterest.

In designing protection for the digital age, we nuust first determine whether the possibility of widespread private copying

${ }^{328}$ Thus, in contrast to the steady expansion of copyright protection, opposition from consumers and manufacturers has kept levy rates on private copying equipment at a constant level in Germany since 1986. Kreile, supra note 136 ("As one of the imminent next steps, the Minister of Justice subsequently announced an increase in copyright royalties in the sector of private copying, since statutory remuneration, having remained unchanged for fourteen years, has led to a 'wage freeze' for authors."). 
threatens the public interest in ensuring an adequate supply and distribution of creative work, or merely the private interest in maximizing the copyright industries' revenue. Although the copyright industries have been quick to proclaim their doom should we fail to address the risk of widespread private copying, their cries in this regard are not new. During the hearings surrounding the Sony Corp. decision, one of the law finns representing the Motion Picture Association of America boldly proclaimed: "Unless Congress acts to compensate copyright owners for the hoine taping of their intellectual property, the audiovisual marketplace will become a barren wasteland of programming that does not edify, nor inspire nor entertain. ${ }^{\prime 329}$ More than a decade and a half later, it is obvious that the copyright industries were exactly wrong in predicting the likely effects of home videotaping.

A closer look at private copying suggests that the copyright industries are equally wrong in their predictions with respect to digital technology. Private copying inay reduce the excessive incentives currently given the most popular works, but is unlikely to reduce revenues for less popular, inarginal works. Whatever threat private copying poses to the private interest of the copyright industries, it poses no threat to the public interest.

Although constitutionally constrained to serve the public interest, Congress has nevertheless embraced a strong encryption-based approach to preventing private copying and has thereby turned its responsibility for defining the proper scope of protection for creative works over to the copyright industries. In doing so, Congress has recreated an approach to protection that relies on technological controls backed by legal prohibition-an approach last seen during the reign of the Stationers' Company in England over three hundred years ago. Once established, the Stationers' Coinpany's monopoly lasted 138 years. With history as a lesson, we can only

${ }^{204}$ Lardner, supra note 31, at 229; see also Home Recording Hearings, supra note 205 , at 142 ("Unless we do something to insure that the creators of the material are not exploited by the electronics revolution, that same revolution which will make it possible for almost every household to have an audio and video recorder will surely undermine, cripple, and eventually wash away the very industries on which it feeds....") (statement of Howard Oliver, Executive Secretary, American Federation of Television and Radio Artists). 
hope that the new guild monopoly created by the DMCA will not hold sway so long. 